
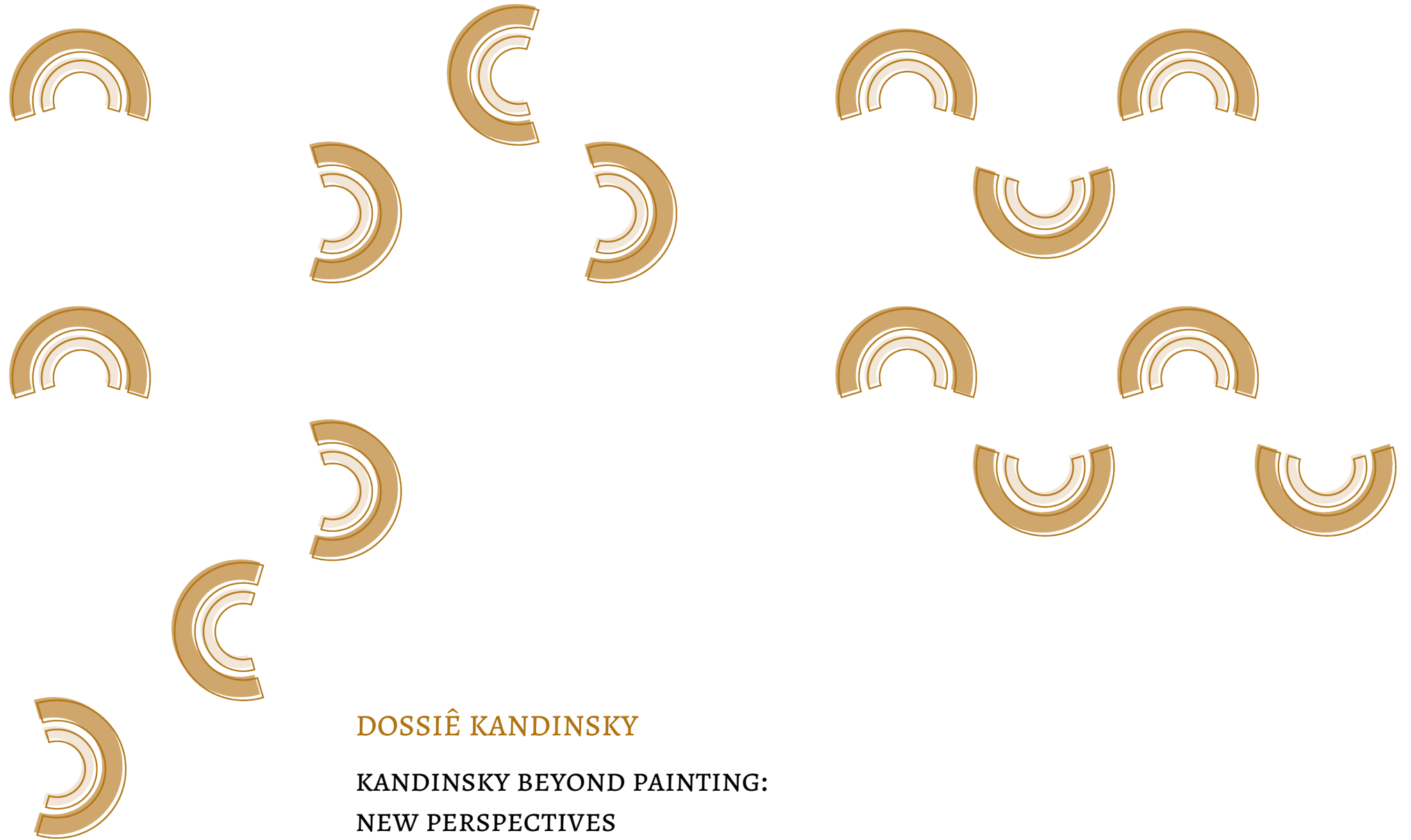

DOSSIÊ KANDINSKY

KANDINSKY BEYOND PAINTING:

NEW PERSPECTIVES

Guest Editor

DOI: https://doi.org/10.26512/dramaturgias.voi9.24910 


\section{INTRODUCTION}

This Special Issue on Kandinsky is dedicated to exchanges between Theatre and Music, artists and researchers, practitioners and close observers. The Contents were also selected to interest and surprise the general public's multitudes of Kandinsky aficionados. Since Dr. Marcus Mota's invitation in 2017, I have been gathering scholarly, professional, and other thoughtful writings, to make of the issue a lively, expansive, and challenging inquiry into Kandinsky's works, activities, and thinking - especially those beyond painting.

"Especially those beyond painting." Indeed, the conceit of this issue, Kandinsky Beyond Painting, is that there is more than enough of Kandinsky's life in art for discussion in the fields of Theatre, Poetry, Music, Dance and Architecture, without even broaching the field he is best known for working in. You will find a wide-ranging collection of essays and articles organized under these headings.

Over the years, Kandinsky studies have thrived under the care of a tightknit group of intrepid scholars who publish and confer. But Kandinsky seems to me to be everywhere. In my reading, for example, his name appears unexpectedly in books on a wide range of topics: philosophy, popular science, physics, neuroscience, history, Asian studies, in personal memoirs of people in far-flung places, and more. Then, too, I know more than a few people who are not currently scholars or publishing authors evoking Kandinsky's name, but who nevertheless have important Further Perspectives, being among the most interesting thinkers on Kandinsky, having dedicated much rumination to the deeper meanings of his life and work. You will find remarkable entries under this heading. 
As we all know, the Internet is a curse and a blessing. On the one hand, non-specialists and specialists alike have spread a narrow version of Kandinsky, rife with misinformation, some of it scurrilous. Did he play the violin, break with his parents on becoming an artist, was he a devotee of theosophy, was he anti-Semitic, was he tragically isolated in Paris? No; all no. On the other hand, the Internet allows us access to rich Materials and Links, even global ones, we could not otherwise see: documents, articles, videos, visual resources. You will find an unusual selection of these under this heading.

It is ironic that Kandinsky's work is divided here into separate sections in order to talk about his nothing-if-not-interdisciplinary preoccupations in the arts. And, for example, which section does his much cited music-paintingdance experiment go into? This kind of quandary persisted throughout the development of this Special Issue and, as a result, you may find some hybrid material under headings where you might not expect them, and some overlapping of content.

Also ironic: those of us here to shed light on Kandinsky's interdisciplinary thinking nevertheless write about that thinking in the respective vocabularies of our separate fields. Essays referring to his mysterious, idiosyncratic stage concoction The Yellow Sound are a case in point. You will see that in Theatre, it is a "play" or a "script"; in the Music section, this piece is called an "opera"; in Dance, the same piece is a "ballet." Contributors who are art historians call it a "composition" — as indeed (along with the word "construction") Kandinsky himself largely did - the same word he used for some of his crucially important paintings.

From my perspective as a theatre practitioner and scholar as well as an art historian, it is a further irony that Kandinsky's stage-related work receives more attention from outside the field of theatre than in it. More than anything, this speaks to the theatre's historically fitful relationship with its avant-garde. Kandinsky's contributions to the stage are every bit as revolutionary as his contributions to painting, but have never been seriously mined for their treasures. Note that Kandinsky was well read in both classical and contemporary dramatic literature (Goethe, Kleist, Ibsen, Chekhov, Maeterlinck, et alia), and well aware of experimenters of his time, such as Isadora Duncan, Dalcroze, Volkonsky, and far beyond. His messages to the theatre still await the level of legitimacy from the theatre that they receive in this issue. 
All re-constructions of history are connect-the-dots endeavors. In Kandinsky's history, some connectable dots are missing altogether; some "dots," pieces of information or contexts, are still hidden or passed over - matters without which the true picture of his life and work remains partial.

Dr. Jelena Hahl-Fontaine (formerly Hahl-Koch) has connected more "dots" than any other Kandinsky scholar. Kandinsky's involvements in art, music, theatre, dance, writing; his historical context, personal life, travels and thinking - all find their right place under her charming, multi-lingual, fearless scrutiny. I have revered her work since the 1980s, flying to her lectures and amassing a library of her books and articles. For me, her willingness to contribute to my Contents is a marvelous part of the story of this Special Kandinsky Beyond Painting Issue.

Dr. Hahl-Fontaine is also the one who suggested the Moscow conference contributors you see in the Table of Contents. Her suggestion was especially interesting because Kandinsky's years in Russia, from the outbreak of WWI to his joining the German Bauhaus in 1922, have been a somewhat weak link in our knowledge. Compared to information about his time in Germany and France, information about his "Russian Years" has been far less freely available to us. This has gradually changed in the years since the December 1991 dissolution of the Soviet Union. Although the Russian Contributors in this issue know each other in Russia, they are still mostly new to us, and their papers give us an interesting window onto the questions they are asking about where Kandinsky fits into their post-Soviet, Russian arts landscape.

And thereby hangs a tale from my own experience. When I began my doctoral studies of Kandinsky in the early 1980s, Kandinsky was little known inside Russia. To see a stage work of his, it was to Germany I went, to see the re-construction of his Dessau staging of "Pictures at an Exhibition." Materials pertaining to his work and life in Russia - still incomplete today for various reasons - circulated tenderly among devotees, in hit-or-miss translations, sometimes at great expense or arriving in the mailbox in dog-eared photocopies from distant countries. Russian speakers in the West were luckier, but for the rest of us, by expanding one's search farther and farther afield, one could collect quite an impressive amount of clandestine documentation. Then in Moscow, in January of 1991, I saw one of the first exhibitions of the avant-garde artists who had fallen foul of official ideology after the 1917 Revolution, and whose work - including Kandinsky's - had been thereafter unknown in Russia.

On that same 1991 trip, with my translator in tow, I knocked on the door of Kandinsky's Moscow apartment and was greeted by a quite ordinary tenant who claimed not to know Kandinsky's name. On the way down the stairs, to 
my astonishment I could see where someone had tentatively removed a small area of paint on the wall, below eye level and partly obscured by a hand railing, exposing what was clearly Kandinsky's folk-style decorative painting underneath. It took several more years before the word was out, and there were efforts made to preserve that same painted wall and others on the stairwell, as well as to add to the building's exterior a beautiful plaque stating that Kandinsky had lived there.

By 2010, when I gave a talk on Kandinsky's theatre works and poetry at the St. Petersburg State Theatre Arts Academy (now the Russian State Institute of Performing Arts), the difference was palpable. My audience was hearing the information for the first time, but afterwards, there was eager discussion, and an invitation to give an impromptu class on Kandinsky's spatial analysis for directors and actors in the Advanced Directing Studio. Where Kandinsky is concerned, certainly we are now collectively in a different era of understanding than we were in the 1980 s or ' 90 s.

I also want to direct your attention to parts of this larger publication, Dramaturgies, which is hosting this Kandinsky Beyond Painting issue. Word is that Brazil is currently among the great creative centers of the world, and composer Marcus Mota must be one of the reasons. Please see his orchestrations, composed for Kandinsky's paintings. Anabela Mendes, eminent Kandinsky scholar of Portugal, has also translated Kandinsky's poems and plays from the original German.

In conclusion, I would like to thank the Contributors. In particular, Clay Gold stayed with the project from the first day to the last. Everyone else I haven't yet mentioned also communicated with me across time zones, re-working drafts and keeping to deadlines while traveling, through emergencies, and with difficult schedules. I think together our writings for Kandinsky Beyond Painting: New Perspectives can give the world new perspectives on Kandinsky.

Today, Kandinsky's theatre and related work is the subject of fascination in countries around the world, generating not only conferences, publications, and dissertations, but also exhibits, stage works, collaborations, discussions and friendships. In this Special Issue, the List of Contributors and the Table of Contents are proof that attention is being paid to the full scope of Kandinsky's achievements, in Belgium, Brazil, Canada, China, France, Germany, Nigeria, 
Portugal, Russia, Singapore, the U.K., and the U.S. The issue covers a dynamic spectrum of historical and creative thought, by theoreticians and practitioners, from their 20 s to just shy of 100 years old. That is, the issue is multi-disciplinary, multi-generational, and multi-national. Special indeed.

Wishing you a reading experience as unconventional and adventurous as Kandinsky himself was, in the worlds beyond painting.

Lissa Tyler Renaud

Oakland, California, December 2018

$\odot$

\section{NOTES ON THE EDITING}

I have heavily edited the language in papers received in time from quite a few non-native writers of English, wishing to give readers best access to the ideas therein without intruding on the authors' intentions.

I asked Contributors to guide the reader to sources in the body of their text instead of using citations, and to limit references to unusual or hard-tofind sources. 


\section{LIST OF CONTRIBUTORS}

\section{MARIANNE ACKERMAN}

A long-time Montrealer, Marianne Ackerman has published three novels, two collections of short stories and written more than a dozen plays. She is currently developing a sequel to Triplex Nervosa, which premiered at Montreal's Centaur Theatre in 2015, and is writing a trilogy about the Canadian pioneer writer Susanna Moodie.

www.marianneackerman.com

\section{KIRIL BOLOTNIKOV}

Kiril Bolotnikov has worked on the editorial team of The Shanghai Literary Review and written about the arts for Neocha. Majoring in Global China Studies, he graduated cum laude from New York University's campus in Shanghai, where he still lives and works.

\section{CLAY GOLD}

Clay Gold is a British sound designer and writer living in Canterbury, UK. He has a specific interest in avant-garde theatre and recently co-wrote 'Parallelist', a monodrama for music, tape and a live telephone exchange, with cellist/ singer Laura Moody. 'Parallelist' premièred at Aldeburgh Festival 2017.

www.claygold.co.uk

\section{JELENA HAHL-FONTAINE (formerly Hahl-Koch)}

$\mathrm{PhD}$, Art History and Slavic Studies, Heidelberg. Teaching: Universities of Erlangen-Nurnberg, Bern, State University of Texas, Austin, Louvain-la-Neuve, Belgium. Curator: the Kandinsky-archive, Lenbachhaus, Munich. Publications: Kandinsky/Arnold Schoenberg letters; the monograph, Kandinsky; the Kandinsky Forum I-IV, etc.; also texts on Jawlensky, Sacharoff, Bechtejeff, Russian Avantgarde, etc. Lectured widely: Europe, America, Australia.

\section{ILONA I. KRYMSKAYA}

Ilona Krymskaya recently earned her doctorate in Art History with a dissertation on Kandinsky. She is currently a lecturer at the Vaganova Ballet Academy in St. Petersburg, Russia. She contributed a paper on Kandinsky's The Yellow Sound to the Kandinsky and Theatre-Performance conference in Moscow in 2017. 


\section{MARCUS MOTA}

Marcus Mota is editor in chief of Dramaturgies, journal of the University of Brasilia, where he has been on the faculty of the Performing Arts Department since 1995. Mota did his Ph.D. thesis on Aeschylus and musical dramaturgy. He is a published scholar, playwright and composer. New book published, 2018.

\section{NADIA PODZEMSKAIA}

Research fellow, CNRS (CRAL, Paris), educated as a philologist and painter. Her research: on the writings of artists and their publishing and interpretation. She has been largely working and publishing on Kandinsky and on the theory and history of art in Russia in the first two decades of the 2oth century. podzemsk@ehess.fr

\section{IRINA SIROTKINA}

Researcher, Vavilov Institute for the History of Science and Technology, Russian Academy of Sciences, Moscow. Diagnosing Literary Genius: A Cultural History of Psychiatry in Russia, 1880-1930 (Johns Hopkins UP, 2002); The Sixth Sense of the Avant-Garde: Dance, Kinaesthesia and the Arts in Revolutionary Russia (Bloomsbury Methuen Drama, 2017).

\section{LISSA TYLER RENAUD}

Ph.D. (U.C. Berkeley, 1987): dissertation, Kandinsky's theatre work. Founded InterArts Training (1985-) to train actors based on Kandinsky's teachings. She has taught, lectured, and published widely — as visiting professor, master teacher, invited speaker, actor-scholar — throughout the U.S.; at major theatre institutions of Asia; in England, Mexico, Sweden and Russia.

\section{PETER SELZ}

Ph.D. U. Chicago. Professor, Institute of Design. Chief Curator, Painting and Sculpture, Museum of Modern Art, New York, 1958-1965. Founder-Director, Berkeley Art Museum, 1965-1973. Professor, Art History, U.C. Berkeley, 19651988. Publications: countless reviews, articles. 15 books: 20th Century Art, from German Expressionist Painting (1957) to The Art of Engagement (2005).

\section{BORIS SOKOLOV}

Professor, Russian State University for the Humanities (Moscow). Has been researching Vassily Kandinsky since 1993: the artist's multicultural background, theatrical texts and poetry. Sokolov has published a large book, Vassily Kandinsky. 
The Epoch of Great Spirituality - Painting, Poetry, Theater, Personality (2016), and the Russian version of Kandinsky's album Sounds.

\section{LEE EDGAR TYLER}

Author and teacher of distinction. Bilingual German/English. Until recently, Associate Professor of English, director of Global Studies Program, Baton Rouge Community College. Served on the editorial staffs of The Missouri Review and Chariton Review, and is a former managing editor of the scholarly journal Oral Tradition. Special interest in Dance.

\section{GIOVANNI VINCIGUERRA}

Giovanni Vinciguerrra was the initiator and stage designer of the theatrical production Planet Kandinsky (Moscow, 2017). He was born in Paris. He studied stage design and set construction at the Moscow Art Theatre School. He currently studies Ancient Greek and Latin at the Freie University, Berlin.

\section{DAVID WILEY}

Painter-poet: graduate of U. Kansas; studied in Mexico and with artist Ignacio Belen in Barcelona. Widely traveled, he exhibits and, since 2005, receives mural commissions throughout California, Arizona, Mexico and abroad. Wiley has published two volumes of poetry: Designs for a Utopian Zoo (1992) and The Face of Creation (1996).

\section{ELIJAH WILLIAMS}

Recipient of the Peter Hoyt Berg Scholarship for Design; Cal Poly Architecture Launch Pad Best In Show, Honorable Mention; Member of Hearst Foundation Lecture Committee; Research Resident with Young \& Ayata in NY; Shortlisted for Odo Prize for Integrated Design; Co-Author of Survey of Architectural Greebles with Jeremy Magner.

eliwilliams1337@gmail.com

\section{ROSS WOLFE}

Ross Wolfe is a writer, historian, and architecture critic living in New York. His interests range anywhere from Marxism to the modern movement. He blogs semi-regularly at The Charnel House and has written for a variety of publications, including e-flux, Radical Philosophy, Situations, and LARB.

\section{ZARINA ZABRISKY}

An award-winning American author of five books published internationally. She holds an M.A. in Literature from St. Petersburg University, Russia. Her 
work has been featured worldwide in over fifty magazines, has won a 2013 Acker Award for Achievement in the Avant-Garde, and been nominated for the Pushcart Prize three times. 


\section{TABLE OF CONTENTS}

INTRODUCTION

Lissa Tyler Renaud

\section{A. THEATRE}

1. Kandinsky in the Theatre World: A Narrative Overview

Lissa Tyler Renaud

2. Kandinsky: Writings Towards the Theatre of Synthesis

Lissa Tyler Renaud

3. Materials in a Spiritual World: a contextual look at The Yellow Sound

Clay Gold

\section{Memories of a Very Early Witness}

Jelena Hahl-Fontaine

5. Versions of the Text of The Yellow Sound

llona I. Krymskaya

6. Review: "Avant-garde theatre shows its age with Bauhaus Violet" Marianne Ackerman

7. Kandinsky Experience: From Pictures at an Exhibition to Planet Kandinsky Giovanni Vinciguerra

8. International Conference, "Kandinsky and Theater-Performance," Moscow 2017: Dialogues with Charlotte Beaufort, Sergei Lobankov and Anna Konstantinova Nadia Podzemskaia

\section{The Yellow Sound: Mackievičius 'pro and contra' Kandinsky}

Anna Konstantinova

\section{B. POETRY}

1. Kandinsky's Theater of the Word: From Sounds to Violet

Boris Sokolov 
C. MUSIC

1. L'abstraction et l'atonalité. L'amitié de Kandinsky et Schoenberg

Jelena Hahl-Fontaine

2. Russian Portfolio: Three on Kandinsky and Music

2.1 Kandinsky and the Language of Music

Nadia Podzemskaia

2.2 The Music of Kandinsky's Theatre Experiments

Nina Sviridovskaya

2.3 The Color Music of Aleksandra Unkovskaya

Elena Scherbakova

3. The Dramaturgy and Multisensoriality of Kandinsky: The Audioscenes

Project

Marcus Mota

D. DANCE

1. Bewegung/Tanz

Jelena Hahl-Fontaine

2. Kandinsky and Dance Photographs: Applying a Comparatist Methodology Lee Edgar Tyler

3. Kandinsky and the New Dance

Irina Sirotkina

E. ARCHITECTURE

1. Kandinsky and Architecture

Ross Wolfe

2.The Spiritual in Art and Architecture: Notes for a New Context

Elijah Williams

\section{F. FURTHER PERSPECTIVES}

1. On Kandinsky: Lissa Tyler Renaud Interviews Art Historian Peter Selz

Lissa Tyler Renaud, Peter Selz

2. Kandinsky and the Totalitarian State

Zarina Zabrisky 
3.The Bauhaus as Inspiration for Chinese Innovation: Report from Hangzhou, China

Kiril Bolotnikov

\section{Considering Kandinsky's Circles: A Painter's Adventure of the Mind}

David Wiley, Lissa Tyler Renaud

G. MATERIALS AND LINKS PORTFOLIO

Selected by Lissa Tyler Renaud

\section{Painting and Acting; Architecture and Fashion}

1. Helen Mirren on Vasily Kandinsky and Acting (Transcript and Link)

2. Nigeria: Bauhaus Architecture and Kandinsky Fashion (Introductions, Links)

\section{Theatre and Poetry}

3. The Yellow Sound: An unstageable composition? Technology, modernism and spaces that should-not-be (Link)

4. Between Text and Image in Kandinsky's Oeuvre: A Consideration of the Album Sounds (Link)

\section{Kandinsky in Contemporary Performance}

5. Dance (Belgium), Theatre (Singapore), Installation (Berlin), Ballet (Bavaria) [Links] 


\title{
A. THEATRE
}

\section{KANDINSIKY IN THE THEATRE WORLD: A NARRATIVE OVERVIEW}

Lissa Tyler Renaud

\begin{abstract}
In his day, Kandinsky's theories of dramatic art and his plays were hailed by theatrical innovators such as Hugo Ball and Oskar Schlemmer, and brought him into contact with important theatrical figures such as Massine, Diaghilev, Stanislavsky, and Breton. A missing link between traditional and experimental values in the theatre.
\end{abstract}

Keywords: Kandinsky. Experimental theatre.

\section{RESUMO}

Quando de sua veiculação, as teorias dramáticas e as peças de Kandinsky foram aclamadas por inovadores das artes da cena como Hugo Ball e Oskar Schlemmer, colocando-o em contato com figuras relevantes do teatro como Massine, Diaghilev, Stanislavsky, e Breton. Disto, irrompe como um elo perdido entre valores tradicionais e experimentais no teatro.

Palavras-chave: Kandinsky, Theatro Experimental.

$\odot$

\section{NOTES ON THE TEXT}

What follows is excerpted from the Introduction to my 1987 doctoral dissertation, entitled Kandinsky: Dramatist, Dramaturg and Demiurge of the Theatre. The text below has lived many lives since then, in lectures and rehearsal halls. Beyond a tidbit here or there, it has been tempting to make additions and other adjustments to it, but I find there is more than enough still-unfamiliar material in it as it is. It is also of some historical interest to get a feel for the breadth and depth of information that could be pieced together after Kandinsky's death in 1944, especially in the 1970s and 1980s when the avant-garde burst into a period of flourishing.

No significant adjustments, that is, with one exception. Full appreciation of Kandinsky's theatre work has been hobbled by faulty translation of the critical adjective "synthetic." The evocative noun "synthesis" and verb "synthesize" 
refer to melding, unifying, blending, or fusing. But in a quirk of English usage, "synthetic" means inauthentic, fake, imitative - so that translation references to Kandinsky's "synthetic theatre," to be carried out by the "synthetic artist," are puzzling or even off-putting.

Finding an alternative is challenging. Over the decades, I have used these phrases, wincing, to keep my work aligned with usage in the field. In the 1980 s we used the term "interdisciplinary theatre," and today we talk about "fusion theatre," which is perhaps closest to Kandinsky's sense of many becoming one. Either of these gets somewhat at the inclusive spirit of Kandinsky's theatre. In any case, hereby breaking with the past, except in direct quotations, in the following text I have avoided the word "synthetic" while staying close to the original word and meaning.

Kandinsky's life was a process of bringing unity to sprawling, complex elements. He was a Russian who lived primarily in Germany, then spent the last years of his life in Paris. At the opening of his career in Germany and at the close of it in France he was considered a Russian artist, whereas his compatriots identified him with the romanticism and subjectivity of the German art scene. He held citizenship papers in each of these countries at different times, speaking each of their languages. He traveled in many more countries than he lived in, and studied still more. Ultimately, even when he had a choice, both as an artist and a person he claimed the right to be a true "world citizen."

In addition to the sensibilities that he culled from around the world, Kandinsky's work unified his various areas of training and interest. He was armored as a critic and organizer by professional training in law and economics. He was supported as a teacher of "the science of art" by the methods of systematic inquiry required by ethnographic work he did as a university student. As a painter, he learned anatomical drawing and color theory from one teacher, Anton Ažbè, and the flow of forms from another, Franz [von] Stuck, blending these two influences into an art that extended beyond the realms of both.

Kandinsky also sought a way to unify - to "synthesize" - his other interests. He was an accomplished amateur on the piano and the cello. He wrote poetry. At the turn of the century he sketched period peasant costumes, and designed dresses, embroidered purses and hangings, and jewelry. At various times during his life he also designed wall murals, furniture, vases, and dishes. These interests in the sets, costumes and props of everyday life, as well as in 
music, poetry and the dramatic impact of a visual image, reveal a temperament that one recognizes might find satisfaction in the theatre.

Indeed it was to the theatre that Kandinsky turned for a place to synthesize his experiences and abilities. Over a period of 35 years, in Germany, Russia and France, as dramaturg, dramatist and self-appointed demiurge of the art world, Kandinsky pursued his elusive, monumental vision, the Synthesizing or Unified Art of the Stage.

When Kandinsky came to Munich from Moscow to study painting in 1896 at the age of 30 , he had already been convinced of the power of the theatre by a production he had seen of Wagner's Lohengrin. Perhaps because of this conviction, his activities in Munich brought him into contact with many people who were involved in performance. In 1900 he co-founded Phalanx, an association of young artists who exhibited their works together. One member of this group was Alexander von Salzmann, who later engineered the revolutionary lighting designed by Adolphe Appia for Jacques-Dalcroze's School at Hellerau. Peter Behrens both exhibited with Phalanx and played an influential role in Munich's experimental theatre circles. Behrens worked closely with Georg Fuchs, the great theatre reformer, who was also to become more than tangentially associated with Kandinsky a few years later.

Other members of Kandinsky's society were concurrently involved with a group of avant-garde cabaret performers called Eleven Executioners (Elf Scharfrichter). One was a sculptor named Husgen, who designed masks. Another was Ernst Stern, who designed the group's sets and posters, and who eventually designed for Max Reinhardt's theatre in Berlin. It is interesting to note that two other members of the cabaret group were the playwright Frank Wedekind, who sang, and Reinhard Piper, who was to become Kandinsky's publisher. The Phalanx association continued through 1904.

In 1902, Kandinsky wrote some art correspondence for a journal that was edited by Diaghilev called The World of Art. In this context, Kandinsky came close to knowing more of Chekhov than just his plays; Chekhov's letters include one to Diaghilev in 1903, in which he refused Diaghilev's invitation to become editor of the journal. Although the art correspondence was his only writing for Diaghilev, Kandinsky followed the publication closely, and surely knew Diaghilev's work in the theatre. Aside from the fact of Diaghilev's prominence in the Russian avant-garde, Kandinsky took an interest in the work of Leon Bakst, who was a painter as well as both set and costume designer for Diaghilev. Later events would also involve Kandinsky directly with Fokine, Diaghilev's great choreographer.

In 1908, Kandinsky was already thinking about writing for the stage. In 1909 he met Thomas von Hartmann, a young Russian composer who was 
studying in Munich. Hartmann wrote later that Kandinsky was dissatisfied with the theatre in general, and the opera in particular, from 1909; in any case, they began to experiment together.

Their first idea was to stage one of Andersen's fairy tales. Often the two of them worked through their ideas with Hartmann improvising at the piano as Kandinsky described what was happening on the stage. Kandinsky sketched a medieval set for the fairy tale, and the text that they created is apparently the same manuscript called Paradise Garden that was found among his papers. We might wonder whether the sensation that Diaghilev's Ballet Russe created in Paris that same year, which also featured one of Bakst's sets, might not have encouraged Kandinsky and Hartmann to set their sights higher; after experimenting with translating their fairy tale into a ballet, they discarded the idea and started again.

At this time, a Russian dancer named Alexander Sakharoff joined the collaboration. As in any true collaborative effort, it was necessary for them to know something of one another's creative disciplines, and already having some understanding of music in common, Hartmann and Kandinsky set out to learn about dance, starting with ancient Greek dance, while Sakharoff studied the paintings in the museums. In this way, the next project they approached was a staging of Daphnis and Chloe, for which Kandinsky again sketched a set for the opening scene, "a marvelous trireme with warriors [which was] by no means a realistic picture, but it conveyed an astoundingly strong impression of Daphnis' terror."

The association of Kandinsky, Hartmann and Sakharoff led to a series of often-referenced experiments in which they tried to discover the ways in which their respective arts informed one another:

From among several of my watercolors the musician would choose one that appeared to him to have the clearest musical form. In the absence of the dancer, he would play this watercolor. Then the dancer would appear, and having been played this musical composition, he would dance it and then find the watercolor he had danced.

Kandinsky believed that whatever the three of them found by studying together would not only prove the inter-relatedness of their arts, but that in fact he could also learn something about painting by pitting himself against different disciplines. Twenty years later he wrote: "It is more profitable for an artist to acquire specialist knowledge of some unfamiliar subject, provided he is able to develop the... capacity for analytical-synthetic thought, than to be narrowly 'educated' in his own subject." 
Kandinsky wrote four plays in the years 1908-9. These were Stage Composition I, Voices, which came to be retitled Green Sound; Giants, which was revised and retitled Yellow Sound in March of 1909; Stage Composition III, Black and White; and Stage Composition IV, Black Figure.

The opening of Georg Fuchs' Munich Artists' Theater in early 1908 may have given some impetus to Kandinsky's stage projects. There is no doubt that Kandinsky knew Fuchs' writings on innovative theatre, which bear much relation to both Appia's and Craig's ideas; Fuchs' work was the talk of Munich art circles, and two of Fuchs' articles even appeared in the same journal, Apollon, to which Kandinsky contributed art reviews in 1909-10. Kandinsky's own writings on the theatre resemble some of Fuchs', but we will never know whether Fuchs actually influenced Kandinsky, or just corroborated what he already felt to be true. Having collected his ideas for as many as twelve years, Kandinsky finished writing his first book, On the Spiritual in Art in 1910. It was published the following year. This early book already contained a discussion of "new dance," with reference made to Isadora Duncan's work; it also introduced the principles of "the theater of the future" that Kandinsky would invoke for the rest of his life.

Of all of the plays Kandinsky had written, he singled out Yellow Sound to work on over the longest period of time. He finished it in 1912, and published it the same year in the Blue Rider Almanac, which he edited with his great friend, the painter Franz Marc. The text of the stage composition is preceded by a full essay, "On Stage Composition." In it, Kandinsky discusses his theories of dramatic art at some length, particularly articulating the distance between his own conception and Wagner's.

In 1913 Kandinsky planned to illustrate the Bible with, among others, Franz Marc, Paul Klee and the Expressionist painter and playwright, Oskar Kokoschka. In the first year of his correspondence with Schoenberg (1911), Kandinsky had already asked about news of Kokoschka several times, and had mentioned having seen his paintings three years earlier, that is, when Kokoschka first began to exhibit. 1913 was also the year that Kandinsky's autobiographical Reminiscences appeared; it included a description of his pivotal encounter with Wagnerian theatre. Sounds, an awe-inspiring volume of thirty-eight prose poems was also published, and remains to this day an incomprehensibly hidden treasure of modern literature.

Hugo Ball and Kandinsky had met in 1912 when Ball came to the Munich Artists' Theater as dramaturg after studying and teaching in Max Reinhardt's drama school. In early 1914, Kandinsky introduced Ball to Hartmann, who had just taken Kandinsky's script and set designs for Yellow Sound, along with 
his own music, to Stanislavsky at the Moscow Art Theatre in Moscow. Stanislavsky - whose theatre had just been producing Turgenev, Molière, and Goldoni had not shown any interest in it. Ball proposed Kandinsky's Yellow Sound for production at the Munich Artists' Theater. It was intended to be performed with Hartmann's music and Alexander Sakharoff dancing the leading role. During this year, Kandinsky wrote his fifth known stage composition, Violet Curtain, generally known as Violet. One might speculate that the energy for this new play came from the encouragement concerning his earlier script that he received from his peers during this time.

Also in 1914, Ball made plans with Kandinsky, Marc, Hartmann and Fokine for a book to be titled The New Theater. This was to be a sort of Blue Rider Almanac of experimental theatre. Kandinsky was to write an article on the "total work of art," to be included with articles and stage designs by the others. Klee and Kokoschka were to contribute designs and plays respectively. They hoped for this association of artists to expand into an International Society for Art, a society for modern artists of the theatre, painting, music and dance. In a letter to Schoenberg at this time, in anticipation of a visit from him, Kandinsky wrote: "Here there are all sorts of theater plans, which you have already heard about from Marc. You are therefore awaited with particular eagerness." The "eagerness" of this letter makes it all the more heartbreaking that every one of these plans for play production, book, international society - and even Schoenberg's visit - were aborted by the sudden outbreak of World War I. In an odd twist of fate, the resident Kandinsky and the touring Stanislavsky, both in Germany and suddenly now enemy aliens, found themselves arrested together, and then escaped to Switzerland together on the same boat.

When Ball opened the Cabaret Voltaire in Zurich, Switzerland in 1916, Kandinsky's work played a part. The second night of the Cabaret featured Kandinsky's poems and a song by Wedekind. These Dada evenings included the works of a fascinating combination of artists: in the following month (March), for example, "two humorous pieces by Chekhov" were performed, and Hans Arp read from Jarry's Ubu when a Lautréamont text did not arrive in time. Debussy, Turgenev and simultaneous poetry were all presented without regard to critical distinctions, as if artists were at peace with one another while the rest of the world was at war. When the Cabaret put out its one journal issue, a poem of Kandinsky's was included.

The Cabaret closed, and the following year Ball and Tristan Tzara opened the Galerie Dada, which had Kandinsky's paintings among those on the walls, and a cafe called the Kandinsky Room. The connection between Kandinsky and early Dada has been virtually ignored by scholars - a great loss to historians 
of theatre, arts and culture. Less than a month after the March opening, Ball's diary shows he offered a lecture on Kandinsky that included this passage:

Kandinsky is one of the great innovators, purifiers of life. The vitality of his intent is astounding and just as extraordinary as Rembrandt's was for his age, as Wagner's also for his, a generation ago. His vitality embraces equally music, dance, drama, and poetry. His significance rests on the fact that his initiative is equally practical and theoretica1. He is the critic of his own work and of his epoch. He is a writer of incomparable verses, creator of a new theatrical style, author of some of the most spiritual books in recent German literature.

The next week, three of Kandinsky's poems were read, and later that night Kokoschka's Sphinx and Strawman was performed, with Hugo Ball and his wife, poet and cabaret artist Emmy Hennings, in the title roles. As late as 1919, as Dada was coming to a close in Zurich, Kandinsky's poems were still a part of the brouhaha.

In the meantime, Kandinsky had had to travel through multiple countries to return to Russia. After the October Revolution of 1917, he was involved in the reorganization of cultural programs under the People's Commissariat of Enlightenment (NKP), which had been created by the Revolutionary government. In 1918, a Department of Visual Arts (IZO) was established under NKP, and Kandinsky was invited to become a member. When a Theater and Film Section was added, Kandinsky was made the director of it. This section published a journal, Visual Arts, of which Kandinsky was named editor. He published his essay "On Stage Composition" from the Blue Rider Almanac in the first issue of the journal.

In 1920 Kandinsky wrote a series of articles for the IZO NKP journal, Artistic Life. In one of them, he urged the creation of an international art congress that would include artists from the fields of painting, sculpture, architecture, music, dance, literature (especially poetry), and "all branches of the theater, including the intimate stage, variety, etc., right up to the circus"; all of these artists would collaborate on the creation of a "monumental art."

When an Institute for Artistic Culture (INKhUK) was established the same year, with Kandinsky at its head, he designed a program for just such a collaborative effort. He presented his program at the First Pan-Russian Conference of Teachers and Students at the State Free Art and Industrial Art Studios, one studio of which he had been teaching since 1918. This program assumes that there is a "science of art." In other words, Kandinsky believed 
that there are synthesizing principles of art that can be taught, and that these principles, in conjunction with the principle of "inner necessity," are the artist's means, his goal in turn being a synthesized or unified art form. While the concept of "inner necessity" is the basis of Kandinsky's originality, this notion of "synthesis" is the crux of his genius. Elsewhere I have written about Kandinsky's training of the synthesizing artist, "synthesis" being the second of Kandinsky's great guiding principles.

Six months later, in December of 1920, he delivered a report to the first Pan-Russian Conference, a meeting of all of the heads of art sections under NKP. In his report he stated that his Institute was founded "for the purpose of studying ... synthetic [unified] art," and gave as an example the early watercolor/music/dance experiments he had done with Hartmann and Sakharoff in Munich. However, Kandinsky's program was not accepted by his colleagues within the Institute itself, and he resigned shortly thereafter. He adapted part of the program a few months later for the Russian Academy of Artistic Sciences. There, he was chairman of a subcommittee on "physio-psychology" and the visual arts. This time the plan was accepted, but it was not carried out because Kandinsky returned to Germany before the end of the year.

That year, 1922, the Popular Theatre in Berlin offered to produce Kandinsky's Yellow Sound. We can gain some insight into how seriously Kandinsky took his collaborative conception of the theatre: he turned down this opportunity because Thomas von Hartmann was unavailable to work on the music with him. In 1923, a theatre article by Kandinsky entitled "Abstract Synthesis on the Stage" was published at the Bauhaus, where he had accepted a teaching job. True to the spirit of the school's architectural emphasis, this short article takes off from a discussion of the relationship between the audience and the architecture of the theatre building itself, and concludes with the briefest summary of the "theater laboratory" program he had envisioned while still in Russia.

In 1926 Kandinsky published another article, "Dance Curves: The Dances of Palucca," in which he did an extraordinary analysis of the choreography of this German dancer, Gret Palucca. He also dealt with her work again in his major book Point and Line to Plane of the same year.

1927 saw two publications of Kandinsky's theatre-related writings. The first was "And, Some Remarks on Synthetic [Unified or Fusion] Art," which, the casual implication of the word "remarks" notwithstanding, includes a historical analysis of the gradual separation of the arts and suggests possibilities for their reunion, as always, in the theatre. The second publication was an excerpt from his play, Violet, written thirteen years earlier. Oskar Schlemmer, who edited the issue of the Bauhaus journal in which Violet appeared, was also 
responsible for the famous theatre experiments of the Bauhaus Stage Workshop. At some point Schlemmer also became interested in producing Yellow Sound; Kandinsky wrote wistfully in a letter of 1937, "[b]ut once again it didn't work out... Such things have their own destinies." In fact, we can see in the Prospectus for the Bauhaus Books that publication of the text of Violet in its entirety was also announced by the Bauhaus, but it, too, "didn't work out."

The next project did. In 1928, Kandinsky accepted an invitation by the Friedrich-Theater in Dessau to stage Mussourgsky's Pictures at an Exhibition. Finally, after twenty years of writing plays and theoretical articles for the theatre, as well as experimenting and lecturing on its behalf, Kandinsky brought his creative imagination to bear in actual theatrical production. And he did so with a conception of such brilliance and sophistication that it boggles the mind to think of what he might have accomplished if his life had not spanned the two world wars which uprooted him in one way or another for most of his adult life.

Kandinsky designed all sets and lighting for the piece, along with a complex array of props which were suspended above the stage, and which also moved. In two of the sixteen scenes he devised from the music, he also used dancers, and also designed their costumes. Felix Klee, the son of Paul Klee (who was also teaching at the Bauhaus), was a stage manager and production assistant at the theatre. The original of the prompt book that he kept is now at the Pompidou Center in Paris: it includes the musical score with all lighting and fly cues for backdrops and props, as well as his later notations for the choreography.

In 1930 Kandinsky published a brief description of his approach to this project. The structure of the music suggested the shape of each scene, and he translated each of his images from the music into form, color and light, taking into account "of course," he wrote disarmingly, "the necessity of dismantling it." Pictures of sets, costumes, props and prompt book all show his understanding of this practical matter of theatre production.

After his death, Kandinsky's wife Nina wrote in her tribute to him, "The Living Kandinsky," "The Friedrich Theatre where Dr. Hartmann was manager became a kind of studio for Kandinsky, an extension of his own, in which his forms and colors came to life in a new space. Kandinsky the magician, the creator of [fairylands], brought his spell here; he gave life to these creatures of an evening."

More of Kandinsky's wonderfully performable poetry appeared in the important experimental journal transition in 1932. In 1933, after years of precarious standing, the Bauhaus was closed by the Nazis for the last time and Kandinsky, uprooted again, moved to Paris, already in his late 60s. Here 
he received visits from Marcel Duchamp, who had also come to see him at the Bauhaus in 1929, and from Andre Breton. He owned books that were personally inscribed by Breton (Second Surrealist Manifesto), Tristan Tzara and Marinetti. His longtime reservations about Futurism notwithstanding, in 1932 he had written to Marinetti for a letter of support for the Bauhaus, which was, as usual, under threat of closure, and which in fact closed the next year. He attended the Futurist conference of 1935. Four more of his poems were published in transition in 1938, and artist Sophie Taeuber-Arp included three of his poems in her journal, Plastique, in 1939.

Scholars refer in passing to two theatre projects in the last years of Kandinsky's life. In 1939 he is said to have discussed a "proposed multimedia ballet with Leonide Massine. Massine had choreographed Diaghilev's original "Parade" production of 1917, a collaboration that had involved Cocteau, Satie and Picasso. In March of 1944, Kandinsky became ill, but that same month he worked on the scenery for a ballet he planned to produce with Thomas von Hartmann, the same composer with whom he had collaborated on his very first theatre projects in Munich thirty-five years earlier. He stopped working altogether in June, and died in December.

Kandinsky left behind a body of theatre-related work that has never received the serious appraisal it deserves. As we have seen, his collaborators and publishers, as well as many theatre innovators of his day were not so nonchalant about his achievements. Even after his death, in a New York lecture of 1950, Thomas von Hartmann reminded his audience that Kandinsky was a theatre artist, calling Yellow Sound "the greatest venture of stage art to this day." With such votes of confidence from his contemporaries, the theatre of today would benefit from giving Kandinsky's contributions some consideration.

Kandinsky's wife of twenty-seven years, Nina, wrote in her 1976 memoir that her husband's "greatest ambition was to create a large-scale, multi-media ballet." Although the opportunity was never granted him to realize his monumental, synthesizing stage art, he left theoretical writings ample enough to guide us towards his conception, and outlined a method of training for the theatre artist that is so fresh that the contemporary theatre cannot afford to ignore it. These writings themselves must stand in place of the performances that Kandinsky never achieved, and as his audience, he asked us to complete them in our imaginations. 
Lissa Tyler Renaud

\begin{abstract}
The painter Kandinsky wrote about the theatre, and for the theatre, between at least 1908 and 1928. These writings can be loosely grouped: 1 . Theoretical writings, 2. Plays, and 3. Theatre training reform and programs.
\end{abstract}

Keywords: Kandinsky. Theatre Writings. Plays.

\title{
RESUMO
}

O pintor W.Kandinsky escreveu tanto teatro quanto para o teatro entre 1908 e 1928. Estes escritos por ser assim agrupados: 1. Escritos teóricos; 2. Textos cênicos; 3. Treinamento para atores e programas.

Palavras-chave: Kandinsky. Escritos sobre Teatro. Dramaturgia.

○

\section{INTRODUCTION}

Everybody knows that Kandinsky was a painter. Many people have heard that Kandinsky painted the earliest abstract painting. Some people have a vague idea that his work had something to do with spirituality. A few people know he did more than just paint, or that he wrote a book about art. But not nearly enough people have had the pleasure of knowing Kandinsky's wonderful writings for the theatre.

Kandinsky wrote about the theatre, and for the theatre, between 1908 and 1928. These writings can be loosely grouped: 1. Theoretical writings, 2. Plays, and 3. Theatre training reform and programs. His evocative, often dramatic poetry was published between 1912 and 1939. Since his death in 1944, his theatre work in particular has been neglected by the theatre world. He led a nomadic "life in art," spanning World War I, the Russian Revolution and World War II: sadly, this means that relevant documentation was lost, and close colleagues were scattered across the globe or did not survive.

But during his lifetime, Kandinsky's collaborators and publishers, and many theatrical innovators of the time, knew Kandinsky as a profound and original force in the theatre. A few examples: when World War I began, Kandinsky was planning to write a theatre book, and to start a theatre with 
an international group of artists. In Switzerland, Hugo Ball gave a 1917 lecture on Kandinsky at his Dada cabaret, and praised him as "a writer of incomparable verses, the creator of a new theatrical style." In 1918, in Russia, when the People's Commissariat of Enlightenment was forming a Department of Visual Arts [IZO NKP], it published Kandinsky's essay on the theatre, and made him head of a special Theatre and Film Section. In 1929 in Germany, painterchoreographer Oscar Schlemmer asked Kandinsky to take over his position as Head of the famous experimental Bauhaus Theatre.

So: Kandinsky was involved in many interesting theatre-related projects, but here I am going to focus on the writings.

Let me make a few points before I move to those.

Kandinsky's life was a synthesis of disparate elements. He spent important years in Russia, but did his best known work in Germany, and his final work in France. He worked in a broad range of fields: he made historic contributions as a painter, wrote art criticism and taught painting - he also wrote poetry, dramatic theory and plays, and worked for reform in art and theatre education. He also had background in law, economics, and ethnography; he played the piano and cello; at various times he designed clothing and jewelry; wall murals, furniture and dishes. Kandinsky was very aware that this inter-media activity would confuse critics and historians. Towards the end of his life he wrote: “Oh! I remember very well: when I started 'writing poetry,' I knew I would become 'suspect' as a painter... they used to look 'askance' at the painter whenever he wrote - even letters." It was in the theatre that Kandinsky found a place to synthesize his areas of training and interest.

Kandinsky's success as a painter has made him "suspect" as a theatre artist. Art historians tend to consider Kandinsky's theatre work as a painter's experiment, or suggest that he was transferring his painted images from canvas to stage. Kandinsky didn't believe this transfer was possible or desirable. "Each art," he said, "has its own means of expression... and an exact 'translation' of one art to another is impossible. Fortunately." Theatre historians pay little attention to Kandinsky's theatre work, lumping it together with the later "performance art," or what has come to be called "visual theatre." But performance art rejects so many aspects of the traditional theatre that Kandinsky held dear. Critic Michael Kirby observed: "In the [avant-garde] theatre, 'suspension of disbelief is not operative, and the absence of character and situation precludes identification." Kandinsky took a conservative stance towards these fundamental dynamics of the theatre. He was dedicated to the picture stage, and to inviting the audience into a world that was not their own. Kandinsky thought of himself as bringing new life to the conventional stage, not abandoning it. 
Kandinsky's name is associated with the avant-garde movements now, but his ideas about the theatre were already considered old-fashioned in Russia in the 1920's. The co-editors of Kandinsky's English language Complete Writings on Art in 1982 spoke to this in their introduction: "[Kandinsky's art] differs so radically from traditional art that people are inclined to think him altogether estranged from the past. But Kandinsky's writings [correct] this impression by revealing how deeply his thinking... was rooted in European thought and values." True, his conclusions about the theatre are far from conventional, but the stage "revolution" he envisioned had firm roots in the sensibilities of the past.

What follows is the text of a paper I have given in the field of Theatre in the U.S., India, Korea, Russia, Sweden, and China.

\section{PART 1: THE THEORETICAL WRITINGS}

Classical dramatic theory revolves, in

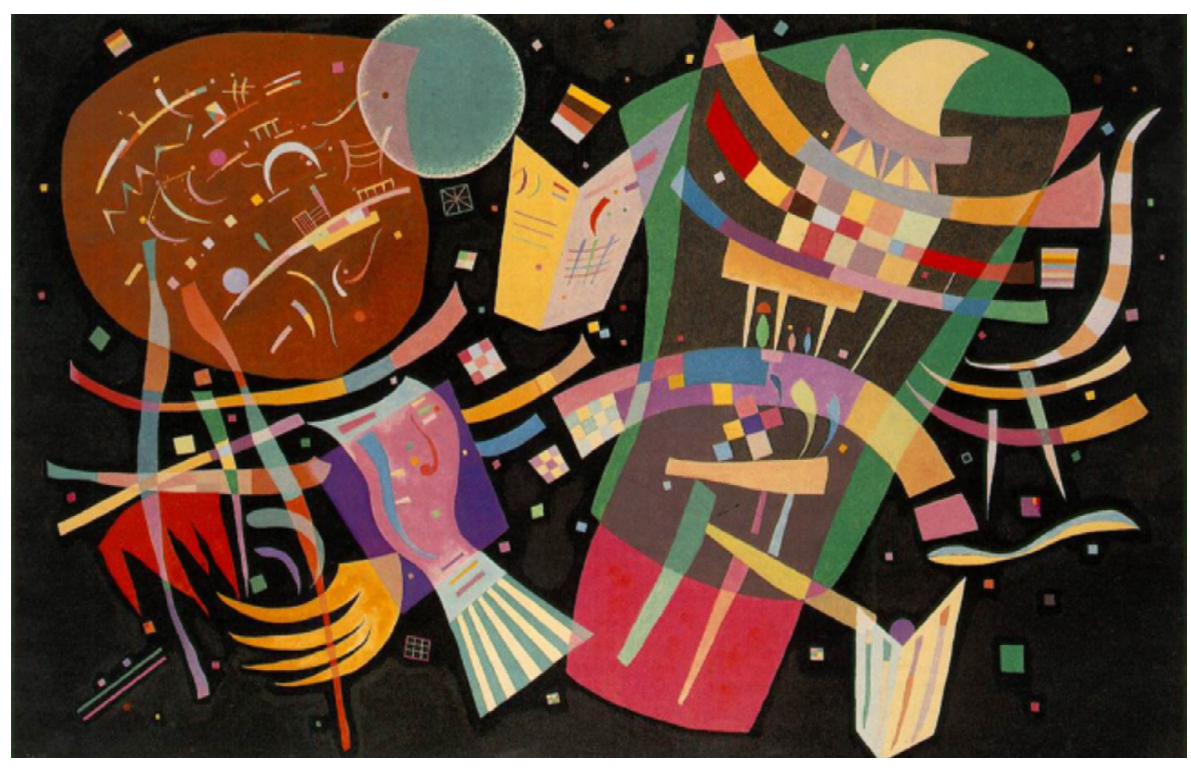

Fig. I “Composition X," 1939. Two festive figures with texts for dramatic or musical performance. medieval theatre served a religious function. Shakespeare created a theatre that celebrated the human imagination; for Racine, the theatre was a laboratory for examining the human core. Other dramatists pivotal to the development of the drama have envisioned theatres that were entertaining, moral, poetic, psychological, anthropological or political.

Kandinsky's theatre reflected elements of all of these to different degrees, but for him, the primary function of all art was spiritual. "Art," he wrote, "[is] that creative force which expands the prison house of our being and allows a vision of eternity..." Kandinsky thought people move through a world so rich in experience, perception and sensation that it was impossible for them to organize all of it. He saw a gap between all of the universal "data" that we can receive, and how much we can fully absorb or digest. Art, then, is a kind of language for systematizing all the intuitive information that ordinarily escapes us. Art translates everything around us into a lexicon, maximizing our experience of the world.

In modern dramatic theory, one of the crucial issues is the changing relationship between language and the visual image. The Industrial Revolution 
brought with it a new world of noise. By the $20^{\text {th }}$ century, the ancient songpoems, the verses of Shakespeare, the cadences of Romanticism no longer expressed the experience of life lived against a soundtrack of the industrial machine, with its superficial rhythms. The sounds of war drowned out the language of words, and in its place, the language of visual images came into a new prominence.

In this jagged new world, Kandinsky's objections to the conventional theatre joined a chorus of complaints: the theatre had become nothing more than an offshoot of the narrative, literary tradition! The poetic tradition was responsible for the withering of all theatrical means except language! The drama was being peeled off the written page, as it were, without being fully translated into a three-dimensional theatrical art!

In this context, Kandinsky devised the theatre he called the Synthetic (Total) or Monumental Art. Although he had agreed with everyone about the theatre's problems, the solutions he found were very different from theirs. Others struggled over which art form should unify the theatrical elements of the new theatre: Wagner thought music should be the primary art form; Appia's primary element was light; Edward Gordon Craig's was scenic composition. Kandinsky's theatre completely sidestepped this discussion. He believed all the arts should be separate and equal — not unified, but distinct languages. Where others looked for parallels between the arts, Kandinsky thought of them in dynamic opposition to one another; where others tried to mirror one art in all the others, Kandinsky wanted to find a contrapuntal relationship between them. The different "grammars" of the art languages, and their common goals, formed the matrix of the "Synthetic" Art - that is, Art by means of Synthesis.

For Kandinsky, the unique power of the theatre is that it synthesizes more languages of expression than other art forms do. In this synthesis, he included everything from the structure of the building to the elements of the performance itself. They work together: the building creates tension and the performance releases it. Imagine this: the drama of the theatrical event begins outside in the street. The theatre building is a magnet that draws the public all the way from outside the building to its powerful center in the inner reaches of the stage. First, the open doors of the building "suck...in streams of people": as unrelated people pass into the lobby, they become related to one another by their common purpose and space: that room unifies them into an "audience." Inside the theatre, the seating area unifies the audience further by organizing them into rows, pointing them all in the same direction, focusing all of their combined receptive attention on a single point: center stage. When the 
theatre structure has concentrated all of this tension to the maximum, the performance begins.

In a charming prose poem from 1912, Kandinsky described the tension as the audience waits for this:

\section{Curtain}

The rope came down and the curtain went up. We had all been waiting so long for this moment. The curtain hung. The curtain hung. The curtain hung. It hung down. Now it's up. As it went up, we were all so overjoyed.

Then, each moment that unfolds on the stage is a small release of tension, and these releases then trigger bigger releases or responses in the audience. In this audience response is the ultimate release of all the powers of all the arts.

\section{PART 2: THE PLAYS}

A brief introduction: Over the years, Kandinsky wrote quite a few informal dialogues, sketches, fragments, and scenarios of varying degrees of experimentation. Some versions are known by different names, and some texts are accompanied by charming, explanatory drawings. The most developed of the early pieces are the three short plays or stage pieces he completed between 1908 and 1909: Green Sound (also known as Voices), Black and White, and Black Figure. At the same time, he began the full-

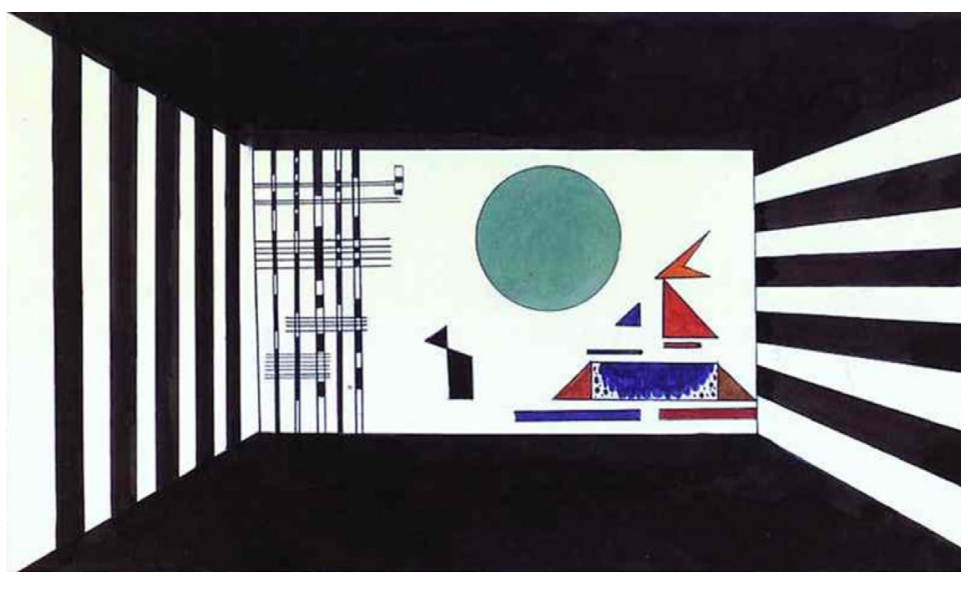
length play entitled Yellow Sound, which he finished and published in Munich in 1912. In 1914, he wrote his longest play (and my favorite), Violet, and what many believe to be an after-piece for it, Apotheosis. A portion of Violet was published in 1927 at the Bauhaus School of Architecture and Design, where he was working. The next year, in Dessau, he created a scenic play of sets, props and lights for Mussourgsky's Pictures at an Exhibition.

Of these plays, people tend to find Yellow Sound the most approachable, perhaps because it was published along with Kandinsky's essay called "On Stage Composition"; there, he explained how he tried to apply his theories of synthesis and counterpoint in Yellow Sound. He was not quite sure it had worked. His final words before the play text began were: "The reader is asked not to ascribe to the principle the weaknesses of the following short composition, Yellow Sound, but to attribute them to the author." In other words, if the play was weak, it was because his skills as a playwright hadn't served his theoretical works about the stage.
Fig. 2 Setting, Kandinsky's stage composition for Mussorgsky's Pictures at an Exhibition, Picture II, “Gnomus," 1928. 
The mood and look of the pieces are easier to communicate than their stories: they have no literary value at all. They seem to take place outside of time, in a world where the environment is at least as active as the figures who live in it. The music and sounds that emanate from the space seem to be in dialogue with hills or trees; light moves, changes color or darkens in reaction to simple gestures. Flowers shudder as if they were human, and people grow as if they were plants. The real protagonists of these plays are the stage elements that usually support the action, and the "characters" are only a part of what scholar Pierre Volboudt called "a cosmic melodrama."

The role of the gods in Greek drama is played here by Nature; but like the gods, the natural world is more forceful than logical. Kandinsky's choruses are similar to the Greek choruses: crowds of barely differentiated figures, dimly grasping at comprehension, perhaps half a step behind the truth. Unlike the classical hero, Kandinsky's hero figures achieve stature mainly due to their calm in the face of fear, confusion and loss. Aristotle's narrative drama attempted to explain the peaks and valleys we experience in our lives. Kandinsky's dramatic synthesis attempted to reveal an inner landscape where everything is an event, nothing can be explained and the real story takes place in some intuitive dimension, invisibly.

Like music, these plays don't tell a story, but they have meaning. Like painting, their form is not linear, but they have structure. Like dance, each piece has statement, development and closure. Like architecture, the plays depend on tensions and counter-tensions. Like sculpture, the plays give shape to volumes in space, and with poetry they share the element of sound in time.

Kandinsky's Yellow Sound fell victim to political instabilities and was never staged while he was alive. It was planned for production in Munich in 1914, in Berlin in 1922 and then at the Bauhaus in 1927. Ten years after this last attempt, Kandinsky wrote wistfully in a letter: "But once again it didn't work out... Such things have their own destinies." But in a New York lecture in 1950, after Kandinsky's death and nearly forty years after he wrote Yellow Sound, the composer Thomas von Hartmann still called Yellow Sound "the greatest venture of stage art to this day."

\section{PART 3: THE THEATRE TRAINING REFORM AND PROGRAMS}

Kandinsky observed that poor arts teaching reinforces the walls between different areas of our experience. In life, for example, our material lives are separated from our non-material or spiritual lives, and this is reflected in training, where the practical aspects of art are taught without wider human values. The sciences are separated from the arts; the arts are separated from one another. Even within the individual arts, painters are divided into "isms," poets into "schools," and actors into "methods." He wrote: 
Nearly the whole of the nineteenth century consisted of a more or less calm process of ordering, categorization, and division.... The astronomer had just as little time for Sanskrit as the musician had for sculpture. On this basis, all possible kinds of colleges were built, which produced highly trained specialists and completely uneducated people. And still do today.

Kandinsky believed that the function of art education is to counteract this divisive approach to both life and art, and provide a broad philosophical basis. The "Synthetic" Art requires the "Synthetic" Artist, and to answer the need for a new kind of education, Kandinsky developed the curricula for two arts training programs.

He developed his first training program in Russia, in the turbulent period following the Revolution. He intended it as a graduate or continuing education program, to give working artists the interdis-
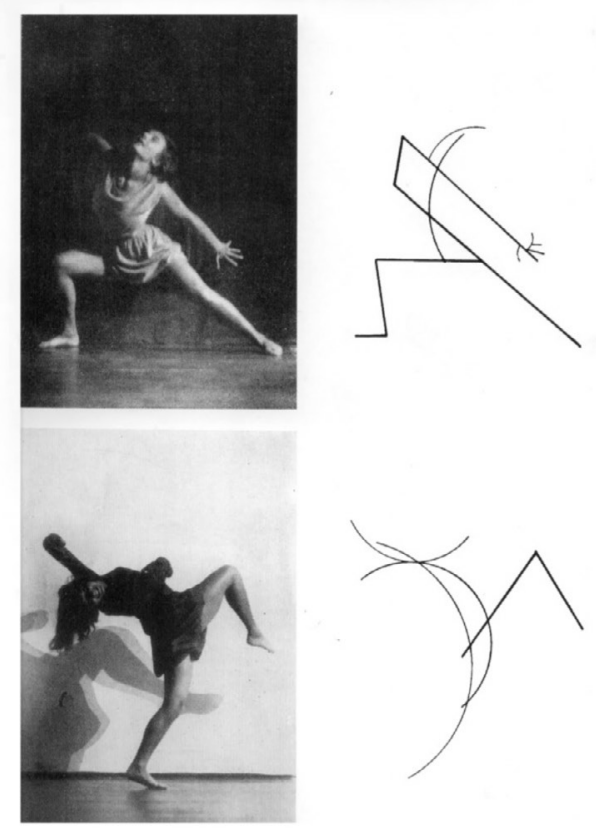
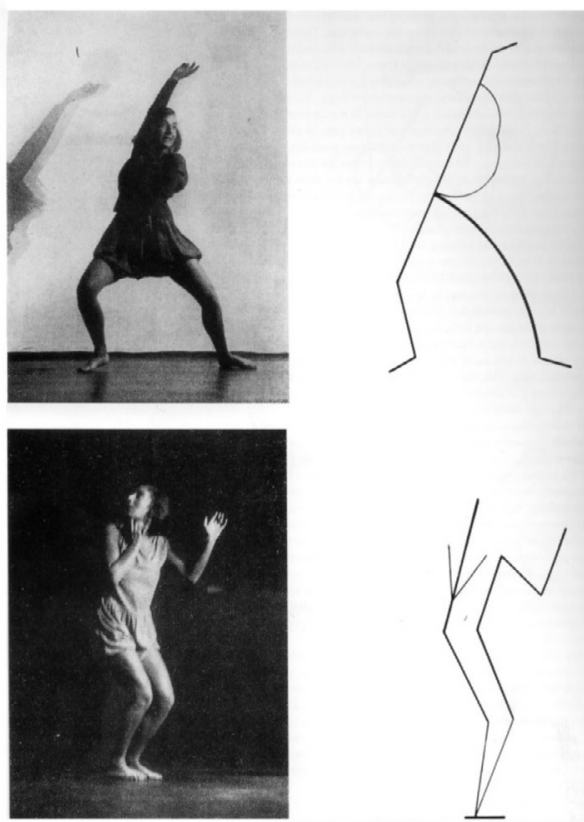

Fig. 3 From Wassily Kandinsky's "Dance Curves: On the Dances of Palucca," 1926. Published in Das Kunstblatt arts journal, also in 1926. Photos by Charlotte Rudolph. beginning with a theoretical study of the most basic components of the individual arts. From this solid foundation, they would develop as artists together in small, analytical increments, comparing and integrating their disciplines at each step. At the end of this cumulative method of study, they would be able to create the monumental work that organically integrated all of the arts: a collaborative piece for the stage.

This program was accepted for implementation at the Russian Academy of Artistic Sciences at that time - but was not carried out when Kandinsky left for Germany.

There, Kandinsky spent the years from 1922 to 1933 at the Bauhaus, perhaps the most famous interdisciplinary arts conservatory in history, with its own experimental theatre. His writings of this period reflect his work as school administrator and master teacher, and his on-going involvement with the 
problems of art teaching. He wrote extensively on the purpose and structuring of an education in the arts, explaining his own system of instruction both explicitly and by inference, and always insisting that his approach would benefit teaching in all the arts, with special reference to the theatre. I recommend the endless administrative planning memos for the Bauhaus as thrilling reading for anyone interested in interdisciplinary education.

Kandinsky's second arts program, then, was designed for arts students who were just beginning their training in a four-year conservatory setting. His goal was to give the students a balance - of practical and theoretical knowledge, of intuition and calculation, of skills for analyzing and integrating. They were to move freely between all the departments, and choose their own yearly projects. As in his Russian program, his courses followed a highly systematic progression. The first term focused on isolating and juxtaposing elements of structure; the second term was devoted to content and complexity; the third term, to content and simplicity. Each year, the students would encounter increasingly complex problems, and the skills to solve them.

Kandinsky was optimistic about the future of the theatre if theatre training could be reformed.

\section{CONCLUSION}

Before I conclude, allow me a personal note: I grew up around the theatre and images of Kandinsky's paintings. Later, as I became an actress, then director and scholar, at each turn, I kept finding what I needed in Kandinsky's writingsand this has never stopped being so. Around 1982, when I was developing as a teacher, I began to focus on Kandinsky's statement that every art discipline should be taught in exactly the same way - and that his system of instruction "should be the method for all other areas of teaching." One passage particularly caught my eye: "...merely apply the corresponding principles laid down for painting, and of its own accord the happy dream of the theatre of the future will rise up..."

These few sentences - as they say - changed my life. In 1985, I founded the Actors' Training Project, to offer Kandinsky's unusual training principles to theatre students. This program ran for 20 years in California, and since 2004, I have introduced this work in major theatre institutions around Asia and the North American continent, as well as in Russia, Sweden, and Mexico. I introduced Kandinsky's theatre work at the Shanghai Theatre Academy in October of 2014, in the second of two lectures, "Towards a New Actor: Stanislavsky, Kandinsky, Schlemmer."

To conclude: In 1976, his wife wrote that Kandinsky's "greatest ambition was to create a large-scale, multi-media ballet"; on the threshold of World 
War II, already in his seventies, Kandinsky was still discussing plans for his "multi-media ballet" with the great Russian choreographer, Leonide Massine. Ultimately, over decades of upheaval, the solitary painter's work proved more viable than the collaborative theatre did. If we give his work serious attention now, early in the $21^{\text {st }}$ century, perhaps we will finally see the theatre Kandinsky saw early in the $20^{\text {th }}$ century. 


\section{MATERIALS IN A SPIRITUAL WORLD:}

\section{A CONTEXTUAL LOOK AT THE YELLOW SOUND}

Clay Gold

\section{ABSTRACT}

The author proposes that The Yellow Sound is a key work in Kandinsky's oeuvre, despite its not being a painting. It is suggested that the "play" is rather a score for an improvised painting, and further, that the piece notates the evolutionary transition between the representational (material) and the abstract (spiritual) in art, with which Kandinsky was so concerned.

Keywords: Kandinsky. Spiritual. Abstraction.

\section{RESUMO}

O autor propõe que Sonoridade amarela seja uma obra fundamental para se compreender Kandinsky, mesmo que não se configure como uma pintura. Há a hipótese que a 'peça' é mais uma partitura para uma pintura improvisada e que, depois, essa obra registra a transição evolutiva entre o representacional (material) e o abstrato (espiritual) em arte, com o que Kandinsky mais se ocupou.

Palavras-chave: Kandinsky. Espiritual. Abstração.

$\odot$

\section{SCENE 1}

"Some indeterminate chords from the orchestra.

Curtain."

The introduction to The Yellow Sound begins like a birth, or a death.

The birth we are witness to is that of Abstraction. The death? Naturalism. The midwife is Wassily Kandinsky's subconscious mind.

The Yellow Sound is a pivotal statement in the career of the artist and he presents it to us in the form, not of a painting or a theoretical essay and, if not exactly a libretto then certainly in the guise of a narrative score; a composition that escorts us through the landscape of a concept-in-progress.

Throughout, objects and figures variously appear and are either discarded or flee from the scene. Landscapes emerge and evolve before they are overwhelmed by colour or completely erased. 
"Dark-blue"

twilight becomes darker still and a "small light" becomes brighter and then "deeper".

One evening around dusk, at the end of the nineteenth century (the very beginning of his career as a serious artist), Kandinsky noticed a painting in his studio. For a moment he was quite unable to make sense of it. It had colour and shape, but nothing to comprehend logically. He quickly realised that the painting had been turned on its side; even so, the impact of seeing the representational work in this unexpected, abstract way, in the half-light, had a profound effect. Retrospectively he wrote about the incident: "I could see clearly that objects harmed my pictures".

"Behind the stage, a CHORUS is heard..."

Deep and high voices using impressionist language. Impressions of language.

The Yellow Sound is not tethered to the logic of a plot or to any distracting narrative arc. There are no leading characters, except for maybe five yellow giants who grow and shrink in confidence, related to the purpose of their presence. Unlike contemporaneous work by Kokoschka and the German Expressionist playwrights, the piece is not political. It does not even deal with universal issues. It does however address, and simultaneously document, a great transition in the history of visual art. And by seeking to express the inherent dialogue of that extended moment within a temporal framework, with music and with choreographed movement and lighting, The Yellow Sound invokes a system of symbolic thought which is both inside and outside of time and the physical world. Like Jack Kerouac's Visions of Cody, a long novel which contains all the impressions and memories contained in one single, vital instant; similar in many ways to Joyce's Ulysses, which deliberately contains more information than can be packed into the single day on which it happens to be set, The Yellow Sound supplies us with an artist's topography of process; a dilemma or tension coupled with emotional or spiritual responses to the creation of five paintings that emerge on stage in three dimensions, before our senses.

"The stage must be as deep as possible."

"...the background becomes dark blue (in time with the music) and assumes broad black edges (like a picture)". 
For Kandinsky, the purpose of art is to communicate a resonance of the soul, creating "a virtually identical vibration in the receiving soul". He is however, acutely aware of the potential for other, inevitable forces which interfere with that process. These differences within the souls of the "receiving subjects", the audience of observers, paradoxically result in the correct understanding of the artist's intention, at a level which is appropriate for each individual.

By allusion... by not speaking directly... by not being didactic or cerebral... meaning is able to bubble to the surface of the soul, to simmer... this is the dot, the crash, the beat... the moment of subconscious or soulful resonance which is not necessarily translatable into (or communicable with) language, but is, according to Kandinsky, transferable with art.

Sympathy and the communication of ideas and emotion happen spiritually and not through any process of logical conclusion or consideration; they are rather instantaneous, immediate. Felt.

Drama, opera and ballet, all being what Kandinsky calls substantive forms, originate from external, considered human experience, and are therefore limited or "impoverished".

“...no movement, no sound. Then darkness.”

"Five bright yellow GIANTS."

“...strange, yellow faces which are indistinct.”

Impressions of humanity, of the figure, for the newborn.

The giants are perhaps symbolic of the great urge, present in Kandinsky's thinking from very early on, to communicate his theory of "the spiritual in art". They are the elephants in the room of Kandinsky's subconscious. In The Yellow Sound he is exploring a new way of bringing them into the material world. Into consciousness.

Yellow is defined as shrill, stimulating and earthly in Kandinsky's theory of colour, 1911. Earthly warmth and shrill seem at odds with each other. And why not? Why should any colour, tone, or chord be singular or specific in its meaning to a human being? Meanings, if any, are relative to one another and to all that occurs around them. Similarly, the resonance within a work of art is only present in relation to the previously acquired knowledge and information which is present in the mind of the observer. 
"The music becomes more definite."

Clarity. Momentarily.

And a repetition from earlier, “...the same wooden chorus becomes audible."

\section{SCENE 2}

"The blue mist recedes gradually before the light..."

Consider this, for instance, as an example of describing the production of an improvised painting:

"At this point the background suddenly turns a dirty brown. The hill becomes dirty green. And right in the middle of the hill forms an indefinite black patch, which appears now distinct, now blurred."

Kandinsky is painting, eyes closed.

"On the left side of the hill a big yellow flower suddenly becomes visible."

"Later, in complete silence, the flower begins to sway very slowly..."

From On the Spiritual in Art: "A totally dead silence... a silence with no possibilities, has the inner harmony of black."

$A$ thin " $B$ " tone accompanies the sway whilst a deep " $A$ " represents a leaf. Music is the spiritual resonance Kandinsky hopes to transmit to the observer through his imagery. These notes are the frequencies which he is experiencing and reproducing for the audience. The music is almost unnecessary as it represents something occurring within the artist and should therefore reoccur within any sympathetic soul, like the keyboard and strings he describes in On the Spiritual in Art... an inner music, sensation.

The Yellow Sound is an opportunity for Kandinsky to present, in its purest form, his theory of "the spiritual in art", the resonance represented by music and the eventual use of synaesthetic language. With the libretto, Kandinsky is free of theoretical constraint and is able to be an artist again, painting with words for the soul without the interference of the psyche.

"Many PEOPLE come on from the left in long, garish, shapeless garments..." 
They sing:

“Close your eyes! Close your eyes!”

The voices are "hoarse", "possessed" and "nasal", individually defective or distorted. The figurative is now breaking apart in Kandinsky's output; the Abstract, symbolism, is growing stronger, with greater resonance.

"Gradually, the orchestra strikes up and drowns the voices."

Spirituality is apparently overcoming representation.

"The PEOPLE walk slowly... and separate more from one another."

Materialism is fragmenting.

"It turns suddenly dark."

SCENE 3

“...the GIANTS... whisper in pairs; sometimes all their heads come together.

Their bodies remain motionless."

"Everything remains motionless... Suddenly all colours vanish."

"...the music grows deeper."

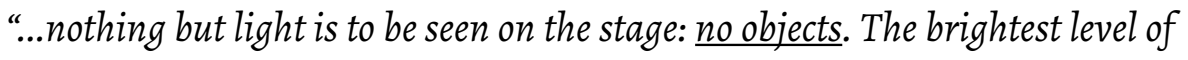

light is reached."

We arrive at complete abstraction.

"...behind the stage a shrill tenor voice, filled with fear..."

This voice is the sound of bright yellow in Kandinsky's colour theory.

“...shouting entirely indistinguishable words very quickly..."

In the artistic lexicon of Kandinsky, the words sound and colour are interchangeable. He uses the word "sound" to describe the spiritual quality of any art. This is perhaps a way of creating the type of meaning which speaks 
to the soul as opposed to the mind. Or it could be that his synaesthetic disposition sees no distinction between the two words.

It is however possible for us to identify this "shrill tenor voice" as being the very "yellow sound" of the title. It occurs twice more at important junctures in the piece, and is specifically heard emanating from a human being; it is therefore not unreasonable to think of it as the last cry of naturalism in art, especially when considered at this particular crossroads in the work of the artist. Although it was to be more than ten years before Kandinsky eradicated broadly recognisable figures from his painting, The Yellow Sound may be read as a tortuous psychological wrestle with that very issue. The constant tension between the outer and the inner world is consistent with Kandinsky's character. It is well documented that he came late to art, having first studied law and economics, a judicious attempt, perhaps, to keep one foot in the material world before indulging in the spiritual endeavours of painting and theorising art and colour.

"Pause. For a moment it becomes dark."

\section{SCENE 4}

Out of nowhere (darkness), a figurative painting is presented to us:

A simple religious building, with a turret and a "cracked bell."

A small child, gazing out at the audience is ringing the bell by:

"pulling slowly and rhythmically at the lower end of the rope..."

A fat, white man, dressed in black, demands

"Silence!"

of the child, who obeys.

Is the child interfering in some way with the proceedings? Does the man in black represent some authority calling for an end to this adventure in abstraction? The stern man may be read as some kind of outside interference; Kandinsky's conscience pricking him maybe, or a symbol of the suppression of the individual's spirituality by the authority of organised religion: a metaphor for the resistance of culture toward the expression of nature in art. 
Maybe the figure is the lawyer that Kandinsky rejected in order to become an artist. I think this is highly likely.

The broken bell represents the imperfect, though vital, transmission of spiritual resonance.

"The CHILD drops the rope."

This is the only scene of true or traditional drama in the piece and I believe it is strongly resonant for Kandinsky.

\section{SCENE 5}

"The stage is gradually saturated with a cold red light, which slowly grows stronger and equally slowly turns yellow."

Kandinsky, in the book Uber das Geistige in der Kunst (1911), says this:

"The element of red, which plays a great part in orange... is like a human being aware of his own power and emanating happiness and health. The appeal, exercised by this colour is like a medium-sized church bell reminding one of a strong alto voice or the singing of alto violins."

With this in mind, we gain some insight into the previous scene. The colour emerges from the bell and represents the actions of the child resonating still from the outer world (of the bell) to the inner world (of colour). Sound bleeds into light.

Backstage, the fearful (yellow) cry is heard again very briefly. A white, shadowless light is growing and, simultaneously, the giants become "feeble". They are reduced to a motionlessness, staring out at the audience, before they suddenly "spasm".

"The music gradually becomes shriller", which is the same as saying the music becomes yellow. The stage becomes flooded with people, some dressed in black and white or grey; others in bright colours. They behave differently too, in groups, before they become displaced, alone or in smaller groups, looking in different directions. One of the white figures performs a "kind of dance" with rapid movements, drawing the attention of the others until they are all looking at the white figure. The dance ends with a ritualistic movement and there is a spiritual tension between colour, choreography and music at this point. 
"In the orchestra, individual colours begin to stand out."

The people, "overcome by exhaustion", begin to stand and the groups disperse:

"Many PEOPLE run in haste from the stage, looking behind them. In the process, all the BLACK, GREY and WHITE PEOPLE disappear..."

"In the orchestra-confusion."

The giants tremble as the yellow shriek from backstage is heard once more. A rapid, chaotic, ensemble dance ensues and, at the moment of "greatest confusion" in the music and in the lights,

"it suddenly becomes dark and silent."

The yellow giants remain as the last visible objects before they then too become erased.

Wassily Kandinsky's mindset at the creation of The Yellow Sound is likely that which is present at the creation of any other "composition" or "improvisation" upon which he worked, any of which could be plays or paintings or symphonies. But here, instead of a brush, he has a pen or a typewriter. And instead of an abstraction, we have here the entire thought process, in plain language, plainer than he has used before or since. And instead of a painting, we have the score for a painting. A score which allows for ideas to be overwritten with new ideas.

Kandinsky's "spirituality" is synonymous with the "unconscious mind", an expression still new in the parlance of the time. Its use was popularized by the writing of Sigmund Freud after 1900 and spread even further once his work was translated into other languages, from about 1912. Prior to Freud, the psyche was a mystery, explored by occultists, theosophists and thinkers of the era in broadly imaginative ways which owed more to poetry and religious unravelling than it did to scientific analysis. Until The Yellow Sound, Kandinsky perhaps lacked the language of clarification for his philosophy. The framework of a theatrical play eventually freed him to speak using the metaphors presenting themselves to his synaesthete thought processes. The deliberate, conscious construction of similar work, the Gesamkunstwerk of Richard Wagner for 
example, opposes the instinctive or intuitive methods of Kandinsky. Wagner's use of tropes and specific cultural symbols - the "well-known label" on a bottle, were the Wagner branding. He used narrative text to express his own ideas, a method antithetical to Kandinsky's own beliefs. "Wagner diminished the inner sense" with his ignorance of colour, as Kandinsky put it; not to mention the practice of subordinating one art-form to another, and the "obstinate recurrence" of musical phrases in his method of characterization. Wagner was a composer typical of the "external", the superficial style to which Kandinsky was opposed.

This is poignant and pivotal because The Yellow Sound came as Kandinsky was crossing the threshold into pure abstraction; as we know from his early artistic career, he never made a move in the field impulsively. That's not to say that he never intended the piece to be a theatrical performance. I'm sure he did. But in the spiritual unconscious of his artistic drive he somehow unlocked the symbols which represented the greatest leap of his life. And he wrote them into The Yellow Sound.

J.L Styan describes August Strindberg's contemporaneous Ghost Sonata as not being "a play... perceived with the logical mind, [but] one to be savoured with the senses". This strategy might also be applied to The Yellow Sound. Kandinsky's work is not, however, a dream play, but rather one exploring the tensions between the conscious and the subconscious, the material and the spiritual worlds within the mind of an artist who has reached a vital fork in the metaphorical path of his development. He truly wished to transmit the interior, soulful experience of a spiritual artist to the observer, through the ears as well as the eyes. His apparent desire was the ability to tap into a resonant frequency, to make a true connection with other people. I think he admired the ability of religion to connect with the devout in this way. Religion, using artistic tropes: symbol, metaphor, architecture and acoustic design, is able to envelop, not to mention humble and overwhelm the dedicated attendee. In many ways religion is the supreme art form, as followers carry their experience into the external world of objects. The chapels of Rothko in Texas and Matisse in Vence testify to this, representing endeavours to enter into this kind of communion.

It is my conjecture that Kandinsky may just as well have expressed his theory as The Unconscious in Art, rather than the Spiritual, given the broad exploration and discovery taking place in the realms of psychology and psychoanalysis at the same time. Regardless, his most important dramatic work, The Yellow Sound, can be read as the score for a synaesthete theatre of the mind.

There is something like twenty-five years between The Yellow Sound and the extraordinary, object-free work of the Bauhaus-era paintings; work which is precise, geometric and finally stripped of all representation. Within that 
period there exists a transition, recorded in The Yellow Sound libretto, which triggers in my mind the image of the bone in Stanley Kubrick's 2001: A Space Odyssey, tossed into the air by a prehistoric ape, the bone dissolves into a revolving, futuristic space station in a matter of seconds. Within the work of Wassily Kandinsky there exists the great evolutionary stretch between representation and abstraction in the arts, which had further resonance in all other fields. He did not act alone in the process, but the birth trauma, the journey and the questions, the tension and the guilt are all expressed in his oeuvre. It needed, perhaps, a synaesthete to sense it and create a theatrical, rather than theoretical, record of the transition.

Clay Gold 2018 


\title{
4. MEMORIES OF A VERY EARLY WITNESS
}

Jelena Hahl-Fontaine

\begin{abstract}
The 82-year old art historian and slavist Jelena Hahl-Fontaine (formerly HahlKoch) has spent most of her professional life on the many-sided innovative artist Kandinsky and has collaborated on and witnessed some of the performances of his stage plays.
\end{abstract}

Keywords: Kandinsky. Stage Plays Performances.

\section{RESUMO}

A historiadora e eslavista Jelena Hahl-Fontaine, de 82 anos (antes Hahl-Koch), envolveuse na maior parte de sua vida profissional com o multiartista Kandinsky, tendo colaborado sobre o tema e participado como audiência de muitas das encenações das composições para o palco do pintor.

Palavras-chave: Kandinksy. Composições para o Palcos. Encenações.

When I was still a student, in the mid-1960s I began to archive Kandinsky's bequest, which had come through his partner, Gabriele Münter, to the Städtische Galerie (City Gallery) im Lenbachhaus in Munich. His numerous manuscripts, with various "scenic compositions" from 1908 on - in Russian (which I translated at the time) and in German — fascinated me as examples of a synthesis of the arts. The sense of this "synthesis" was similar to what Alexander Skrjabin [Scriabin] had intended, and was in any case more complete than Richard Wagner's: from the early Giants, The Green Sound, Black and White, up to the final The Yellow Sound, the only play Kandinsky found complete enough to publish in his Blue Rider Almanac in 1912.

My studies in various archives, the Getty and Norton Simon museums, Yale Music Library, the Tretjakov gallery in Moscow, a 12-year long cooperation with Nina Kandinsky, etc., added to complete the picture. When the Lenbachhaus exchanged copies with the Centre Pompidou, where Nina Kandinsky had later given other manuscripts, the process of the artist's ideas became clearer and more logical. I was able to observe a path towards more and more abstraction in the stage plays, exactly parallel to the development of his art: to add the elements of time 
and movement to his images, change the lighting, experiment with neighboring forms of art... Paintings of the same period in Chicago and Amsterdam proved to have a direct connection (see the illustrations in my Kandinsky-Forum III and my monograph Kandinsky of 1993). Less and less comprehensible "action" could be observed in the stage plays, human figures were soon used only as carriers of color, their movements were without "logic," and so on.

Two long stays in New York and Garches near Paris with Olga de Hartmann (the singer, widow of the composer Foma Gartman/Thomas de Hartmann) were quite a revelation. Olga herself had been an active partner in Kandinsky's project in 1908-1912; we find mainly her handwriting in the manuscripts along with the more naive, almost childish handwriting of her husband. I was mainly interested in the old recording of Hartmann's music for The Yellow Sound, and Olga played the very poor quality wire recording on a "spiral system," which I copied somehow.

Author's Note: For this, I am hoping now to find some technically competent young helpers to get something useful out of this recording....A cooperation is planned for 2018/19 to publish the letters between Kandinsky and the Hartmanns, in Russia first, since the language is Russian.

Just a few personal words, since otherwise this might never be known: Olga was then far over 80 , her face full of wrinkles, but it was the most beautiful face I have ever seen: a pure soul! And how extremely sensitive she was: once she simply started crying, sobbing, when she told me that Nina Kandinsky, when already rich in Paris, did not want to take her mother to live with her. Olga herself had taken her old father, a widower, to live with them. - Thomas de Hartmann's book on Gurdjieff, to which Olga also contributed, shows their spiritual quest. She also told me that she had never gotten her menstrual period, so she could not have children; Thomas had answered her father when asking to marry her, "Music is our child." Although I strictly refused to join her when she wanted to introduce me to a Gurdjieff circle, she herself must have felt some basic interest, at least in general spiritual (not esoteric!) matters; indeed, her dedication in their book proved prophetic...

With Munich's museum director, Hans Konrad Röthel, I had almost finished a theater volume, which was to be published in 1981/2 at Benteli in Switzerland. But only the first volume with Kandinsky's autobiographical writings was published in 1980, and the rest was hindered by Paris "colleagues"... But all my materials became part of the Paris project, where many years later a large and thorough edition (with the added help of Natasha Avtonomova) was finally 
published. In 1980, I edited a complete volume of Kandinsky's correspondence with Arnold Schoenberg, and since their letters touched on the subject of The Yellow Sound and Schoenberg's Lucky Hand, I included those plays in the book. At the end of 2017, a smaller Russian edition came out at "Grundrisse" in Moscow.

I then published, finally in 2010, Die Bühnenexperimente in the series Kandinsky-Forum III. I have also been invited over the years to give lectures on this interesting subject: twice at the Tretjakov Gallery, the Conservatory Leningrad, twice at the Schoenberg Center in Los Angeles, in Montpellier, Munich, Sidney, Bogotà, Brussels, Dijon, Basel, Chicago, and more.

\section{PERFORMANCES}

Kandinsky's The Yellow Sound project with his close friend, Foma Gartman [Thomas de Hatmann], left notes and an early recording on a "spiral system." - In 1914, Hugo Ball, later the Dadaist, wanted to stage it in Munich, but it did not happen because of the outbreak of World War I.

The next staging of The Yellow Sound took place in Southern France and then in the fine Theâtre de Chatelet in Paris in 1971, on the initiative of Nina Kandinsky and her new close friend, Claude Pompidou, the wife of the president. With the exception of myself, only rich and famous representatives of the Paris political and cultural society were invited; they had to pay a lot, since it was a "benefit" performance. At the piano, scenographer Polieri (no, not the more famous Pollini) was in charge, he had already staged The Yellow Sound in Beaume, in Southern France, just before Paris. The evening started with the minute-long projection of the face of Kandinsky, then the face of Polieri — and then many more times, Kandinsky and Polieri... Kandinsky and Polieri. Which shows the enormous ego of Polieri. He played whatever had nothing to do with Hartmann's music... Also, the stage play was rather far from the ideas of Kandinsky. Film projection was used for the flight of the red birds. Result: not good, but "luxurious," especially when at the end every woman was given a beautiful yellow rose...

In 1982, I was invited by the Guggenheim Museum to help with a more thorough staging of The Yellow Sound. Hartmann's music was used, but since it contained only fragments (and the idea was to have a full-evening event!), the composer and professor at Harvard, Gunter Schuller, "completed" it: too bombastic, I found. I was also against the stage director, Jan [Ian] Strasfogel, whose ego seemed too dominant to follow Kandinsky's intentions. When he finally decided that the Giants had to have huge hats with geometrical "Bauhaus"-like forms, I quit the cooperation and only gave a lecture at the Guggenheim Museum. 
Then I heard that the Russian composer Alfred Schnittke had written something, inspired by The Yellow Sound. When he came to Brussels to direct his own compositions, I confronted him: I don't remember my words, but he understood that I found his idea inadequate, since he did not even know Hartmann's music. But he answered very nicely and modestly: "No, Kandinsky is a giant!" So he did not mean to be equally important (and Schnittke's later music I began to love very much, so I was completely consoled).

When later I was asked to contribute my materials to a project to stage Pictures at an Exhibition in Berlin in the early 1980s, I gladly sent copies to Mr. Ruprecht, since I had a complete copy from Felix Klee, Kandinsky's young helper in Dessau (I just recently did the same for the Moscow project, "Planeta Kandinsky"). And that Berlin production - which is of course easier to do than The Yellow Sound, since Kandinsky has written many more details for it than for the earlier play - I found quite perfect and impressive. In Moscow, in November of 2017 the former assistant of Rupprecht, Mr. Birr, explained how meticulously they had proceeded in Berlin; it has been a huge amount of work and a really extremely exact reproduction of Kandinsky's performance in Dessau in 1929. And we are all happy to hear that Mr. Birr can still continue to show this reconstructed performance even now.

\section{IMPACT ON GERMAN EXPRESSIONIST DRAMA}

Since Kandinsky's On the Spiritual in Art had become an appreciated and admired manifesto of modernism, his next publication, The Blue Rider Almanac, was also widely read by all culturally interested people. So The Yellow Sound, which he included along with an explicatory text to it, became well known. And since the artist, in this neighboring non-professional domain, felt free to experiment - more than in his "own" art and more than any professional drama-author dared to do at that time - this shocking, almost abstract play had an enormous influence on the German expressionist development of drama and opera. To name only one: Lothar Schreyer, of Herwarth Walden's famous circle "Sturm" in Berlin, was quite influenced and also wrote his interpretation of Kandinsky's play... Schreyer's work, which is hardly performed anymore, I had studied in the archives of Marbach/Germany; and when at last a performance was to take place at the Wuppertal Museum, I sent my materials. 


\title{
5. VERSIONS OF THE TEXT OF THE YELLOW SOUND
}

llona I. Krymskaya

\begin{abstract}
Kandinsky worked on several stage compositions between 1909 and 1912. He left most of them uncompleted, instead focusing on refining The Yellow Sound. The author studied seven versions of the text, discovering important clues about his process and intentions.
\end{abstract}

Keywords: Stage composition. The Yellow Sound.

\section{RESUMO}

Kandinsky elaborou diversas composições cênicas entre 1909 e 1912. Ele não completou a maioria dele, focando-se mais nas revisões de Sonoridade Amarela. Aqui são estudadas sete versões desse texto, revelando-se revelantes indicações acerca do processo e dos objetivos da obra.

Palavras-chave: Composição Cênica. Sonoridade Amarela.

Wassily Kandinsky's stage composition The Yellow Sound is a unique phenomenon of the synthesis of the arts of the early twentieth century, a quintessence of the artist's innovative theatrical ideas and a practical realization of his conception of stage synthesis. In this experimental production, Kandinsky realized his ideas on the transformation of the traditional stage environment, the elimination of external events, the abolishment of the hierarchy of elements of stage synthesis, and the dematerialization of stage action.

The text of The Yellow Sound is a description of the movements of different elements of the composition (music, words, light, color, choreography) without any narrative or attempts to explain the work's meaning. There is no traditional plot and very little dramaturgic text, part of which is zaum speech. The sound of the human voice is used sonorically, the characters are depersonalized, and the actors are perceived as vehicles of color and as forms that have come to life. The author's cinematographic thinking is manifested in his precise timing indications, elaborate recommendations for the music, and numerous brief fadeouts that create the impression of the limits of a cinematic shot or cut. The score of colored light is well developed, animation elements are used. 
Kandinsky worked on The Yellow Sound between 1909 and 1912. During that time he changed its name twice (The Giants, The Yellow Flower), as well as its significance in a series of similar ones: at first, the play was included in a cycle, with three others; later it became the only fully published dramaturgic piece by the artist. In its final version, the composition was based on the original material, but to some extent also on material borrowed from other compositions in the tetralogy.

Kandinsky resisted the temptation to create the cycle of plays, so that only The Yellow Sound remained, in a version that incorporated ideas from the earlier, unfinished plays Daphnis and Chloe and The Garden of Paradise. Having gotten deeply acquainted with the texts of all theatrical works by Kandinsky, analysed his theoretical works, and studied the artist's biography, I can suppose that starting from September of 1911, Kandinsky was already not planning to refine stage compositions II, III and IV (The Voices or The Green Sound, Black and White, and The Black Figure), or the Epilogue for the tetralogy, having made the decision to publish only The Yellow Sound, the quintessence of all his innovative theatrical ideas. Some episodes and scenes of these three compositions and the Epilogue were included in the stage composition of 1914, The Violet Curtain. Thus Kandinsky did not consider stage compositions II, III and IV to be finished works. Later the artist never doubted the choice he had made. He never again approached stage compositions II-IV, but instead refined The Yellow Sound and tried to have it produced again and again, but unfortunately failed.

Seven different versions of The Yellow Sound text remain - two in Russian, the others in German. The last one, the seventh version, exists in three documents; each contains original remarks written in the hand of either Kandinsky or Thomas de Hartmann (who was writing but did not finish the music for the composition), remarks which shed light on the work process of the author and the composer.

Still today, researchers have not paid enough attention to the various versions of the play. I was able to put all texts and related documents of The Yellow Sound into chronological order, which made it possible for me to follow the evolution of Kandinsky's ideas. Stylistic alterations in the texts show that from the very beginning The Yellow Sound was created as a theatrical avantgarde work. While elements inherited from the Symbolist theatre dominated in the first variant, signs of growing Expressionism, as well as features of nascent Surrealism, Dadaism and the Theatre of the Absurd showed up in later versions (cf. my dissertation). 


\section{SELECTED REFERENCES}

Kandinsky 1998: Wassily Kandinsky, Du théâtre / Über das Theater / Отеатре, ed. Jessica Boissel (Paris, Société Kandinsky).

Kandinsky \& Marc 1914: Kandinsky, Wassily, \& Marc, Franz (Hrsg.), Der Blaue Reiter (München, R. Piper \& CO. Verlag, It edition 1912).

Krymskaya 2018: Krymskaya, Ilona I., Sceničeskaja kompozicija "Želtyj zvuk" Vasilija Kandinskogo: genesis, èvolucija zamysla, xudožestvennaja struktura $i$ interpretacija (Stage Composition The Yellow Sound by Wassily Kandinsky: Genesis, Conception Evolution, Artistic Structure and Interpretations), Ph.D. Dissertation, Saint-Petersburg, 2018. 


\title{
6. REVIEW: “AVANT-GARDE THEATRE SHOWS \\ ITS AGE WITH BAUHAUS VIOLET" \\ Marianne Ackerman
}

\begin{abstract}
It is difficult to find productions of Kandinsky's stage composition Violet, but theatre critic Marianne Ackerman saw one in 1985 and wrote a review of it which has since been cited. With a description of the staging and Ms. Ackerman's recent comment.
\end{abstract}

Keywords: Kandinsky. Stage. Violet.

\section{RESUMO}

É dificil encontrar montagens da composição cênica Violeta, de Kandinsky. Mas a crítica teatral Marianne Ackerman pode observar um em 1985, tendo escrito sua apreciação, a qual sempre é citada. O texto contém uma descrição da encenação de Violeta, acrescido de recente nota da autora.

Palavras-chave: Kandinsky. Teatro. Violeta.

The play of Kandinsky's that is most often produced is The Yellow Sound, which he published along with a theoretical essay containing some explanation of his intentions. There has also been some interest in the visual staging Kandinsky created for Mussourgsky's Pictures at an Exhibition, which offers Mussourgsky's music as a foundation or starting point.

But Kandinsky's Violet, even though it is one of his most realized plays, is hardly produced. So I was delighted to come across a reference to a production of it in Establishing Our Boundaries: English-Canadian Theatre Criticism, by Anton Wagner (p. 375):

The nonverbal explorations of francophone theatre gradually became one of [critic Marianne] Ackerman's measures of a theatrical experience; an impressive recreation of Kandinsky's Violet in December of 1985 led her to reflect upon how limited were the resources that (anglophone?) theatre generally allowed itself to draw upon [...] However, her admiration did not blind 
her to excess, and even in the case of directors whose work she admired she refused to allow music, colour, and movement to replace the virtues of a strong script...

I was unable to locate the director of the production, Claude Sabourin. But for this Special Issue, Marianne Ackerman was kind enough to locate her review of the production in her files. The text of that review follows.

Lissa Tyler Renaud

○

Montreal Gazette, Friday, Dec. 13, 1985

\section{AVANT-GARDE THEATRE SHOWS ITS AGE WITH BAUHAUS VIOLET}

By Marianne Ackerman

Gazette Theatre Critic

The problem with modernity in the theatre is that it is so old.

Rarely has this sobering fact been announced more clearly than it is by Violet, staged this weekend as part of the Goethe Institute's Bauhaus festival.

An innocent stumbling into the event might attribute this sprawling, disjointed performance to American painter/director Robert Wilson, so close is the form and content in the atonal, nonlinear, painterly theatre of today's avant-garde.

\section{'SCENIC COMPOSITION'}

In fact, down to the textually-specific three, five and 14-second pauses separating every howl and grimace, Violet is a "scenic composition" created in 1911 by Wassily Kandinsky.

Otherwise known as the father of abstract painting, Kandinsky taught at the Bauhaus school and wrote theoretically about painting, music and theatre.

According to the director's notes, Rideau Violet (its original title) never received a second production. Whether that neglect is shameful or deserved is a contentious question, but as directed by Claude Sabourin, Violet is proof that the avant-garde has no repertory. Each generation seems content to reinvent the destruction of the wheel.

With a cast of students from l'Université du Québec à Montréal, the 80-minute performance is a taut series of tableaux. Technically, the bridges between scenes are rough, but visually Violet succeeds in making the painter's 
knowledge of color and form an indispensable part of the action, which is fortunate, because there is no action in the theatrical sense, no plot or characters, only human gestures expressing the author's theories.

Kandinsky considered the theatre a total art form, at least potentially. By dropping all conventions, he hoped theatre could create a synthesis of all other arts and accomplish what he considered the aim of all art: the creation of material form to communicate "spiritual vibrations" between artist and audience.

On a bare white stage, stark circles of primary colors are beamed from several directions. (Colors are codes: yellow is a triangle, red a square, blue a circle and violet, the color of intellect.)

Lines and movement are epigrammatic. A boy in a wagon moans, "I can't get up. I can't be born." A couple embrace, then fall to the ground. There is laughter offstage and applause from the cast. Some chant "poor fish, poor men."

Two men in evening dress set a table with grapes, then swing it until they fall. There are slides of Kandinsky's work, and a marvellous finale of red neon lines that seem to dance (attached to an unseen figure in black), and a wide repertoire of music styles, each snippet ending abruptly, with no clear connections.

Violet is never boring. But it is not a spiritual experience, except perhaps for those who've pondered the sacred texts and come determined to worship at this lively tribute to the master.

\section{TRUE MYSTERY}

The true mystery of Kandinsky's theatre isn't why his "scenic compositions" are so rarely performed, but why his thoughts have been so thoroughly ignored.

Why is the theatre today so routinely cluttered with heavily furnished TV dramas, when the stage has so long ago been rediscovered as a forum for mind, spirit, color and movement, in short, for a journey inward?

I asked Ms. Ackerman if she had any further remarks about the production, looking back on it over thirty years later. Her interesting reply:

April/December, 2018

At this point, I should add that Robert Lepage and his generation of theatre creatives have pretty well answered my main question - and definitely taken Kandinsky's ideas in new directions. Not sure I can say that anglophone Montreal theatre has followed, but the main stages in Toronto, francophone 
Montreal and Quebec are now attuned to the visual power of theatre. Stark realism is one genre among others. 


\title{
7. KANDINSKY EXPERIENCE:
}

\section{FROM PICTURES AT AN EXHIBITION TO PLANET RANDINSKY}

Giovanni Vinciguerra

\begin{abstract}
My experience working on the performance Planet Kandinsky - a reinterpretation of Pictures at an Exhibition, which Kandinsky staged in 1928. Immersion into and study of the inner world of the painter and his artistic aspirations by creating design-light, music-sound, dance-movement on stage.
\end{abstract}

Keywords: Abstract. Light\&space. Synthetic.

\section{RESUMO}

Relato aqui minha experiência de criação da performance Planeta Kandinsky, uma reinterpretação de Quadros de uma Exibição, que Kandinsky encenou em 1928. Por meio de Iluminação, produção sonora e coreografias realizou-se uma imersão e estudo no mundo interior do pintor e suas utopias artísticas.

Palavras-chave: Abstração. Luz\&espaço. Síntese das Artes.

\section{BRIEF INTRODUCTION}

The performance Planet Kandinsky was a contemporary reinterpretation of, or commentary on, the production of Pictures at an Exhibition, Modest Mussorgsky's music, which was staged by Wassily Kandinsky at the Friedrichtheater, Dessau, in 1928. An exact reconstruction of Kandinsky's production was carried out in 1983 at the initiative of the Academy of Arts in Berlin by a group of students under the direction of Martin Rupprecht and Horst Birr. Planet Kandinsky was created by an independent group of students of different years and departments of the Moscow Art Theatre (MKhAT) School, in collaboration with several artists. This new version included various reconstructed elements of the original designs made by Kandinsky. Nevertheless, they were used only as motifs and images that were reinterpreted within a new visual space, where they interacted with other motifs stemming from Kandinsky's work, as well as with newly created images. Similarly, Mussorgsky's original music in a new arrangement was combined with brand new musical lines specially created for the production. 
I will try to describe my production, also thinking from the spectator's point of view. I recommend watching the video of the 1983 reconstruction of Pictures at an Exhibition even before reading my essay. The link to Planet Kandinsky also follows:

\section{Pictures at an Exhibition, 1983}

\section{Planet Kandinsky, 2017}

\section{ABOUT THE PRODUCTION}

When I first discovered Kandinsky's Pictures at an Exhibition, I was astonished by the images of living pictures where, in the almost total absence of humans, geometrical shapes move and interact with each other, creating one visual composition after another. The stage - the place where this action occurs becomes an abstract space. Before, as a beginning young scenography student, I had rarely felt attracted to abstract paintings. This stage composition opened my mind to the very spirit of this art. No books, exhibitions, talks, etc. help so simply to understand the sense of abstract painting.

So I dedicated myself with great pleasure to research on Kandinsky's work and more generally on the Bauhaus and started the project with the idea of reconstructing the original performance. In fact, working with Pictures at an Exhibition had for me first and foremost great didactic signifigance, as perhaps every reconstruction does. That was a major feature of the 1983 reconstruction created therefore by students of the Academy of Arts in Berlin. So it was the most important engine for my work, too. Somehow this incredibly dense and rich period of art history provides the key to the comprehension of many contemporary art forms or makes them at least far clearer. The exhibition Musicircus. Masterpieces from the Centre Pompidou Collection, held from April 2016 to July 2017 in the Centre Pompidou-Metz, was very important for me. In this exhibition, the history of contemporary art was reinterpreted through the prism of music, starting from the beginning of the $20^{\text {th }}$ century. After Kandinsky, art did not stop moving forward towards greater abstraction. Trying to draw the line between the origins and contemporary forms was inspiring for me. At that point I became more interested in exploring this experimental piece with the tools of a new artistic language. We renounced making a complete reconstruction (which would also have been too expensive) and decided upon an experimental interpretation on the basis of some selected original pictures.

The next step was to conceive the new aesthetics and principles of the upcoming production. But before that let me describe briefly the creation of 
Pictures at an Exhibition composed by Mussorgsky in 1874. This work was inspired by his walk through the Memorial Exhibition held in the Imperial Academy of Arts in Saint Petersburg, dedicated to his good friend, Viktor Hartmann. This was shortly after the latter's death, and the composer was deeply moved and impressed. The randomly exhibited drawings were created by the architect Hartmann while traveling through the cities and countryside of Europe and the Russian Empire: there were architectural drafts and copies, costume and stage designs, depictions of scenes of everyday peasant life, landscapes, and urban sketches. Every musical piece of Mussorgsky's composition narrates these works and expresses his emotions inspired by the death of his friend. The Promenade, on the other hand, corresponds to visitors moving from one picture to another in the gallery space. The greater part of these priceless drawings has been lost. Some correlations of music pieces and pictures are not certain or even false, as, for example, the drawing of an old man that was supposed to have been the prototype for Mussorgsky's piece Rich and Poor Jew or Samuel Goldenberg and Schmuyle turned out actually to be a drawing of an Italian peasant. I garnered the information in this paragraph from my wonderful conversation in November 2016 with Natalia Mutya, lecturer at the Stieglitz State Academy of Art and Design in St. Petersburg, who dedicated her dissertation to the work of Hartmann.

Kandinsky, a great admirer of Mussorgsky's music, evolved his abstract watercolor sketches in response to Mussorgsky's musical pieces. He wrote in 1930, "[I] used forms that swam before my eyes on listening to the music." I followed the interesting chain of inspiration "picture-music-picture-stage composition" and, with the help of the 1983 film and my model reconstructing the 1928 performance, focused on the emotions and associations that were born in me when watching Kandinsky's pictures in motion. The start of my collaboration with the performer and film director Pyotr Laden gave an essential impetus for conceiving the new aesthetics for the production.

We concentrated on the impact that such a high level of abstraction would have made on the spectator and set ourselves the goal of recreating it. Throughout our work, geometrical shapes started to appear everywhere in our everyday lives. Inspired by the original performance, we collected abstract observations while walking in the big city of Moscow illuminated by thousands of lights and advertisement panels, observing the contours and colors of contemporary design. The new mode of life in modern cities with their inhabitants and the instruments and objects they use and their expanding existence in the virtual media space became the new aesthetic model or, if you wish, the new exhibition with urban sketches inspiring our work. 


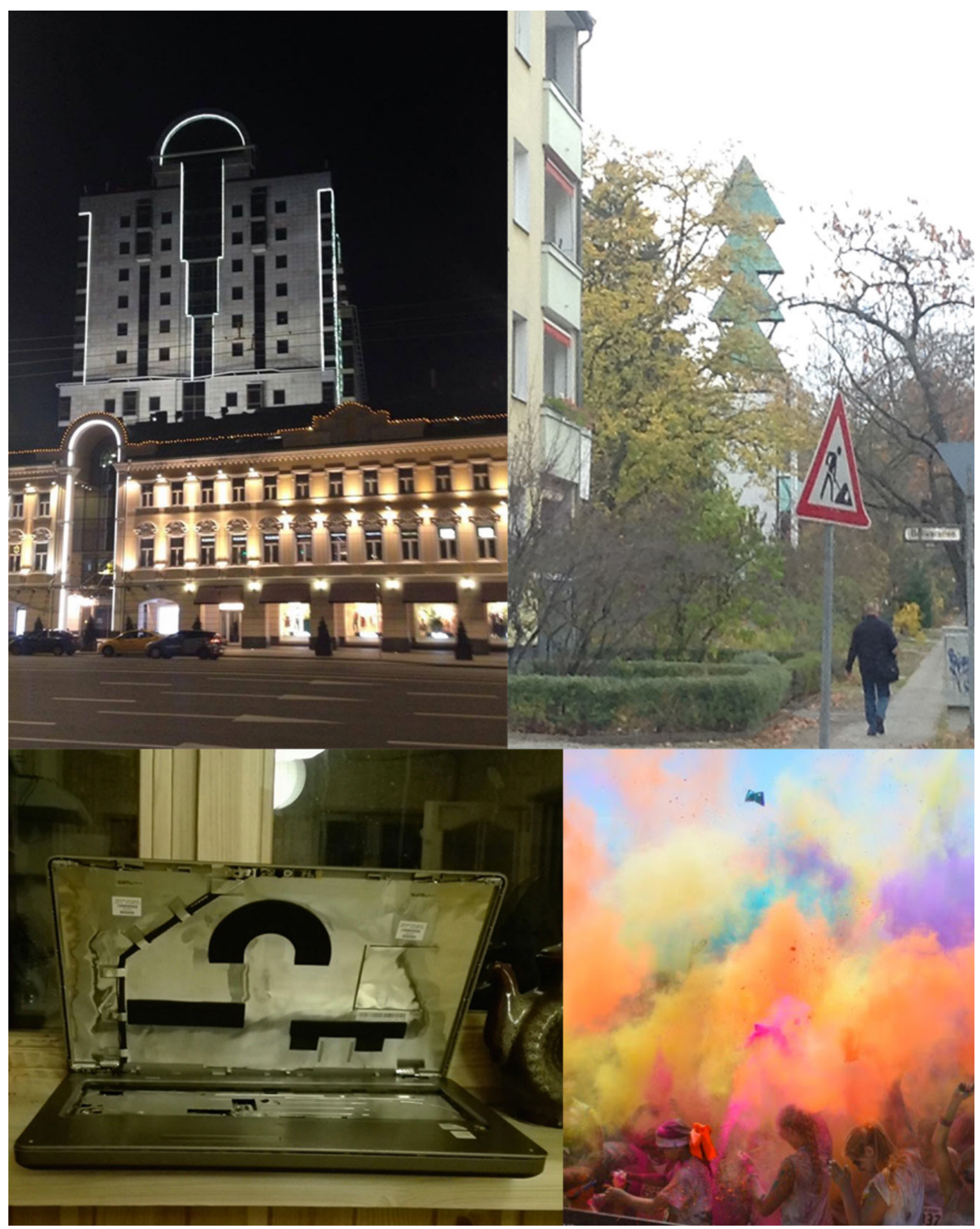

Fig. I Photocollage with examples of urban abstraction. 
In this way, the kaleidoscope of Tuileries was related to a techno/rave environment, while the two Jews in the scene Samuel Goldenberg and Schmuyle turned into a pair of traffic lights with the outlines of a policeman and an intellectual. A new musical structure was conceived to correspond to this vision.

After all, a lot of time has passed since Kandinsky staged his spectacle and even more since Mussorgsky's and Hartmann's period of deep research into national style and the Russian revival in art. In the 1910s, for example, the Russian Seasons caused a veritable scandal in the theatres of Paris and all around Europe by presenting stage dances inspired by pagan Slavic rituals, such as Nijinsky's choreography in The Rite of Spring. A reconstruction of this ballet was shown in Paris in 2014 during the Centenary of Russian Seasons. A reconstructed part of it was also included in the introduction of the film Coco Chanel. Now consider the Russian motives in The Hut of Baba-Yaga, for example. The drawing of Hartmann's that apparently inspired Mussorgsky, and later Kandinsky, depicts the house of Baba Yaga, a witch in the Slavic folklore tradition, who flies standing in a mortar and pushing herself in the air with a long pestle and lives in a house in the woods that stands on chicken legs instead of a foundation. In the past, people may have reacted to this image by quickly making the sign of the cross. However, today this character has lost a lot of its inner power. So, during the creation of the new scenography, there suddenly appeared this enigmatic old television image that still exists in every Russian home and continues to attract our eyes to an unreasonable extent. And, although not many people noticed it, the screen clock was the clock of the Kremlin tower, which serves as the time standard for the country.

The structure of the performance was founded on Kandinsky's reflections in his theoretical article On Stage Composition (1911). In the article, Kandinsky
Fig. 2 The Hut of Baba-Yaga in Planet Kandinsky 2017. Photo by Alexey Kopashov. gave a visual scheme that explains the relationship between the three main elements of the composition: sound, color and movement. The movement of each of these elements is shown on a drawing with the help of separate lines. Each of the three has its own, independent trajectory, different from the others, which illustrates the independent, inwardly integral dynamics of its development in time. In some places these lines momentarily cross to structure the composition. In 1923, Kandinsky wrote in his essay Abstract Synthesis on the Stage:

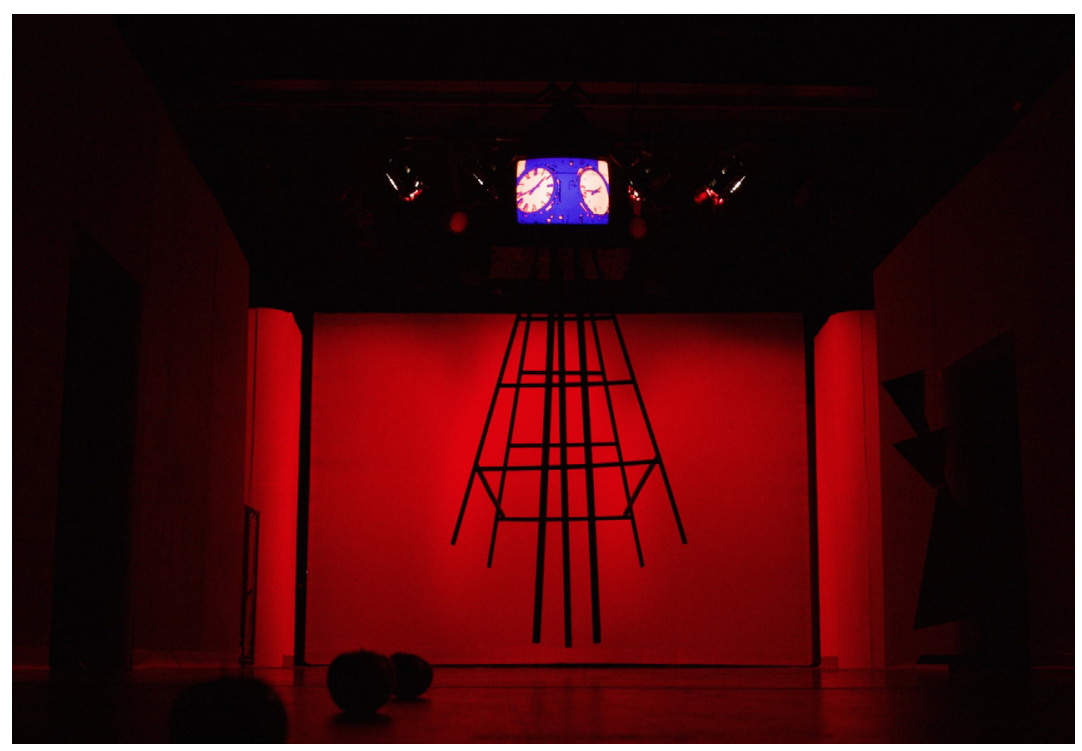


Stage:

1. Space and dimension - the resources of architecture - the basis that enables each art to raise its voice, to formulate joint sentences.

2. Color, inseparable from the object - the resources of painting - in its spatial and temporal extension, especially in the form of colored light.

3. Individual spatial extension - the resources of sculpture - with the possibility of structuring positive and negative space.

4. Organized sound - the resources of music - with temporal and spatial extension.

5. Organized movement - the resources of dance - temporal, spatial, abstract movements not of people alone, but of space, of abstract forms, subject to their own laws.

6. Finally, the last form of art known to us, which has not yet discovered its own abstract resources - poetry - places the temporal and spatial extension of human words at our disposal.

Just as sculpture is partially subsumed by architecture, so poetry is partially subsumed by music. Thus, strictly speaking, the purely abstract form of the theatre is the total of the abstract sounds:

1. of painting - color

2. of music - sound

3. of dance - movement

within the general sound of architectonic form.

You will notice that Kandinsky uses at each point the words "spatial and temporal extension" ("zeitliche und räumliche Auswertungen"). This apparently simple and obvious definition of the essential parts of a theatre action offers a special vision of space and time; it describes the instruments by which one can model these two extensions. In the theater, I think there is no better word for this than the rhythm of a performance. Let me now write more specifically about each of these three elements on the stage in Planet Kandinsky.

\section{PAINTING - COLOR}

We wanted to place the action in an undefined, colored, architectural "space and dimension" and leave the spectator without 3-dimensional points of orientation in space. On the stage, a pavilion was constructed instead of traditional stage masking. The usual theatrical black drapery was replaced by a light gray-colored front wall, side walls and a rug - all constantly 
illuminated during the show by colored light. The set had to create the effect of full immersion saturated in one infinite color. This effect was reinforced by the front wall's moving along the stage on a wagon. The pavilion increased slowly in depth during the performance. Three portals in succession: a circle, a triangle and a rectangle. The movement of the wall began in front of the pavilion behind a portal -3 meters in diameter, a flat, light circle. Then, during the performance, the wall moved and at the end reached a depth of 12 meters. This shift from two dimensions to infinite space happened slowly, so as to remain unnoticed by the viewer. It was an installation in which theatrical action took place. We took a particular interest in the color spaces of James Turrell and Carlos Cruz-Diez but also in the monumental light installations of the Olafur Eliasson studio. The idea of losing the sense of space by immersion in color is not new. Pyotr Laden gave a lot of importance to the experience of color perception; he also took into consideration the artistic approach to the studies of human psychological perception: such phenomena as the Ganzfeld effect, the entropic effect of the blue field, the phenomenon of "the prisoner's cinema," the post-image, etc. - all of which have been studied by many scholars and artists in recent years. We selected a running order of "colored light" in such a sequence as would make the audience interact not only with real forms and colors but also with images that form exclusively in the mind of the viewer influenced by a continual color presence. Kandinsky did precursory work in this field by concentrating a lot in his writings on the relation of color and form, and by dividing them. In order to show this relation we constructed the three geometrical portals.
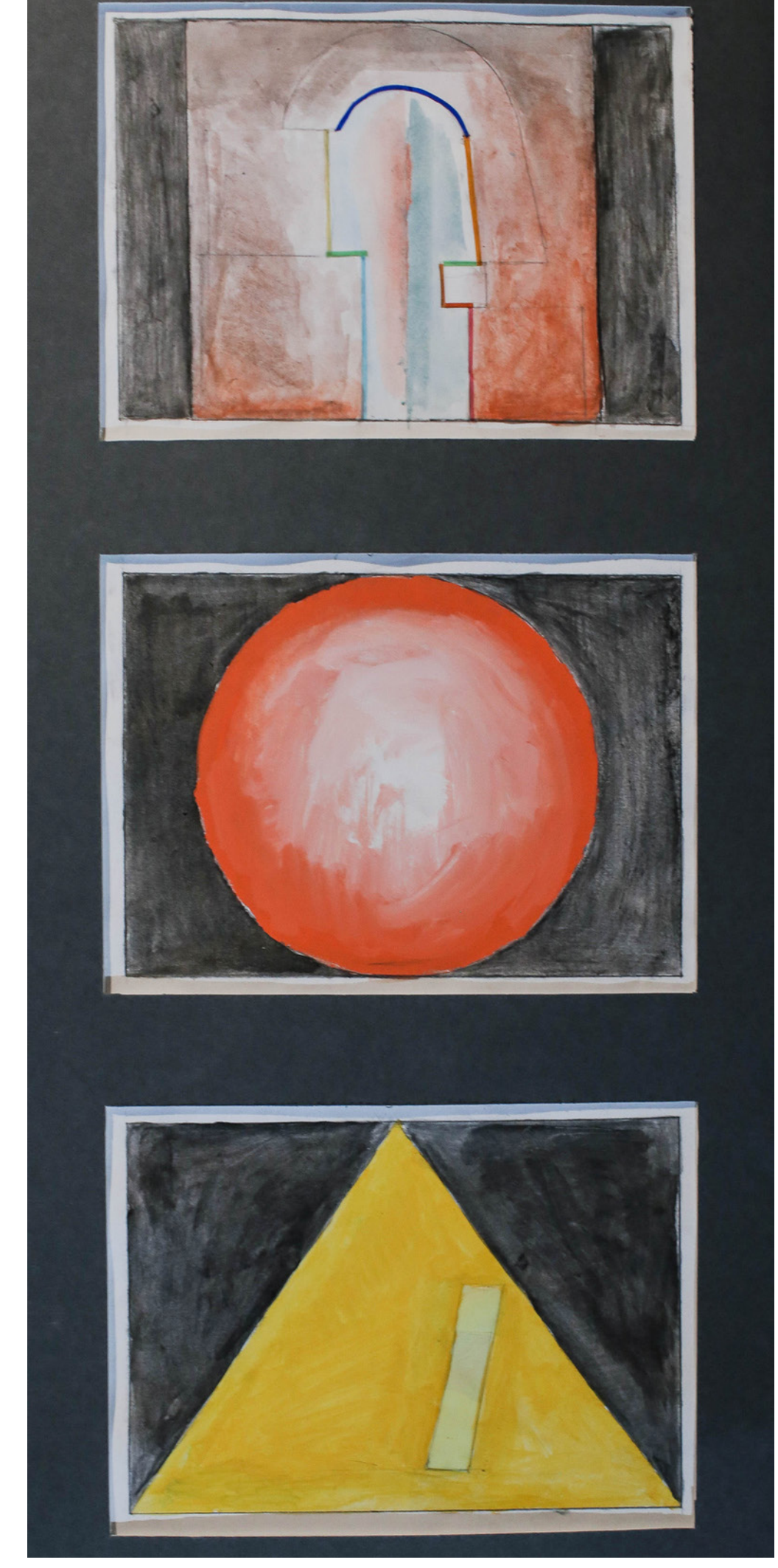
A great amount of luminosity and lighting design was introduced into the set. In Catacombae, inspired by the artwork of Dan Flavin, we simply used his neon installations.

The introduction of contemporary artworks into the set design was intended as a way to investigate the effect of contemporary kinetic and light installations. Combining elements of the historical (Russian, Western European and especially German) avant-garde that are reinterpreted in the broad context of $20^{\text {th }}$

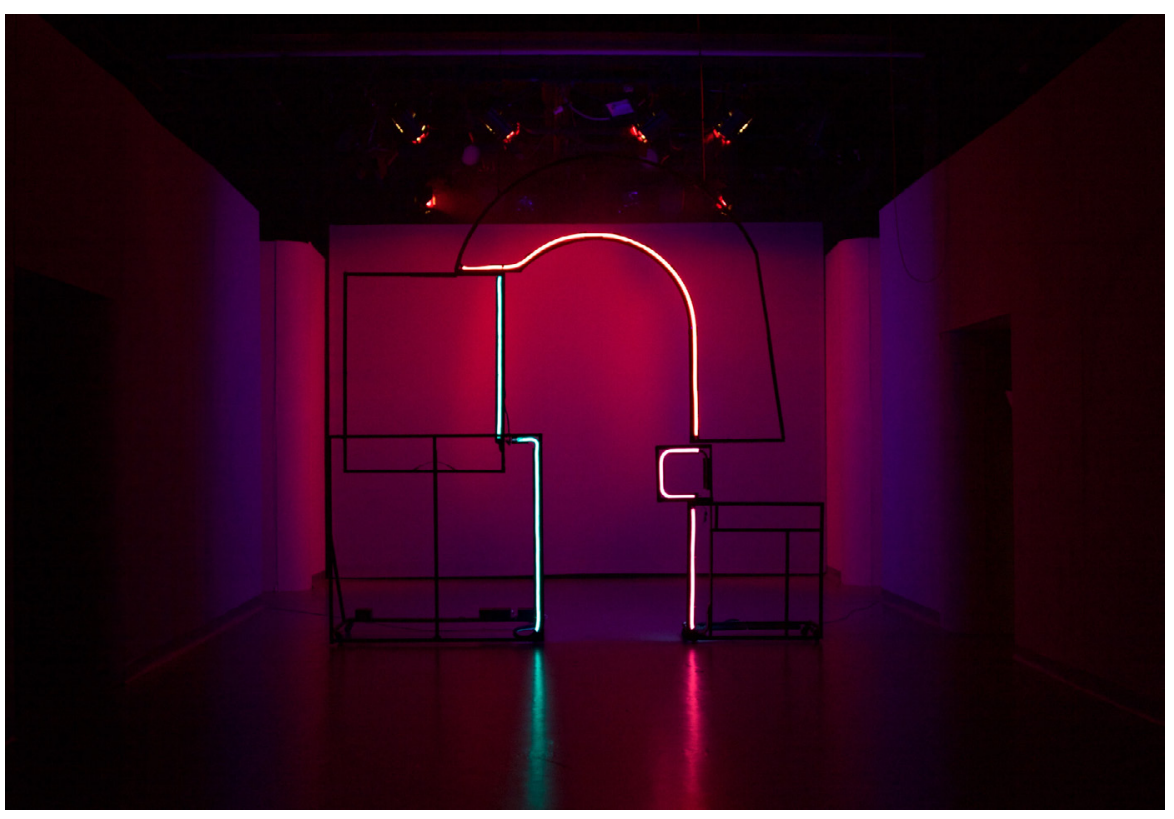
and $21^{\text {st }}$ century stage and visual art, the production strove to introduce the general public to the broad horizons of the leading international contemporary art.

Another interesting topic was the study of the image. Angelika Weißbach has published Kandinsky's notes for the lectures he gave at the Bauhaus in Weimar, Dessau and Berlin, (1922-1933); these show the importance he gave to a comparative approach to an image. He showed photos of the modern industrial age together with images of artworks of the past. Similar to what Aby Warburg did in creating the Mnemosyne Atlas, this approach is a way of abstracting the mind by correlating, through formal language and composition, highly different things and finding new resonances. Today, a similar "combining approach" appears in the increasing use of the media space, where artificial intelligence uses algorithms to put all data on the same level, thereby reorganizing the hierarchy of formal communication. This visual flattening was the aim of our new kaleidoscope concept, with all kinds of 3-dimensional objects floating in an infinite, computer-programmed space. Objects needed to be chosen from all kinds of machinery, animals, plants, instruments, toys, etc. Many of them were chosen from photos that Kandinsky used in his lectures. This concept was not realized and the video in the performance remained an unfinished draft version of it.

\section{MUSIC - SOUND}

We tried to create "organized sound," to make the musical and vocal environment help the public to abstract themselves from the boundaries of time and space. The composer for our project, Kirill Shirokov, has described for readers here his own work:

Fig. 4 Catacombae and Cum mortuis in lingua Mortua in Planet Kandinsky 2017. Photo by Alexey Kopashov. 
In the Pictures at an Exhibition I worked with the original score by Mussorgsky, searching for individual approaches to the composer's preparation of the original pieces. So there are a few scores that are reduced pieces by Mussorgsky, and some verbal scores for pianist on how to play the original scores by Mussorgsky. The point of this work is to study how Pictures at an Exhibition may be translated and organized inside the plural language of new music but not destroyed in some dramatic dimension.

With the purpose of diversifying the musical language I added some external material inside the score, such as DJ-sets made by Sasha Elina, very quiet flute drones, and three songs for solo voice with poems by Wassily Kandinsky. So the whole is both eclectic and unified in some way. The paradoxical meaning of the whole work (where reconstructed materials are closely connected with added pieces) is maybe the most interesting for me. Things seem to be alive inside of the performance, setting up and dissociating inside the composition. And the whole musical work is maybe more conceptual than spectacular, so each person may construct her/his own holistic entity, playing with whimsically neighboring elements inside of the personal perception.

The plurality of the musical arrangement achieved the sense of the transient that served as the basis of the performance.

Kandinsky's abstract poems were sung slowly with a faint, gentle voice accompanied by the long blasts of a flute that the composer mentioned. Kandinsky didn't use words in his original production. So singing his poetry was a major addition to the score. The idea was based on the feeling that there is a presence of the painter in the show: the pictures of the original production - the living paintings are composed in front of the spectator but there is no painter with a brush in his hand, no creator to be seen who moves and directs the colors to "paint" the composition. He is perhaps somewhere on the other side of the set design. At this point, I recalled experiments with illuminated painting on transparent glass, which we had organized with a group of stage design students of MKhAT School in the autumn of 2016. In an unlit room there was a piece of glass, installed vertically. Artists were dressed completely in black, including black gloves. In the dark, only the glass and the brush of the painter were lit from the side of the glass. The music began, and the painter painted his feelings about the melody, while on the other side of the glass another person - the observer - saw in the 
dark only the lit brush and the painting composing itself. The brush itself only appeared as a small, moving ball. The observer felt able to penetrate the thoughts of the artist and became his accomplice, a painter. This experiment was filmed (although this cut of it does not fully allow us to see what I have just described): https://www.youtube.com/watch?v=ZoktDqhs2mU

The voice of the painter in the performance can be found in the director's production notes Kandinsky wrote in 1928. This is a unique document written by Kandinsky in German with a detailed description of every picture of the staging. In fact, to these technical notes describing the movement of the set pieces and lighting there are added, in some places, descriptions of the sensations and emotional states they should convey:

... [T]he backstage is covered with a black plush curtain which creates a sense of immaterial depth.

Figure four sways slightly when moving. Figure eight is moving slightly in a wavelike manner. Figures 3 and 5 move abruptly. All figures must appear to be immaterial and fluttering.

This script also notes the spiritual insights of the performance. What we read in Kandinsky's notes gave us the idea to introduce a voice to the performance: the resounding voice of an invisible creator. The composer and Sasha Elina prepared these poems "placing the temporal and spatial extension of human words at our disposal." There is a strong emotionality behind the words of Kandinsky's poem. This emotivity was transmitted in a very calm voice, expressing the states of mind behind what was happening on stage.

Finally the last element of the "organized sound" of the performance was the orchestra of objects. Kirill Shirokov created a special sound orchestra based on the objects on stage. The actors created sounds through little microphones installed in the side walls of the pavilion. This part of the music engendered a micro characterization of the abstract world, but also played an important role in the actors' performances.

\section{DANCE - MOVEMENT}

Kandinsky's Pictures at an Exhibition had no actors except for a dance scene in The Market of Limoges and a pantomimed scene with two shadows in Samuel Goldenberg and Schmuyle. The introduction of the actors was a problem yet quite an engaging part of our work. Oskar Schlemmer, the director of the theatre workshop at the Bauhaus, wrote: 
Man, the animated being, would be banned from view in this mechanistic organism. He would stand as the "perfect engineer" at the central switchboard, from where he would direct this feast for the eyes. (...) Man and Space. Each has different laws of order. Whose shall prevail? Either abstract space is adapted in deference to natural man and transformed back into nature or the imitation of nature. This happens in the theater of illusionistic realism. Or natural man, in deference to abstract space, is recast to fit its mold. This happens on the abstract stage.

In Planet Kandinsky one sees four dancers. Once they enter the Abstract Space, a volumetric, semi-transparent, monochrome cape appears, as an image of a person in an abstract environment. Each actor has a color that characterizes him, and travels through this abstract environment in pursuit of mind-body harmony. Contrary to Schlemmer, the influence of human and abstract space is, at a certain moment, reciprocal here. The characters also serve as mechanics-puppeteers that start to arrange their surroundings for their performance.

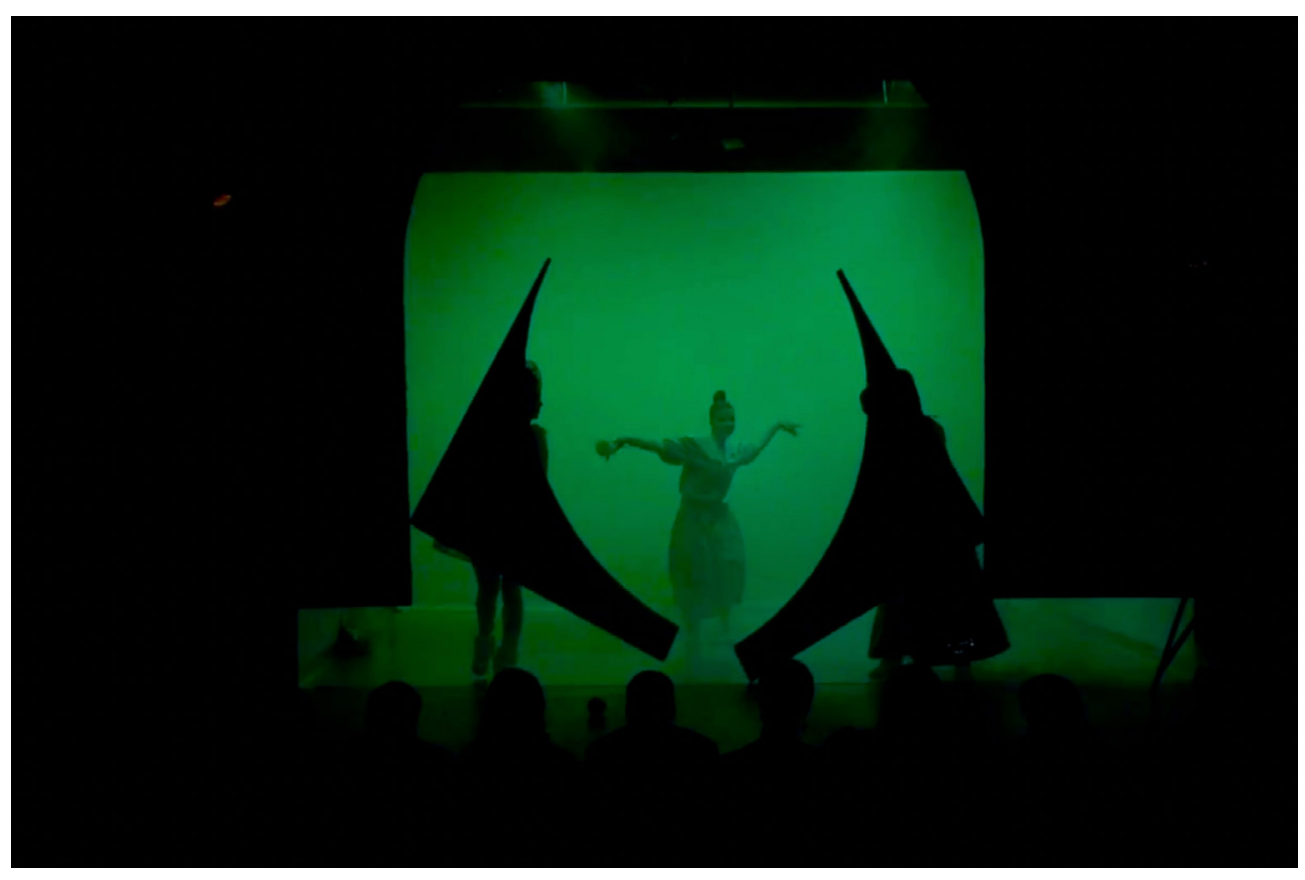

Fig. 5 Portal change, Planet Kandinsky 2017. Screenshot.

But the actor does not really control what happens because he starts to identify with the object. This was a way to investigate the opposition of the living and the non-living, the material and the non-material, the person and the object. The dancers constantly switch from being puppeteers to being images of moving, mechanical color forms, and then back.

The concept of the actor's existence on the stage was ambitious, and unfortunately we had only two days of technical rehearsals and three days of intense, hard, breathless run-throughs. So this also ended up as a more or less draft element of the final version. The organizational limitations did not offer space for experiment. However, this did not stop us from continuing our research and, after many trials, we came up with the idea of creating four generalized characters of urban inhabitants based on a multiplicity of cultural 
movements of the last decades. Each of these four characters had a main object (flower, Rubik's Cube, hairbrush, etc.) that defined his psychological type and conditioned his way of behaving. Maybe it came from the idea of revealing spirituality through inanimate objects. The actors' movements had to be created in relation to the biomechanical essence of their main object. These objects also served as the sound orchestra. It was a performative approach to working with an individual. Pyotr Laden collected a large range of references, taking many famous performers as models, including Joseph Beuys, Ana Mandieta and many other artists of different artistic movements of the 2oth century, such as minimalism (the synthetic spectacle Dance, 1979; composer Philip Glass, choreographer Lucinda Childs, stage designer Sol Levitt). We were inspired by dandies in the Moscow Underground, and by Kandinky's play Violet Curtain. But without a rehearsal space to experiment in, we couldn't achieve a balance between performative and more traditional approaches.

As I continued to think about these topics, I realized that the plastic, volumetric capes were impenetrable and did not offer an organic transformation in abstract space. Maybe we had thought too much about a materially minded planet that was hypothetically toxic and "not convenient for living." This seemed to me to have been a sign of fear of real contact with the abstract, which, it should be said, is not a locus that can be really materialized. For this reason we continued to search for costume solutions that would have transformed during the spectacle.

Be that as it may, within the time limitations, the team did great work. I should mention here the high level and professionalism of the actors graduating from MKhAT School, under the direction of Pavel Danilov and Maya Orchin. They did amazing work, learning a solo dance and two group dances each, in three days, and then improving them in the following three days of presentations. Planet Kandinsky was shown only twice, Nov. 25-26, 2017). As the dances simplified, they resolved in turn many problems of the actors' work. American choreographer, Maya Orchin, talked about her work for this essay:

I was trying to have each character have their own distinct movement quality, almost a slight exaggerated persona and then be affected by the world they entered. I feel that more could have been done and the movement could have been developed deeper if there was more time to work with all of the artists. My favorite section was the group movement-the intense physicality and partnering brought something slightly electric to the show which gave that part a jolt of energy. I would have loved to push it much further and if I had the chance to work on it longer I would have made it much wilder and bizarre. 
The "organized movement" or rhythm differed from the 1928 version in the continuity that we tried to maintain instead of cutting the "pictures" with blackouts. These pauses were replaced with the visual deconstruction of the picture. Each scene ends with a moment when the light is at its brightest, and the set and actors create the final composition of the picture - "the moment of pure emotion." Subsequently, this "sacral moment" (as we called it) or rhythmical pause disappears under the impact of "practical" movement. The stage pictures that were in the original performance can be divided into two major categories: some, such as Küchlein, Bydlo, and Limoges are concentrated on dynamic play. Others are more monumental and static: Gnomus, The Old Castle, Catacombae, and Kiev. These scenes follow a clear rhythm and structure: black - successive formation of the set composition - final composition and lighting effects - black. The taking off or striking of the pictures is not a part of the performance. From the beginning I was interested by the "dismantling phase" of the sets. We wanted to investigate this mysterious black backdrop with its "immaterial depth."

The spiritual specificity of the backstage area was confirmed later when I had the chance to participate in the set up and rehearsals of the reconstructed production of Pictures at an Exhibition that will be presented at the Centenary of the Bauhaus in January 2019. The set design for the reconstruction is the same as in 1983. It is directed by Horst Birr (colleague of Martin Rupprecht) and Stefano Laudato, head of the Italian team from the Teatro Nuovo Giovanni da Udine, where the set design has been conserved since 1983 and used for student performances on various occasions. I noticed that the backstage workers have a far more important role than it may seem at first: they have a really inspiring task in the original play. Once the technical run-through, coordinated with the music, was done, the backstage workers were asked to move the set elements with emotion, according to the description in Kandinsky's notes. Every movement follows the music, and starts with a set piece hanging from a string and the hand that holds it. Just like an actor, the set piece makes its first impression as it appears on the stage and then in its every movement. This is particularly important in a performance without actors. This is why in Planet Kandinsky we tried to bring these "offstage dancers" and their role to the spectators' attention. I think that the idea of "desacralization" lay in the wish to investigate the very nature of the abstract forms that you see in the original production. 


\section{TO CONCLUDE}

Planet Kandinsky was created on the basis of an important principle that was elaborated by Kandinsky and other "Bauhäuslers" such as Lázló Moholy-Nagy (Sketch for a Score for a Mechanized Eccentric, 1920), Oskar Schlemmer (Triadic Ballet, 1922), Ander Weininger (Sketches for Action to Surface, in the Mechanical Stage Revue 1926), Kurt Schmidt (Theatre sketches on paper and multi-layerd painted glass) and that was innovative and new to modern art: all artistic elements must be put on the same level. The color red does not carry more weight than the music does; a movement does not take more priority than a lighting change does. This purifies the approach to the stage and opens new rhythmical possibilities. As Kandinsky taught in 1932:

All together - anarchy on the surface, disorder, confusion, similar from the inside to fertilization: sweeping out of academism (= semblant life of external form), transition to a new basis (for example, the denial of Wölfflin's law), elimination of 'high' art, high themes, and 'high' material = synthesis, instead of clear, rigid language - the language of allusions, instead of feeling - feeling, inner experience, noises = abstract form ('unclear') (Kandinsky 2015, I: 414).

Our performance did not have an effective and functioning rhythmical construction. Many interesting ideas were not realized. The new urban motives remained expressed in a crude form, becoming somewhat disco-like at times. This was also noted by many spectators, who were surprised that the high spiritual art of Kandinsky could have been put on the level of a music nightclub. It is possible that our ideas did not find a convincing form of expression. As I observed people working with Kandinsky's Pictures, I noticed how different their relation to the abstract piece could be. The unclear and the undefined engender emotions in a certain way. A strong, emotional state of mind can be found in Kandinsky's texts, too. His theoretical texts and poems carry a special artistic tone. Going back to the beginning of our performance, in the Prologue the author's voice is introduced by the character of the Professor who recites passages from Kandinsky's theoretical yet highly poetic text Through the Wall, which treats the aesthetics of perception. It rapturously describes the creative process emerging in the artist's soul as a sort of mystic insight that experiences numerous shocks and deceptions on its way. It also examines the process of the viewer-listener's acquiring a new vision of things - one that he attains under the guidance of the artist, who teaches him to be sensitive 
to the surrounding world. In this way, the Prologue aimed to put the viewer in the appropriate mood and introduce him to the main themes of the production. The Professor is a blithe person. He has already been in the Abstract World and is Kandinsky's alter ego of sorts. And it seems as if he tries to depict what the world there is really like. This Prologue was conceived to encourage the spectator to perceive the abstract spectacle, to form his own opinion through his unique experience - to complete his own, unrepeatable voyage. So I was very happy when a woman came up to me after the show and, after mentioning

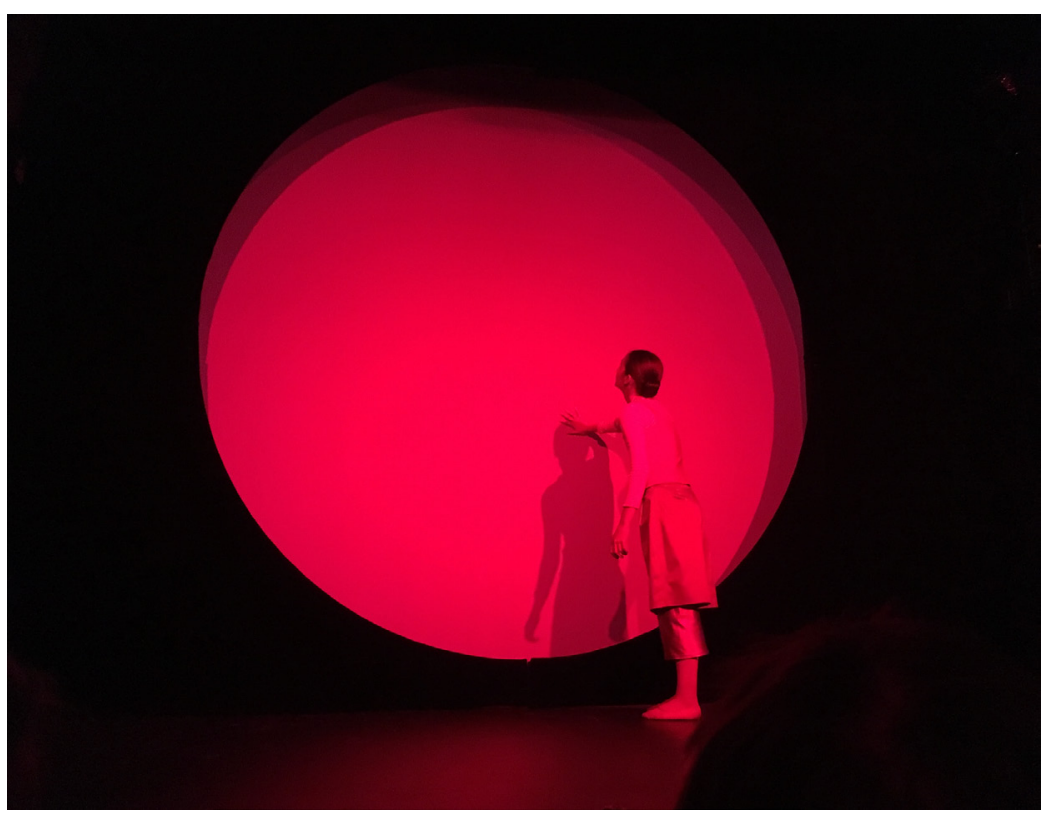

Fig. 6 Entrance of the girl into Abstract Space in Planet Kandinsky, 2017. Photo by Lorenzo Vinciguerra. her and made her understand something important about artistic expression.

For this reason, the first character who enters the Abstract Space is a little girl in reconstructed costume. Driven by curiosity, she gives the initial push to the moving wall that detaches from the 2-dimensional portal.

In contrast to adults, a child perceives the abstract figures purely. "A child, for whom every object is new, experiences the world in this way," writes Kandinsky in On the Spiritual in Art, comparing the child's perception with the perception of the artist. He writes about a "very simple movement, towards an unknown goal" that "produces of its own accord a significant, mysterious, and solemn effect." I would say that Planet Kandinsky creates a viable first encounter with abstract theatre and casts a mold that can be pushed much further.

\section{SELECTED REFERENCES}

Kandinsky, Wassily, Complete Writings on Art, ed. by Kenneth C. Lindsay and Peter Vergo (New York: Da Capo, 1994).

Kandinsky, Wassily, Du théâtre / Über das Theater / O meampe, éd. Jessica Boissel (Paris: Société Kandinsky, 2007).

Kandinsky, Wassily, Unterricht am Bauhaus 1923-1933. Vorträge, Seminare, Übungen, zusammengestellt und bearbeitet von Angelika Weißbach, Band I-II (Berlin, Gebr. Mann), 2015.

Schlemmer, Oskar, "Man and Art Figure," in The Theatre of the Bauhaus, trans. German edition of 1925 (Wesleyan University Press Middletown Connecticut), 1961. 


\title{
8. INTERNATIONAL CONFERENCE, "KANDINSKY AND THEATER- PERFORMANCE," MOSCOW 2017: DIALOGUES WITH CHARLOTTE BEAUFORT, SERGEI LOBANKOV AND ANNA KONSTANTINOVA Nadia Podzemskaia
}

\begin{abstract}
One year after an International conference, "Kandinsky and Theater-Performance" in Moscow, one French artist, one actor of the Theater of Giedrius Mackievičius and one theater critic from St. Petersburg share with us their thoughts about Kandinsky's contribution to the development of today's performing arts.
\end{abstract}

Keywords: Visual arts. Robert Wilson. Turrell.

\section{RESUMO}

Um ano após a conferência internacional Kandinsky e o Teatro-Performance que ocorreu em Moscou, um artista francês, um ator do Teatro de Giedrius Mackievičius e um crítico teatral de São Petersburgo compartilham suas ideias sobre a contribuição de Kandinksy para o desenvolvimento das artes performativas.

Palavras-chave: Artes Visuais, Robert Wilson, Turrell.

In 2017, I organized an international conference entitled "Kandinsky and Theater-Performance. Dialogues with Contemporary Art" (Nov. 25 - 26, Ateliers of the Chekhov Moscow Art Theater). The project stemmed from my desire to acquaint the Russian theatrical and artistic communities with Wassily Kandinsky's work for the stage and to interpret it from the standpoint of contemporary theater and visual arts. I took inspiration from the exhibition "Musicircus. Masterpieces from the Centre Pompidou Collection," which took place at the Centre Pompidou-Metz in 2016 - 2017. In a paradigmatic way, the exhibition began with Kandinsky and ended with Robert Wilson.

The situation in Russia is quite paradoxical. With the exception of a stage composition under the name of The Yellow Sound (which was set to music by Alfred Schnittke for a production based on Kandinsky's theories rather than on his actual text, staged by Giedrius Mackevičius in the 1980s), Kandinsky's work for the stage remains little known in his native country. His texts on theater were published in full in Paris at the end of the $20^{\text {th }}$ century. However, 
these publications, and in general Kandinsky's staging ideas and principles, are almost unknown in Russia, including by theater people. Indeed, the Russian tradition of constructivist theater does not include Kandinsky. At the same time, already by 1915 his theatrical ideas were being absorbed by the Zurich Dadaists (Hugo Ball, Hans Arp, and Sophie Taeuber-Arp).

In Germany, a systematic engagement with the theatrical heritage of the 1910s and 1920s that began in the 1980s and 1990s and included the Bauhaus theater (cf. the reconstruction of Schlemmer's Mechanical Dance), led to a profound renewal of the formal language and the proliferation of different forms of theatrical experiments. The work of the Düsseldorf Theater's "Klänge" is a case in point. Many of its productions are the result of an improvised, short-term cooperation between the composer and the choreographer (and video artist), continuing the experiments begun by Kandinsky in 1908 and 1909 in Munich, with the composer Thomas de Hartmann and the dancer Alexander Sakharov.

It is no coincidence that Kandinsky's partners in his first "stage compositions" were "Russian Müncheners," insofar as the sources of his theatrical experiments were linked to the rapid development of theater in Russia. It is known that Kandinsky had intended to invite Meyerhold to direct a production of The Yellow Sound in the early 1910s. Similarly, on the eve of WWI, he prepared a Russian edition of his Poems in Prose (published in 1912 in Munich in the book of poems and prints Klänge) in the art salon of sculptor Vladimir Izdebsky in Odessa, and his theoretical treatise On the Spiritual in Art with the Moscow publishing house, Iskusstvo. All of these projects (which were not realized on account of the outbreak of the war) show Kandinsky's desire to incorporate his multi-faceted work (painting, theater, poetry, theory) into the context of Russian art with which it was profoundly connected. This deep tie with Russia was fully felt by the audience of his production Pictures at an Exhibition in 1928 in Dessau, who compared it with Tairov's theater.

While the deep connection of Kandinsky's work with Russia was noticeable to the German audience and obvious to the artist himself, within Russia this was systematically denied. So it was before WWI, so it remained after the revolution, when Kandinsky lived in Moscow until 1921, and this obviously continued in the Soviet period. When Kandinsky's art finally came back to his native country at the end of the Perestroika era, the need to incorporate it into the context of Russian art called for a specialized and still unfinished study of his relations with Russian artistic and intellectual movements. Indeed Kandinsky, who mostly worked abroad, debunks many common stereotypes about Russian art (the history of the publication of two of his poems from 
Sounds in the famous Futurist work A Slap in the Face of Public Taste, where they were largely out of place, is quite telling).

Generally speaking, we have to keep in mind the special position of Kandinsky, whose work lies at the intersection of Russian, German and French culture. It makes his art especially interesting and rich, and fundamentally open to those who are ready to abandon their one-sided, narrowly professional and narrowly national vision and are available to have a dialogue with people from other fields, specializations, and cultures.

For the conference, I curated a booklet with a selection of materials from it (Nov. 2017). Almost one year later I have asked several contributors to the booklet to share their thoughts on the main issues that were raised in Moscow.

○

Charlotte Beaufort (artist, senior lecturer in the visual and performing arts at the University Picardie Jules Verne, Amiens) came from the theater as a lighting designer to university research and artistic work with light as an independent artistic medium. In this sense, she took an opposite path to Kandinsky's.

\section{KANDINSKY'S STAGE COMPOSITIONS \\ AND THE PERFORMING ARTS \\ Charlotte Beaufort}

The visual arts and the performing arts have always interacted, as has been especially the case with painting and scenography ever since trompe-l'œil and foreshortening perspective were used for backdrops. Studying such transartistic interactions becomes even more interesting in the more radical context of $20^{\text {th }}$-century avant-gardes revolutionizing artistic forms and theories. While Matisse, Chirico, Picasso, Delaunay, Chagall and many others did show interest in the performing arts, Kandinsky stands apart.

In this context of an anti-academicist rejection of tradition and representation, Kandinsky stands out as trying to devise an autonomous visual language based on the rethinking from scratch of the non-referential use of line and color. Like forms, colors are now freed from all figurative goals, they become autonomous and only obey their inner laws. Under the influence of Goethe and Steiner, Kandinsky focuses on color's specific and forcefully evocative power, as famously experienced by him in the "magical houses" of Russian rural art where form and color were disconnected from 
any type of meaning as interiors and furniture were all painted in vivid colors unrelated to their functions.

Since music and the performing arts were instrumental in Kandinsky's choice to devise his own visual language and theory, one must focus on why, between 1908 and 1912, he chose to devote some of his time to a possible change of instrument, as he said, by exploring the possibilities of abstract stage compositions. (I will only deal here with these works, not including Pictures at An Exhibition, 1928, which differs from the earlier compositions, firstly because it was commissioned, secondly because it was a musicalist attempt to 'transcribe' or 'translate' a preexisting musical piece into a painting.)

Kandinsky's taste for music and synesthetic experiences of sound and color, incented him to think about painting in terms of the pure and abstract composition of form and color. Thanks to his interactions with composers such as Thomas von Hartmann and Arnold Schönberg between 1909 and 1914, he discovered with music that an autonomous, non-referential and nonnarrative language was possible. After a Schönberg concert in 1911 revealed to him how similar to this music his painting was, Kandinsky and Schönberg started to correspond - most notably about the questions raised by the passage from figurative to "abstract" painting and from tonal to atonal music.

It must be noted that since the 1870 s and 1880 s, the modern theater was undergoing its own radical evolutions and refoundation under the impulse of directors, stage designers and essayists Adolphe Appia and Edward Gordon Craig. By the early $20^{\text {th }}$-century, the theater had become the place par excellence where the arts interacted and became one under the influence of Wagner's Gesamtkunstwerk. As electricity developed, lighting fixtures became more powerful and sophisticated, and light became a more autonomous medium, making it easier for actors to move on stage and allowing light designers to create stage volumes allowing to do away with painted backdrops. Thus light became such a decisive element in the creation of scenic space and of visual impressions that it began to be perceived as a full-fledged actor on stage. As Robert Wilson, both a visual and a performing artist, later confirmed in a 1994 interview, "Light is not an afterthought. It's something that's architectural, it's structure, it's thought about from the beginning, it's part of the book, it's like an actor. So it's not a decoration" (Wilson 1994).

For indeed one must stress that artificial light seems to have been a key common element in both these revolutions in the visual and the performing arts. Robert Delaunay, contrary to Kandinsky, was a stage designer before he became one of the major figures in the history of abstract painting, but one finds in his writings elements that may remind us of Kandinsky's reflections 
upon color - as when he wrote that, "The line is the limit. Color provides (non-perspectival, non-successive, but simultaneous) depth, its form and its movement." For Kandinsky, color is not limitless and needs form, but color comes first, color is given first for its sensitive qualities, it blooms out of an inner necessity and is the most direct expression of the spiritual — which the artist ultimately shapes into form (external necessity). Form follows color.

The performing arts helped Kandinsky test his thoughts on color. The stage allowed him to work on a large scale in real three-dimensional space. The use of electric lighting on a dark stage allowed him to play with colormatter and light-color. Kandinsky's stage compositions are temporal works for movement, sound and color (color-matter and light-color), three-media scores for one and only voice. Colors take forms and become alive as they evolve and vibrate in the changing and colored lighting and as anonymous and un-individualized color bearers move across the stage and proffer inarticulate sounds. Colors, movements and sounds resonate together as the synthetic vibratory expression of the artist's soul or inner sonority meant to trigger the receptivity of the viewer's own soul.

Time and movement are essential to Kandinsky's paintings and stage experiments. For Kandinsky, art like religion is based on spiritual principles and aims at spiritual elevation and progress. He wants his paintings and stage compositions to be experienced by the viewer like Russian or Byzantine religious icons. The progressive unveiling and the lifting of appearances need to be experienced in time.

To Be Sung, a chamber opera composed, directed and adapted from Gertrude Stein's libretto (A Lyrical Opera Made by Two) by Pascal Dusapin in 1994, with scenography and light by Californian artist James Turrell, is in many respects a modern realization of Kandinsky's project (Turrell 1994). In a limitless space filled with an almost imperceptibly changing mist of colored light chants rise and ghost-like figures seem to float, vibratory phenomena interact and merge into one visual and aural expression - Kandinsky would have called a Sonority. With no narrative structure and no predetermined meaning, this work is meant to be experienced as a moving picture.

And indeed the notion of a moving picture composed as a score of separate visual and sound elements that yet form a whole is a painter's idea, and it is no wonder that Robert Wilson, who best represents Kandinsky's heritage in the performing arts, actually was educated as a painter and an architect before he became a director and scenographer. As he said in 1997, "I believe above all in a formal theatre. [...] My scripts do not tell stories, they are constructed like real musical scores. All the characters' gestures are numbered, the rhythms 
of light and action are planned to the second, as in a score where light, sound and action converge" (Quadri, Bertoni, Stearns 1997: 35-36).

While the performing arts greatly contributed to Kandinsky's development of a plastic language, his stage compositions were animated pictures that remained closer to the visual than to the performing arts because they were the products of a painter's explorational quest. Music allowed Kandinsky to understand and imagine what a non-referential visual language could be, scenography made three-dimensional movement possible, theater and music allowed to include time in the composition, thus leading to the succession of tableaux, the multimedia polyphonic writing, and many explorations into the correspondences and dialogues between the visual and the aural.

To a certain extent, Kandinsky contributed to the development of today's multimedia art and he prefigured environments and installations. But as Robert Wilson's creations demonstrate, his stage compositions also prefigured major and successful developments in the performing arts.

\section{SELECTED REFERENCES}

Delaunay, Robert, "La lumière”, in Robert Delaunay, Du cubisme à l'art abstrait.

Documents inédits publiés par Pierre Francastel et suivis d'un catalogue de l'œuvre de R. Delaunay par Guy Habasque (Paris, S.E.V.P.E.N.).

To Be Sung, a chamber opera composed, directed and adapted from Gertrude Stein's libretto (A Lyrical Opera Made by Two) by Pascal Dusapin in 1994, with scenography and light by Californian artist James Turrell.

Quadri, Berlon, Stearns 1997: Quadri, Franco, Bertoni, Franco, Stearns, Robert, Robert Wilson (Paris, Éditions Plume).

Wilson 1994: Wilson, Robert, interview with John Bell, Theater Week (January 3).

During the conference, a special section was dedicated to different mises en scène inspired by Kandinsky's The Yellow Sound. This included a production based on Kandinsky's theories and realized in the 1980 by Giedrius Mackievičius in his Moscow Teatr plastičeskoj dramy. Sergei Lobankov was an actor with Mackievičius. I asked him what made the production inspired by Kandinsky's color theories different from other productions and how the actors worked out the plasticity of the performance.

Sergei Lobankov: By 1984, the Moscow Teatr plastičeskoj Dramy of Giedrius Mackievičius had already included in its repertory two performance productions associated with the fine arts, The Overcoming, about the life and work of the 
great master, Michelangelo Buonarotti, and The Red Horse, after the turn-ofthe century paintings by Kuz'ma Petrov-Vodkin, Edgar Degas, Robert Falk, Henri Toulouse-Lautrec, Renato Guttuso, Edvard Munch, Nikolaj Roerich, and Paul Cézanne. The chef-d'oeuvres of painting and sculpture inspired Giedrius and provided plots for his productions. An art lover and connoisseur, Mackievičius melded together the visual arts, poetry and music in his compositions. Working on the productions, he spent the preparatory period studying with the actors samples of artistic works from the epoch the script was about. From his teacher, graphic artist, mime artist, theater director and stage designer Modris Tenisons, he borrowed the habit of studying expressive acting by association with the fine arts. He used it with his own actors working with their imaginations.

Kandinsky's The Yellow Sound was not born as a regular repertory production. The composer Alfred Schnittke wrote the music starting from Kandinsky's libretto and approached Mackievičius asking him to stage the piece. Giedrius responded with pleasure to the suggestion, both unusual and attractive for several reasons. Firstly, the libretto was written by Kandinsky himself. Secondly, the music was by Schnittke. And thirdly, the performance would feature the ensemble of the Bolshoi Theatre soloists, implying that the Bolshoi musician and his own artists would appear together in a single performance space. Moreover, in some scenes, musicians and actors could interact with each other. Among the characters Giedrius created, there was the Conductor, and, through the performance, he was in contact with the real conductor. Live music, by contrast with recorded sound, was very special. After a while, though, we performed to a recording, as it was too complicated to coordinate the touring schedule of the two groups.

Thanks to this work, the actors got to know and even studied at length Kandinsky's theory of painting. Together with Giedrius, they read his work out loud during rehearsals, took notes and discussed the concepts, including the combinations and contradictions of colors and the combinations of color with sound. Improvising, we tried to express color, sound, shape as well as their combinations and diversity by our movements. It should be said that Giedrius had already had some experience in improvising with actors to abstract notions and shapes. This came from his experience of working with Modris Tenisons in the Kaunas Ensemble of Pantomime. Yet, in this case, the attempt to analyze and work out the material looked more serious and profound. At the end, the actors were prepared by the principles for the task of embodying abstract images in the work. On other occasions, they also had had an experience of performing allegorical and even mystical characters such as Death, Idea, Time, Eternity, Steppe, Star, God, Fairy, Psyche and so on. 
In 1984, under the communist regime and ideology (it was still the USSR), such stage performance was extremely innovative both in content and form. The spectator had not yet been taught to watch abstract, associative and expressive forms of movement. The audience was familiar with classical ballet, folk and ballroom dance, but it was not exposed to the contemporary choreography actively developing in the West.

Giedrius found his own vision of Kandinsky's libretto and interpreted it successfully. Using Schnittke's music, he developed what began as the drama of the The Yellow Sound into colorful and expressive shapes. By doing this, I think he realized some of Kandinsky's dream of a spectacle that would combine music, painting and movement.

Nadia Podzemskaia: The visual world of your performance, about which we can have an idea today through video recordings and photographs, is very far, however, from the painting of Kandinsky. We see in the photos very expressive figures, but there is little that is abstract in them. Maybe there is some detail that would show visually your work on the shape or color?

S.L.: There are not many photos left, especially in color. Looking at the

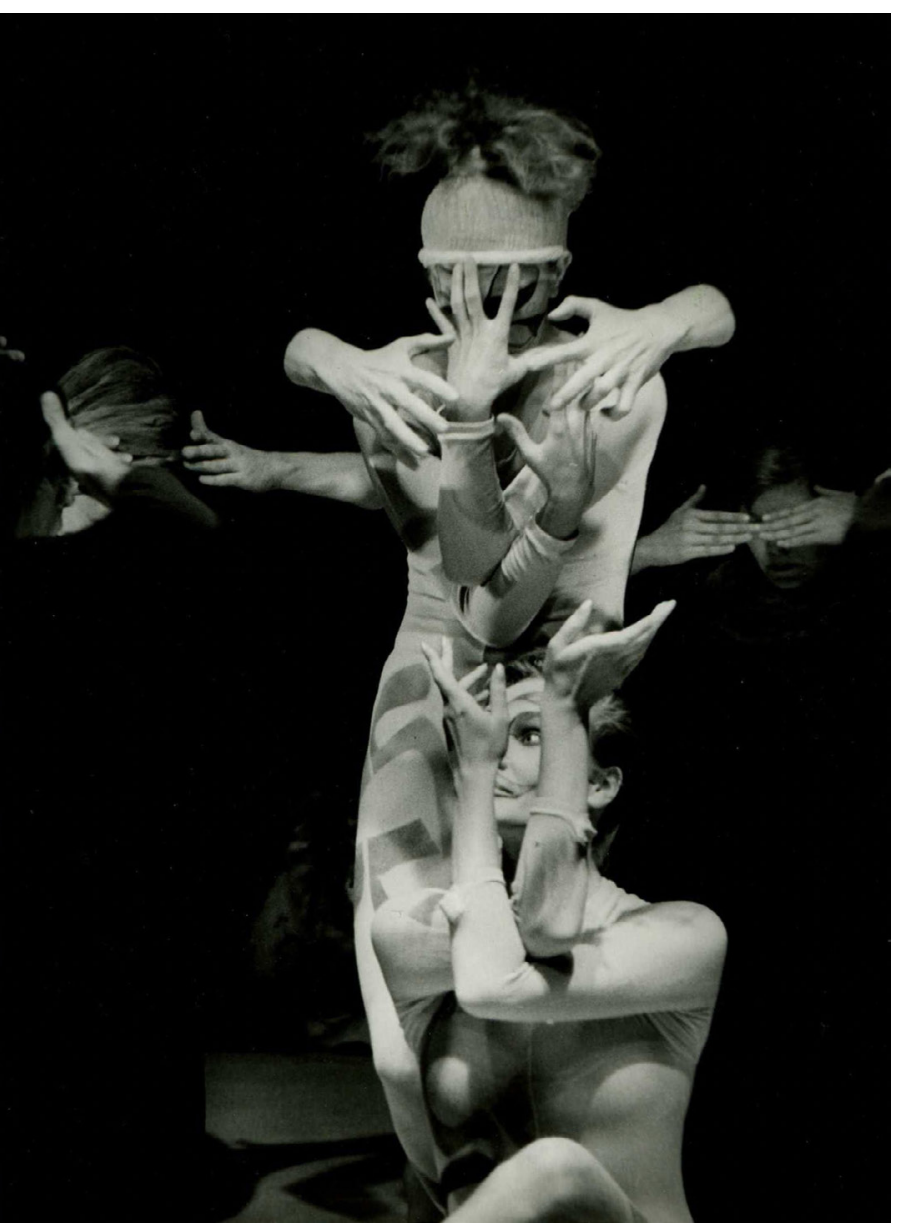

Fig. I The second version of the Giants' costumes (1985) remaining photos, one cannot say: Oh, this is Kandinsky! We did not reconstruct his painting with our bodies. Yet there was a fragment, recorded on one photo, with a part of an abstract geometrical composition. And the Yellow Sound was the Yellow Flower performed by two actresses. Their actions corresponded to the sound of two notes, La (an F) and Si (a G).

They had face make-up in the shape of a floral pattern, and on their yellow leotards there was something reminiscent of the colored figures from Kandinsky's compositions. Thus, elements of abstraction were shown in part through the make-up and costumes.

In the last costumed version (1989), the Giants wore yellow robes with fragments of Kandinsky's painting compositions on them. And on their heads they had yellow geometrical shape: cube, globe, cone, cylinder... There are no such photos, Fig. 2 Still shot (in robes), the third only a video of dubious quality.

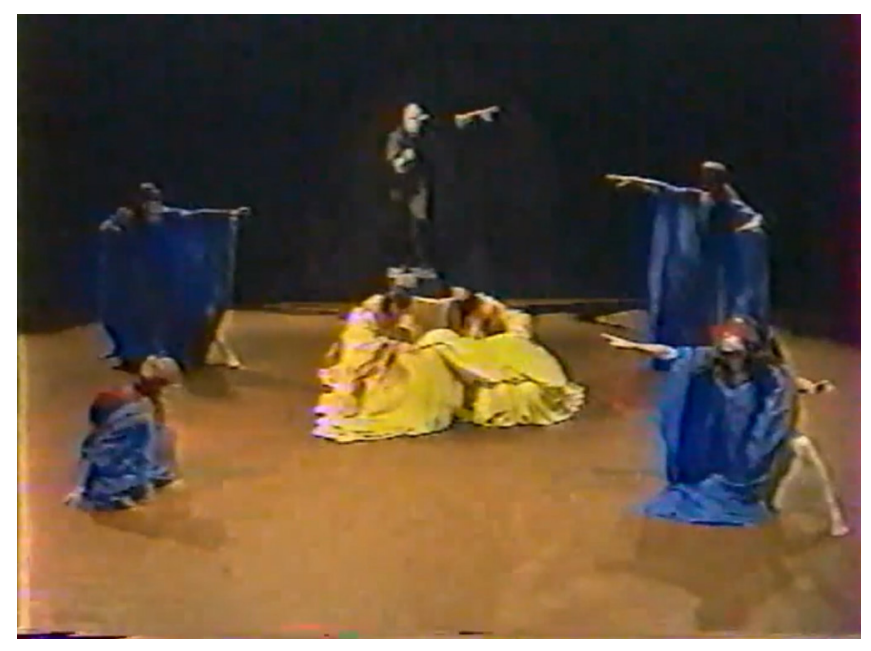
version of the costumes (1989) 
And other characters had robes of color but with no pattern. Only the Giants' costumes hinted at the paintings brought to live. At the end of the mise en scène, there was one more moving element of decoration, a very large piece of yellow fabric with which the Yellow Giants covered the stage, burying under it the participants who fought to liberate themselves. This was the triumph of the very active, aggressive yellow color (according to Kandinsky's theory of painting). And I would like to make clear that we did not play triangles, spots and lines of some color. In the movement, we rendered RELATIONSHIPS! As spectators, we are surely interested in shapes as such, yet we are interested even more in what is happening and in the impact we receive from interacting elements of various shapes. We are interested in conflict as the foundation of drama. That was what Giedrius taught us and wanted us to perform. For this reason, we could enact any material, most abstract and even absurd: we played relationships, and not concepts or shapes. This is the difference between theatre and the fine arts, where the form displays the essence, or between theatre and music, where sound directly expresses feelings. By contrast, theatre is about action.

Above I tried to formulate my understanding of what theatre is about in the case of The Yellow Sound, and I also tried to convey to what extent it was 'abstract'. I believe that for the mass audience, as opposed to the intellectual elite, there was more than enough abstraction in the performance.

N.P.: Could you please write more about costume changes during performances and about the use of make-up?

S.L.: Originally, we looked for make-up that would enhance and express the nature of the characters, but only for the Yellow Giants. They were five. Giedrius defined them as five vices: Fear, Anger, Lust, Pride and Greed. Besides the make-up, each Giant had characteristic details in the costume. For example, Fear had a linen overall suit, sack-like and hanging from the bottom (as if he had pooped in his pants), his hair made out of synthetic rope and standing on end, and rounded eyes. Greed wore a leotard with tiny bags and parcels attached to the belt (like purses with coins). On the head, there was a scarf with a twisted headband similar to that of an Arab sheikh. The make-up was in the shape of a grill behind which an avaricious man keeps his savings.

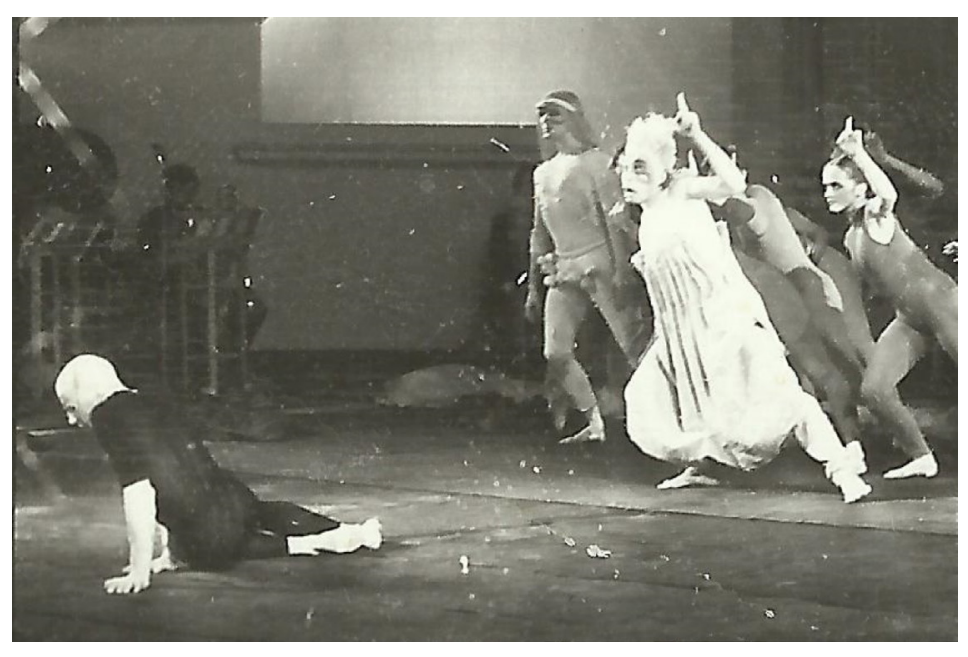

In the first version (1984), the Crowd (Cosmos, undefined creatures, people) Fig. 3 The first performance in was dressed in dark-blue overall leotards. January 1984. 
Further into the action, a long piece of red chiffon on the eyes was added for the red creatures that flew by. In another scene the Conductor distributed pieces of the light yellow fabric (as parts of the Yellow Flower-Sound), and the actors tried them on and took possession of the 'petals'. And later 'the crowd' and other participants came in running in leotards of different colors. The Conductor wore only the black overall leotard and the make-up of a white triangle with a black rim.

In the second version (1985), the Conductor added a tuxedo with a long tail and an epaulette on the shoulder (a hint of the dictator figure). Sometimes, instead of a white rectangle, the actor (Sergei Tsvetkov) added a mustache like that of Chaplin or the Fuehrer (a stronger hint of the dictator). The Yellow Giants changed details of their costumes from rough linen to gold brocade.

In the third version (1989), the Giants put wide yellow robes over yellow leotards and wore yellow geometrical figures with metal wire frames as headwear. The Crowd wore dark-blue robes at the beginning and later it changed into the robes of various colors with yellow headbands..

N.P.: The very last question. When Giedrius worked with you on The Yellow Sound, what text of Kandinsky's did he use? Did you use the text of the libretto, and did you, at the same time read On the Spiritual in Art? Since at that time, in the USSR it was almost impossible to find Kandinsky's texts.

S.L.: I cannot say anything about the sources. At the rehearsals, Giedrius read us the libretto out loud. And he talked about Kandinsky's theory of painting and we outlined it. I don't know where Gedrius found them. The libretto may have been provided by Alfred Schnittke.

Anna Konstantinova $(\mathrm{PhD}$, theater critic and historian of theater, lecturer at the Academy of Dramatic Art, St. Petersburg) spoke at the conference on the Teatr plastičeskoj dramy in the Context of Problematics of the Synthesis of the Arts. As a group, we had seen a video of a reconstruction of Kandinsky's Pictures at an Exhibition, and I recently asked Anna how that had changed her sense of the work of Mackievičius on The Yellow Sound. 
THE YELLOW SOUND:

MACIKIEVIČIUS 'PRO AND CONTRA' KANDINSIKY

Anna Konstantinova

Kandinsky's theater experiments relate to the years 1908-1928 - a period when the practitioners and theorists in various fields of creativity were engaged in the problem of the synthesis of arts. At the same time, the director's theater experienced its formation. Therefore, we owe the birth of Kandinsky's stage compositions not only to his passion for music and to his controversy with the theory of Wagner. It can be said that it was prepared for by the whole course of development of the theater art with its magnificently developed spatial component, with its constant gravitation toward the compositional principles of the visual arts (whose theory and terminology were elaborated and fixed in more detail). The theater of Kandinsky discovered and mastered new tasks for itself: after a centuries-old dictatorship of the literary play, it won the right not to illustrate a verbal text, but to materialize its meanings, its own artistic ideas and even the definitions of "adjacent" areas of art (color, rhythm, etc.). The priority of the "stage text" over the literary one was announced by the performances of Max Reinhardt and Jacques Copeau, Vsevolod Meyerhold spoke about it ("the words in the theater are only patterns on the outline of the movements"), and later, Étienne Decroux called for it, too.

The authors of the performances, claiming new forms, had to re-solve the problem of drama: to create the text of the performance, free from literary fetters, revealing the nature of theater based on action. In the field of interpretation of the play, systems and methods were created, which our contemporaries still use actively and successfully. For Plastičeskij Theater, the problem of one's own drama is still relevant today (a hundred years after the creation of Kandinsky's stage compositions).

The search for a way to organize dramatically the text of a performance as a spatial art is the most important aspect, common to the creative work of Wassily Kandinsky and Giedrius Mackievičius.

In his stage compositions, Kandinsky tried to fashion verbal constructions that organize the visual attention of the spectator, wanting to unfold his forms and colors in time. When you get acquainted with his dramatic experiments (it seems to us incorrect, especially since the author himself avoided it, to call them "plays", as researchers sometimes do), you can grasp the highest degree of conventionality, which they inherited from pictorial sources. At first glance, the compositions are extremely "non-theatrical" (and their texts clearly not intended to be literally translated onto the stage). At 
the same time, too loose an interpretation threatens to lose the author's concept, which is recognizable with great difficulty in the text. The accentuated literary intonation, the fragments of poetic text, the abstract-symbolic characters, the absence of visible dramatic relations between them are emphasized - everything makes one doubt the presence of the task of any action and dramatic logic. It is not by chance that all the well-known performances of The Yellow Sound are radically unlike each other visually, rhythmically and stylistically (Krymskaya 2014). It is not by chance that Kandinsky did not consider it necessary to publish the absolute majority of his texts (with the exception of The Yellow Sound and a fragment of the The Violet Curtain). None of the compositions were put on the stage during Kandinsky's lifetime, either by himself or by his contemporaries; therefore, the mystery of his dramaturgical experiments seems forever insoluble.

The only precedent that comes to the aid of the researcher - the production of Pictures at an Exhibition, realized by the artist himself (to the music of the famous cycle of piano pieces by Modest Mussorgsky, Friedrich-Theater in Dessau, 1928) (Birr, Burde 2017). Thanks to the reconstruction of 1983 (University of Arts, Berlin), we can see this "non-figurative picture," where the most conditional personages-objects move, animated by means of theatrical mechanics and light. With jewel-like precision, invisible stanchions rise and fall, geometric shapes and colored spots appear, massive architectural motifs are replaced by linear outlines in perfect harmony with the background music... The drama of the performance successfully overcomes the structure it is mounted on. The "pictures" make up a convincingly holistic series of events, coming to a triumphal finale without a single word. No doubt: Kandinsky, during the periods of his work on the production, possessed a deep understanding of the active nature of the performing arts and mastered the exact techniques of its implementation. Technically, he could rely on the experience and legacy of theatrical predecessors - from Pietro Gonzaga and Andrei Roller, to Edward Gordon Craig and Adolph Appia. But of course, his successful experience in creating the drama on the basis of a visual text, where geometric characters, light and music became the protagonists, was certainly innovative for his time. We can say that this experience of creating "live animation" brings Kandinsky closer to the ideas of cinema. Stage sketches and the original explication, which Kandinsky himself made for the 1928 production, have survived. The drawings and notes detail the visual form, the partiture of light and the technical conditions of each episode of Pictures.... This suggests: the stage compositions were written by Kandinsky for development with detailed explanation, which was supposed to reveal his 
artistic ideas in the text of the performance. It is possible that the artist came to this device only during the period when he was creating the Pictures at an Exhibition, after unsuccessful attempts to embody other stage compositions. This is a subject for serious interdisciplinary research. In any case, today we have the right to rank Kandinsky as one of the founders of the dramaturgy of the modern Plastičeskij teatr.

Later, Kandinsky's legacy was reflected in the work of Mackievičius, who also addressed the problem of spatial problems in constructing a montage. Being here almost in the role of choreographer, Mackievičius created a Teatr plastičeskoj dramy for the already-completed music of Alfred Schnittke, written in 1974 (the composer was the initiator of the production of The Yellow Sound at the Teatr plastičeskoj dramy) (Mackevičiene 2010:35). It must be recalled: in the center of the pieces staged by Mackievičius most often stood a dramatically active hero, with a dramatically active fate or (at least) with a dramatically active inner life. In addition, the verbal text of the script appeared only after the completion of the improvisational rehearsal process, after the opening of the performance. But for the production of The Yellow Sound, the conditions of the musical composition of Schnittke's work were set, and thus preceded the etude work. At the same time, the Teatr plastičeskoj dramy of Mackievičius interpreted Kandinsky's stage composition very freely. The plot of the performance turned out to have much more in common with Kandinsky's theory of color, developed by the artist in his treatise On the Spiritual in Art, covering a wide range of not only aesthetic, but also general philosophical problems. Each color, according to Kandinsky, is a certain spiritual substance corresponding to certain eternal spheres of being (Mackevičienè 2010: 35). Therefore, in the play of Mackievičius, there were not charismatic heroes who acted, but allegorical characters represented as conventional shapes.

The production of the Teatr plastičeskoj dramy (together with the ensemble of soloists of the orchestra of the Bolshoi Theater of the USSR) opened on January 6, 1984. By its aesthetics and plastic solution, The Yellow Sound turned out to be very different from other performances of the Mackievičius Theater. The composition consisted of six parts: "Eternal", "Destruction", "Yellow Flower", "Nabat", "Slavery", "Scourge”. Multifaceted mises-en-scène are carefully organized, the artistic vocabulary is a "dehumanized" one. The avant-garde lines of the multi-colored costumes attracted attention (the actors changed them several times during the performance) and bright 'fantastic' make-up did, too. Mackievičius's cosmogonic story told the story of the birth in the chaotic darkness of the Eternal Light - Spark. The symbolic personage travels among the personified forces of evil, which are controlled by the conductor- 
Dictator, fights with them, is reborn in human souls. The plot is revealed through devices that are close to contemporary ballet, "visual" or "physical" theater (also resembling the motifs of the productions of Modris Tenisons and Henryk Tomaszewski).

Criticism noted that the play lacks dance lightness. Monotony, expressed in the repetition of the same elements, deprives the movement of energy, binds the dynamic development of the action. And yet we met with a stage creation, striking in its artistic courage and with a sharply modern sound (L'vov 1989: 5). About The Yellow Sound by Mackievičius-Schnittke almost nothing was written by eye witnesses. But the influence of this performance on the development of the language of the Soviet-Russian theater was surely important already in the 1980 s and 1990s.

\section{SELECTED REFERENCES}

Birr, Horst, Burde, Julia, "Bilder einer Ausstellung' / 'Pictures at an Exhibition' (Mussorgsky, Kandinsky) - The 1983 Stage Reconstruction," in Kandinsky and Theater-Performance. Dialogues with Contemporary Art, International Conference, Curator Nadia Podzemskaia (Moscow, State Institute for Art Studies), p. 14-15.

Decroux 1985: Decroux, Etienne, Words on mime (published by Mime Journal, Claremont, CA: Pomona College Theatre Department).

Konstantinova 2012: Konstantinova, Anna, Poisk novyx prinzipov sceničeskoj obraznosti. Plastičeskie spektakli v sovetskp-rossijskov prostranstve 1970-90-x godov (Search for new principles of stage imagery. Plastic performances in the Soviet-Russian theater space 1970-1990s.) (LAMBERT Academic Publishing).

Krymskaya 2014: Krymskaja, Ilona, “Istorija teatral'nyx voploščenij sceničeskoj kompozicii V. Kandinskogo "Želtyj zvuk”' (The history of theatrical incarnations of the stage composition of V. Kandinsky's 'The Yellow Sound'), in Vestnik Akademii Russkogo baleta imeni Agrippiny Vaganovoj, (n 3 [32]), pp. 152 - 166.

L'vov, V., "V mire plastiki, muzyki, sveta. V mire plastiki, muzyki, sveta..." (In the world of plastics, music, light), Myzykal'naja žizn' (n 14), p. 4 - 5.

Mackevičiene, Marina, "The name," in Mackevičius, Giedrius, Preodolenie (Overcoming) (Moscow, Ripol-Klassik), pp. 22 - 44. 


\title{
B. POETRY
}

\section{KANDINSKY'S THEATER OF THE WORD:}

FROM "SOUNDS" TO "VIOLET"

Boris Sokolov

\begin{abstract}
Kandinsky experimented in both literature and theatre, with word and sound and how they correlate. Read here about his volume of poetry, Sounds, his stage compositions, and how his thinking and efforts shifted over time.
\end{abstract}

Keywords: Kandinsky. Poetry. Stage

\section{RESUMO}

Kandinsky realizou experiências tanto na literatura, quanto no teatro, trabalhando com palavra e som e como eles se interrelacionam. Neste artigo, discorre-se sobre seu livro de poemas, Sonoridades, suas composições para o palco, e como suas intenções e motivações se transformaram com o tempo.

Palavras-chave: Kandinsky, Poesia, Teatro.

$\odot$

Kandinsky's experiments in literature and theater are closely related to his experiments in the realm of the word, sound, and their semantic correlations. The first series of works in this field is the series of woodcuts "Poems Without Words" (1903), where symbolic "Russian" motifs are presented as wordless poetry. From 1907 and 1908 onwards, Kandinsky wrote and reworked various texts for the stage several times: at first, fragments in the manner of Maeterlinck, then entire scores with choruses and solos, singing and "alogical" sounds. Later, Kandinsky noted that he was the first to introduce a set of abstract sounds to the stage - "Kalasimunofakola" in "The Yellow Sound".

Kandinsky's experiment with the theatrical qualities of the word can be discerned in greater detail in his poems, prose and theoretical writings. In the texts for the "Sounds" album (Russian version of 1910, German of 1912) one can find strange events that have a mysterious, esoteric meaning (the characters shouting in "Motley Meadow"), as well as the words divided into parts and reflecting the hero's feelings ("Gaze and Lightning"), and ecstatic 
rhythmic passages resembling shamanic incantations ("See", "Soft"). In the texts of the latter type, all the forms of utterance are brought together in a wave of emotional exultation: "Open wide the door! Or the fold will tear the roof right through"!

In his essay "On Stage Composition" $(1912,1918)$ Kandinsky shows that every object and phenomenon "is beaming forth its own inner sounding", and this sound "obtains a particular sonority at the moment that utward function diminishes". In the play "The Yellow Sound", symbolic and absurdist scenes create harsh contrasts, and Kandinsky uses choral singing and shouting. In the unfinished poetry cycle "Flowers without Odor" (1914) the artist uses folklore themes as a pretext for sound imitations ("And from every side stones are rolling. Grrrrrrrr...... khhhhhh"), glossolalia ("The sound of the fleeing was as an alarm bell. So - und o-f fle-eing. Fle - e - e - e - e - ing. Le - e - ing. I - i ing"), and for the sets of alliterations without any logical connection ("A freak struck with a narrow iron" - in Russian there are repeating "ou", "Ourod oudaril ouzkim outjugom").

The liberation of the word and its hidden sound continued in Kandinsky $s$ last stage work, "Violet curtain" or "Violet" (1914, 1926): "Ouff! So grandly sunk the wall! // Ouff! What a very lovely hole!"

1918 and 1926 saw a new phase in Kandinsky's experiments. The artist felt unable to develop symbolic forms any longer, and therefore called for the pursuit of strong, if rough, artistic means. He suggested that lessons should be learnt from acrobats and eccentric actors, because they had a key to "impartial", and therefore abstract, movement. He insisted that all the arts would be renewed in the "absorbing center" of the theater.

The search for "alogics" also influenced the play "Violet", where banal dialogues and mimed scenes have a large role. In 1926, Kandinsky replaced the messianic finale of the piece with a dialogue on the forms and colors of everyday things, which end with
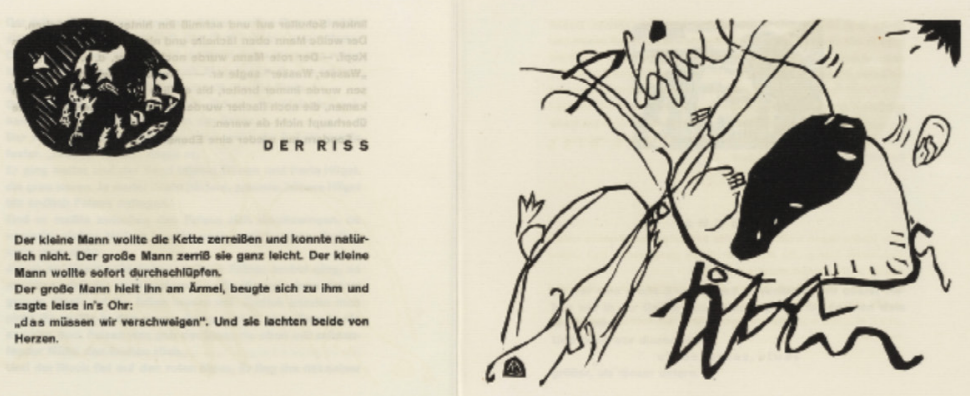

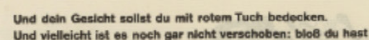

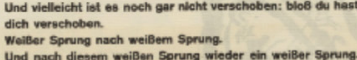

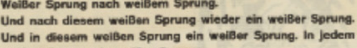

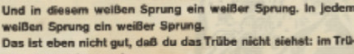
ben silter es ja gerrade.

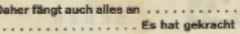

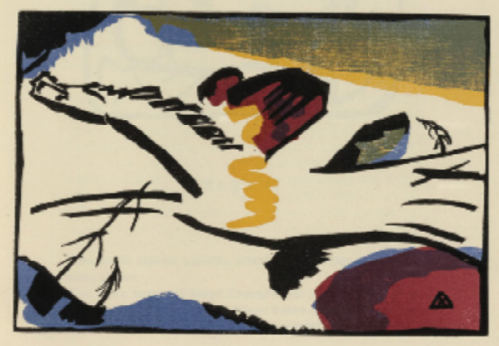


the words: "Green longing" (in Russian "a dreadful longing"). Kandinsky, however, was unable to find a form suitable for his new ideas, and could not find collaborators wishing to create "alogic" "synthetic compositions". In 1928 he staged an "abstract" ballet "Pictures at an Exhibition" for the stage, thus coming back to the "poems without words", more familiar to a painter. 


\title{
1. L'ABSTRACTION ET L'ATONALITÉ. L'AMITIÉ DE
}

KANDINSKY ET SCHOENBERG

Jelena Hahl-Fontaine

\begin{abstract}
The highly interesting correspondence between Kandinsky and his friend and "music-counterpart," the innovative composer Arnold Schoenberg, deals with all the arts and their synthesis in their stage plays - genuine inventions of modernism. These letters, written in German, have also been published in English, French, Russian and Japanese.
\end{abstract}

Keywords: Letters Kandinsky/Schoenberg.

\section{RESUMO}

A reveladora correspondência entre Kandinsky e seu amigo e contraparte musical, o inovador Arnold Schoenberg, lida com todas as artes e sua sintese em peças para o teatro - genuínas invenções do modernismo. Tais cartas, escritas em alemão, foram também publicadas em inglês, francês, russo e japonês.

Palavras-chave: Cartas Kandinsky/Schoenberg.

○

Note: Texte d'une conférence donnée à l'Université de Louvain-la-Neuve, le 8 février 2006; la présente publication n'est pas accompagnée des illustrations, qui sont aisément accessibles dans des catalogues raisonnés et d'autres ouvrages.

(...) C'est à propos de l'art abstrait que Kandinsky a dit: "Le contenu est plus important que la forme"! Mais quel est le contenu de l'art abstrait? Une réponse partielle mène à une autre question: Quel est le contenu de la musique? En écoutant des œuvres instrumentales... nous tracassons-nous sans cesse avec la question: "Qu'est-ce que cela represente?" — Non, évidemment non!

Et ce qui concerne la musique atonale de Schoenberg : jusqu'à quel point est-elle comparable à l'abstraction? La disparition de l'objet dans la peinture nous fait penser à la disparition du thème en musique. Et quand le fond du tableau ne se démarque plus par rapport à la forme, nous pensons aux voix 
secondaires qui perdent leur caractère d'accompagnement ... etc. etc. Il existe de nombreux parallèles, les uns superficiels, les autres fondamentaux.

Mais, la rupture avec la tradition est-elle aussi radicale chez Schoenberg que chez Kandinsky? (A mon avis, non, l'abstraction est un phénomène FONDAMENTALEMENT différent de l'art figuratif). - Après tout, Schoenberg admirait Gustav Mahler; et par son seul professeur de composition, Zemlinsky, il devait beaucoup à Wagner, ainsi qu'à Brahms. Pourtant, surprise, Schoenberg lui-même a dit que la plus grande influence lui est venue ... de Mozart!

(Mozart - omniprésent cette année - nous dirait sans doute: "Vous jouez toujours ma musique? Vous l'aimez plus que vos compositeurs contemporainsclassiques? A MON époque, on ne jouait que la musique contemporaine! Si vous n'arrivez pas à apprécier les innovations, vous ratez une telle BEAUTE, une telle richesse, une telle joie! Vous trouvez trop de dissonnances chez Boulez, Stockhausen ou Scelsi ? Mais la dissonance d'hier est l'harmonie d'aujourd'hui, — annonçait Kandinsky. Il s'agit dans les innovations surtout d'une plus grande liberté et (dans l'art visuel) d'une simplification, d'une réduction! Pourquoi est-ce moins accessible?" - Mozart a du mai à compendre, et il se retire chez lui.)

Notre problème est réel. Le décalage entre la création et l'appréciation du public n'a jamais été aussi grand qu'aujoud'hui ! Kandinsky a prédit deux générations, il était encore trop optimiste. Maintenant, avec un recul de près d'un siècle, nous pouvons mieux juger ce qui est de qualité et qui a gardé son influence - de toutes les innovations du début du XXe siècle.

Quelle chance d'avoir Schoenberg et Kandinsky, ces grands fondateurscréateurs comme guides vers notre époque. Nous pouvons suivre leur progression logique, sérieuse, pas trop rapide, pas aléatoire - pour continuer par leurs élèves jusqu'a notre époque. Ils ont créé un fondement solide et honnête dans les années dix: une période passionnante, anarchique, débordante de créativité! ("L'Avant-garde russe ", l'exposition à Bruxelles en 2006, n'est pas pensable sans Kandinsky, qui a aidé ses collègues russes à exposer, il les a publiés, ils entretenaient ensemble des liens étroits...).

Quelques remarques BIOGRAPHIQUES.

Schoenberg est né à Vienne en 1874 dans une famille juive, modeste. Il avait 16 ans quand son père est mort; il a été obligé de faire un stage dans une banque et de gagner sa vie...

Kandinsky, Russe avec une grand-mère balte, est né à Moscou en 1866. Sa famille appartenait à l'intelligentsia, on parlait naturellement le français, on voyageait en France, en Italie...

Un point commun: tous les deux avaient un père très progressiste (Le père de Kandinsky, avec qui il vivait depuis le divorce de ses parents, a visité Herzen 
à Londres, ses ancêtres étaient proches des Décabristes). L'oncle de Schoenberg, qui était responsable de son éducation après la mort du père, était encore plus progressiste, quasi anarchiste... (Le mot "anarchie", dans son sens original, était un terme très positif, surtout en Russie. Dans leurs écrits Schoenberg, et encore plus Kandinsky, utilisent très souvent le mot "Anarchie", dans le sens de liberté totale, indispensable en art).

Un autre point commun se trouve dans leurs activités politiques et sociales de jeunesse. Le fait est peu connu, parce que tous deux ont insisté plus tard que la politique ne joue aucune rôle (Schoenberg "n'avait pas le temps", et Kandinsky après trois émigrations en avait assez!). C'était devenu vrai. Mais dans leur jeunesse, tous deux ont été activement préoccupés de JUSTICE, d'EQUITE, et de droits des ouvriers (Kandinsky s'est aussi à plusieurs occasions prononcé pour les droits des femmes). - Schoenberg, toujours rebelle, moqueur et protestataire, faisait partie de groupes qui discutaient beaucoup...

Kandinsky était un scientifique jusqu'à l'âge de trente ans, comme sociologue et juriste et, pendant un an, assistant d'un économiste à l'Université de Moscou. Il a écrit une thèse sur le "Salaire minimum des ouvriers", qui n'a été redécouverte qu'en 2005... Ce n'est que récemment que l'on a retrouvé à Moscou encore d'autres manuscrits et publications de nature scientifique du jeune juriste, économiste et ethnographe.

Ces engagements idéalistes de jeunesse revèlent un sens aigu de l'éthique. C'est important pour évaluer plus tard leur RIGUEUR artistique et leur élan quasi missionnaire, sans compromis, suivant leur "nécessité intérieure" (un terme-clé de Kandinsky, mais que l'on rencontre également chez Schoenberg).

Un troisième point commun: Tous les deux étaient presque AUTODIDACTES! Leurs études artistiques ont été de courte durée et pas très académiques. D'ailleurs Kandinsky a dit tout à fait sérieusement: "Combien de jeunes talents ont été gâchés par l'académie!"

Heureusement pour nous, ces deux génies se sont rencontrés. Le 2 janvier 1911, Kandinsky assista à Munich à un concert en compagnie de son jeune collègue Franz Marc et de sa femme Maria, une musicienne accomplie (et d'autres membres de ce cercle d'artistes russo-allemands). On jouait le Quatuor à cordes op. 10 et les Trois Morceaux pour piano op. 11 de Schoenberg, où commence l'éviction de la tonalité. Kandinsky, l'amateur-dilettante (saufqu'il jouait du piano et du violoncelle, - et naturellement doué d'une sensibilité extraordinaire) était l'un des premiers à vraiment apprécier la musique novatrice. Il fut tellement ravi de la musique de Schoenberg qu'il peignit son lmpression III

(Concert), un chef d'oeuvre dynamique et simple, qui à première vue semble 
déjà non-figuratif. Mais deux petits dessins nous aident à identifier la tache noire comme un piano, et des taches bigarrées et très sommaires comme des auditeurs. Mais le grand plan d'un jaune vif à droite ne signifie plus rien (sinon la joie pure), il est détaché de l'objet et du "contenu".

Kandinsky écrit au compositeur le 18 janvier 1911 dans sa première lettre: “... Nos aspirations et notre façon de penser et de sentir ont tant en commun. ... Vous avez réalisé dans vos oeuvres ce dont j'avais un si grand désir : Le cheminement autonome, la vie propre des voix individuelles... sont justement ce que moi aussi je recherche sous une forme picturale." - Après l'échange de quelques lettres, il ajoute le 9 avril 1911: “...Je vous envie. Les musiciens ont vraiment de la chance, de pratiquer un art, un vrai art, qui renonce à toute fonction pratique. Combien de temps la peinture devra-t-elle attendre ce moment?... La couleur, la ligne en soi et pour soi - quelle force et quelle beauté illimitées possèdent ces moyens picturaux!" Le peintre admirait la musique comme l'art le plus "abstrait" et voulait copier le PRINCIPE de la musique, mais jamais "peindre la musique ni mes états d'âme."

Franz Marc, lui aussi, fut fortement impressionné par le même concert. Dans une lettre à August Macke, un autre membre du groupe munichois, il raconte le 14 janvier 1911: "Peux-tu imaginer une musique où la tonalité (donc le maintien d'un ton) est totalement abolie? J'ai pensé sans cesse aux grandes compositions de Kandinsky, qui n'admettait pas non plus la moindre trace de tonalité... et aussi, à ses taches volantes à l'écoute de cette musique où chaque son joué existe pour soi (une sorte de toile blanche entre les taches de couleur). Schoenberg part du principe que les concepts de consonnance et de dissonnance n'existent pas. Une soi-disant dissonance n'est qu'une consonnance plus éloignée. Je me suis longuement entretenu de Schoenberg avec Kandinsky et j'ai lui ai soumis la conséquence qu'a tirée Maira (son épouse musicienne): elle prétend qu'il travaille avec des mélanges d'accords qui ne se résolvent absolument pas, sans aucun timbre, UNIQUEMENT DE L'EXPRESSION, des gestes. Kandinsky en était enthousiasmé: c'est son but aussi: son "beau coloris", la dissolution de ses couleurs dans une GRANDE harmonie, un Faute de mieux dans son oeuvre, dont il devrait encore se consoler; (que Rouault, Braque, Picasso auraient déjà compris ce principe schoenbergien, disait Kandinsky) "J'ai aussi vu les dernières choses de Kandinsky dans son atelier et j'avoue avoir rarement ressenti une aussi profonde et lugubre impression face à des tableaux: Kandinsky fouille plus profond que tous."

Retour à SCHOENBERG. Il a reçu la lettre de Kandinsky, un inconnu, qui lui a envoyé quelques gravures et photos. Il répond immédiatement par une très longue lettre: "Les gravures m'ont énormément plu... C'est une très grande joie 
pour moi que ce soit un artiste pratiquant un art différent qui trouve des correspondances avec moi." Il est d'accord que l'intuition est plus importante que les qualités acquises; “On devait s'exprimer directement!” Lui aussi déteste le matérialisme. - Et comme on peut le découvrir dans leurs premières oeuvres théoriques, qu'ils écrivirent en même temps, Kandinsky le livre mince (mais qui l'a rendu plus célèbre que ses expositions) Sur le Spirituel dans l'art - et Schoenberg son volume important Traité de l'harmonie, - il y avait encore beaucoup plus de points en commun. Kandinsky a d'ailleurs repris d'une préédition du "Traité..." quelques paragraphes pour les traduire et les commenter dans le catalogue d'une exposition importante organisée en Russie, le "Salon II" de 1911.

Schoenberg avoue que lui aussi il peint (en fait, il a eu déjà sa première exposition à Vienne en octobre 1910, ce qui a donné à un critique l'occasion de commenter: "C'est pour perdre à la fois l'ouïe et la vue." ... Kandinsky ne partageait pas du tout cet avis. Il a inclus des tableaux de Schoenberg dans la première exposition et dans l'almanach "Le Cavalier Bleu". "L'autoportrait de dos", naif, simple, mais quelle solution spatiale surprenante avec le chemin qui monte au ciel! Et une des nombreuses "Visions" (ou "Regards"), fort expressive, les yeux bordés de rouge. Schoenberg, qui a peint plusieurs grands portraits et environ 70 autoportraits, a dit que c'est le regard qui l'intéresse (Comme examples le "Regard bleu", "Des larmes", la "Vision de Chries", où le visage forme un tout avec le fond). - Quasi toute son oeuvre, très originale, expressive, authentique, naïve, est figurative. Pourtant, il précise son admiration pour les gravures de Kandinsky : "Avant tout le fait qui vous soyez très peu figuratif. Je ne crois pas non plus que la peinture doive absolutment être figurative. Je pense même exactement le contraire." Cela veut probablement dire que Schoenberg, lui aussi, aspirait à arriver à un art moins figuratif.

Kandinsky, qui aimait aussi beaucoup le peintre naif Henri Rousseau (parce qu'il est son "antipode", comme il a expliqué), a écrit un article sur la peinture de son nouvel ami: "Dans chaque tableau de Schoenberg, le désir intérieur de l'artiste parle dans la forme qui lui correspond. De même que dans sa musique... Schoenberg renonce au superflu et va droit à l'essentiel. Il néglige tout "enjolivement", "toute belle peinture." 4) Cette caractéristique s'applique évidemment aussi à son propre art: la fameuse "nécessité intérieure"... Dans sa troisième lettre, le 6 février 1911, Kandinsky avoue: "Je suis vraiment enthousiasmé par vos peintures... Je pressens que notre grande époque n'apportera pas qu'une mais de nombreuses possibilités: l'abstraction totale et le réalisme à l'état pur. Je tends, pour ma part, de plus en plus vers la première. La seconde est néanmoins également la bienvenue... C'est précisement le réel que je ressens si fortement dans vos peintures. Ce réalisme ne ressemble naturellement en aucune façon à celui que 
nous avons désormais dépassé. Je pense de nouveau à vos octaves parallèles "interdites"... Cette tendance humaine à la pétrification de la forme est effrayante. Hier, on anéantissait ceux qui produisaient cette nouvelle forme. Aujourd'hui cette forme est une loi à jamais inébranlable... Cela montre combien les hommes tiennent avant tout aux apparences... Parfois, ma patience est à bout!"

Kandinsky avait pour chaque expression d'une authenticité artistique une perspicacité particulièrement fine. Il décela sans doute dans les tableaux figuratifs de Schoenberg cette droiture et cette force que nous ne sommes peut-être plus capables de reconnaître. Le recours aux formes primitives dans le développement musical de Schoenberg correspond au même phénomène dans ses tableaux, — comme le constate Paris von Gütersloh en 1912: "..il tente de redonner enfin à la peinture cet état de primitivité psychique, cette sorte de vie antérieure préhistorique (...) et lui seul pouvait créer ces formes, tout à fait futiles pour le connaisseur, lui qui semble immunisé, protégé par un art déjà compris et en avance, sa musique; ..."

Schoenberg a (un peu) appris la technique de peinture à l'huile de Richard Gerstl un grand innovateur expressioniste/fauve. Gerstl habitait dans la même maison que Schoenberg. En 1908, Mathilde Schoenberg quittait sa famille pour vivre avec Gerstl, mais elle est bientôt rentrée et la famille (avec leurs deux enfants) était sauvée. Quelques mois plus tard, Gerstl s'est suicidé - à 25 ans! Schoenberg lui aussi se sentait proche du suicide... Au lieu de chercher de l'aide chez Sigmund Freud, (un autre grand innovateur de son temps, qui inventait au même moment à Vienne la psychanalyse), Schoenberg a discuté de son malheur dans ses œuvres. Il travaillait comme un fou: en 17 jours, il a composé son monodrame "Erwartung", introduisant le "Sprechgesang", un "parlando chanté". Il est intéressant qu'à cette époque encore, dans certains cercles littéraires (par exemple Stefan George, dont Schoenberg a plusieurs fois utilisé les textes), des poèmes étaient déclamés presque en chantant... A propos d' "Erwartung", l'élève de Schoenberg, Anton Webern, a dit: "Il n'existe pas une mesure qui ne soit une nouvelle combination de couleurs."

Schoenberg compose aussi "Le feuillage du coeur" et "Pelléas et Mélisande", sur des textes de Maurice Maeterlinck, qui a aussi joué un grand rôle pour Kandinsky. Avec sa méthode de dépersonnalisation des personnages (pour les rendre en allégories, en archétypes), Maeterlinck a été le précurseur du renouvellement du théâtre russe...

Kandinsky a appris de Maeterlinck que la répetition d'un mot ou la séparation d'une lettre, d'un signe quelconque (une virgule par exemple) de sa signification langagière pouvait conduire à sa "forme pure", à sa "sonorité pure". Là aussi, il y a une des sources possibles de l'abstraction... 
Le profond intérêt de Kandinsky pour une synthèse des arts et sa plus haute productivité littéraire coïncident il ne faut pas y voir un hasard - avec la période-charnière où il délaisse l'art figuratif. Ses lettres à Schoenberg nous le révèlent: il vient de traverser une époque qui lui a paru interminable de quête et d'errance (il ressentait le désir de "se mordre le coude" d'impatience...). Comme ce fut aussi le cas pour Schoenberg avant d'arriver à l'atonalité, la tension accumulée dans une phase de remise en cause de leur art trouve un soulagement dans le recours à un autre mode d'expression. Schoenberg commence à peindre, et les deux tiers de ses tableaux ont été créés entre 1908 et 1912. Au même moment, Kandinsky écrit ses poèmes en prose, les "Sonorités", dont les dernières de 1912 sont déjà "pré-dadaistes a-logiques comme les poèmes "zaum /transrationales" des cubo-futuristes russes. Quatre ans plus tard, les "Sonorités" étaient saluées avec enthousiasme et récitées au Cabaret Voltaire à Zürich par les Dadaistes Hugo Ball, Tristan Tzara et d'autres.

Le thème principal de la correspondence entre Kandinsky et Schoenberg était LE THEATRE! Allégés de toute science professionnelle, dans le rôle plus libre de "dilettantes", ils surent produire des oeuvres dont la radicalité et la modernité dépassent de loin. Ce que le théâtre officiel était alors en mesure de produire. Ils aspirent à une synthèse des arts, au "spectacle total", cette utopie du romantisme qui hanta Richard Wagner.

Schoenberg écrit lui-même le texte de sa composition scénique La Main Heureuse. La partie la plus intéressante:" Parallèlement au crescendo de vent se produit un crescendo de lumière. Il commence avec une lumière sourde rouge, qui devient marron, puis verdâtre... Elle se change en un gris-bleu, suivi d'un violet... un rouge de plus en plus brilliant... puis en jaune vif." "Une intention symboliste/psychologisante demeure: "Pendant ce crescendo de lumière et de tempête, l'Homme se comporte comme si les deux phénomènes émanaient de lui... ses yeux s'enflamment (lumière verdâtre), Quand la lumière jaune apparaît, sa tête semble près d'éclater."

Kandinsky, lui aussi, avait commencé à la manière symboliste proche de Maeterlinck un conte d'après Andersen et "Daphnis et Chloe" (qu'il a lui-même traduit du grec en russe, malgré une traduction existante de 1903 par Merezhkovskij). Les ravisseurs de Chloe deviennent "Les Géants" (des géants jaunes figurent sur un tableau de 1909 finalement, après plusieurs manuscrits en russe et en allemand, où chaque version devient plus abstraite. Kandinsky arrive à la Sonorité jaune, qu'il publie en 1912 dans son célèbre almanach "Le Cavalier bleu".

Depuis 1909 c'était avec son plus proche ami (le seul qu'il tutoyait), le compositeur russe Thomas de Hartmann, de 20 ans plus jeune), que Kandinsky 
faisait des expériences de 'spectacle total'. Hartmann se souvient, dans le manuscrit inédit" L'indéchiffrable Kandinsky":

"Cette période fut marquée pour lui par un intérêt toujours croissant pour la musique et par une insatisfaction envers le théâtre actuel. La façon dont Wagner avait donné corps aux trois formes d'art ne constituait — à son avis — qu'un premier balbutiement. Lui-même donnait alors dans ses compositions pour la scène (qui probablement ne seront représentées que dans l'avenir) le résultat de ses idées."

Hartmann ne se trompait pas : c'est en 1975 seulement que la première de "Sonorité jaune" put avoir lieu (à Beaume et à Paris, au Théâtre du Châtelet malheureusement pas adéquate). Pourtant, c'est jouable. C'est un libre jeu de toutes les formes d'expression, les personnages en sont réduits à animer les couleurs qu'ils revêtent, et il n'y a pas, à proprement parler, d'action. Pour l'essentiel, il s'agit d'un jeu (indépendant) de couleurs, de mouvements, de sons et de lumière. La LANGUE est réduite à un seul cri: "des mots incompréhensibles avec une prédominance du son A." La voix humaine n'est plus obscurcie par le sens de la parole! On remarque une sensibilité pour le silence: l'auteur indique exactement la durée des pauses en secondes et minutes. (Dans les années vingt, Kandinsky suggéra que la musique s'intéresse plus au silence et à l'intégrer activement, - ce qui se fait de plus en plus de nos jours).

Dans ses "compositions pour la scène", le chemin de Kandinsky vers l'abstraction se révèle parallèle à son évolution picturale, surtout la "Sonorité jaune" est plus progressiste, à cet égard, que "La Main heureuse" de Schoenberg, qui l'avoue lui-même: "La Sonorité jaune me plaît énormement. C'est exactement ce que j'ai cherché à réaliser dans ma "Main Heureuse". Mais vous allez plus loin que moi dans le renoncement à toute pensée consciente, à toute action conventionelle. C'est évidemment une grande qualité, un avantage... Nous sommes entourés d'énigmes... nous devons les affronter sans chercher des solutions... Les mystères sont un reflet de l'Inconcevable. A travers eux, nous apprenons à tenir l'Inconcevable pour possible, et nous nous approchons de Dieu, parce que nous n'exigeons plus de le comprendre, ... le mesurer, le critiquer, le nier. - Mais pour moi, votre "Sonorité jaune" n'est pas 'construction' (comme vous dites), mais une vision intérieure".

Kandinsky répond: "Il faut montrer les possibilités de la construction/ composition... La nécessité intérieure n'est qu'un thermomètre qui cependant conduit à la plus grande liberté. Par construction, on comprenait jusqu'à présent une géométrie insistante (Hodler, les cubistes).” D'ailleurs Kandinsky est le seul peintre innovatif qui n'a pas été influencé par le cubisme! "Ce que 
je veux montrer c'est que la construction peut aussi être atteinte par le principe de dissonnance, qu'elle a là bien plus de possibilités ... La Sonorité Jaune est construite comme mes tableaux. C'est ce qu'on appelle anarchie qui est une absence de toute loi... Un ordre a ses racines dans la Nécessité Intérieure... En bref: il existe une loi à des milliers de kilomètres de nous, à laquelle nous aspirons..., que nous pressentons... croyons même voir et à laquelle nous donnons, à cause de cela, diverses apparences. Ainsi l'évolution de Dieu, de la religion, de la science, de l'art. Et toutes ces apparences sont justes, puisqu'elles ont toutes été vues. Seulement, elles sont fausses car elles sont vues sous un seul angle. Et l'évolution ne consiste en somme qu'à tout faire apparaittre dans sa multiplicité, sa complexité. Et de plus en plus. C'est aussi le cas par exemple pour l'histoire de la musique: à une seule voix, mélodie, etc. — Et derrière cette dernière loi, il y en a, beaucoup plus loin, une autre; car elle-même ne représente qu'un seul aspect. Il y a de quoi devenir fou et chanter Hosanna."

Kandinsky et Schoenberg sont au-delà de toute catégorie de "dilettantes"; ils donnent au théâtre expressioniste allemand son impulsion la plus significative et par leurs oeuvres scéniques, ils ouvrent - Kandinsky plus radicalement que Schoenberg - de nouvelles possibilités créatrices. 


\title{
2. RUSSIAN PORTFOLIO:
}

THREE ON KANDINSKY AND MUSIC

KANDINSKY AND THE LANGUAGE OF MUSIC

Nadia Podzemskaia

THE MUSIC OF KANDINSKY'S THEATRE EXPERIMENTS

Nina Sviridovskaya

THE COLOR MUSIC OF ALEKSANDRA UNKOVSKAYA

Elena Scherbakova

\begin{abstract}
Kandinsky's theory of painting has often been difficult for visual artists but aroused lively responses in musical circles - especially in Russia, where Kandinsky established creative dialogues with musicians Thomas de Hartmann, Aleksandra Unkovskaya, Boleslav Yavorsky, Aleksandr Shenshin.
\end{abstract}

Keywords: Music. Painting. Language.

\section{RESUMO}

A Teoria da Pintura de Kandinsky é muitas vezes de difícil compreensão para artistas visuais, mas suscitou animadas respostas nos círculos musicais, especialmente na Rússia, onde Kandinsky estabeleu criativos diálogos com os músicos musicians Thomas de Hartmann, Aleksandra Unkovskaya, Boleslav Yavorsky, Aleksandr Shenshin.

Palavras-chave: Música. Pintura. Linguagem.

○

\subsection{RANDINSIKY AND THE LANGUAGE OF MUSIC Nadia Podzemskaia}

In January of 1911, Kandinsky, with his friends from the Munich New Artist's Association (Neue Künstlervereinigung München, NKVM), attended a Schönberg concert in Munich. Everyone noted the kinship between the music of one and the painting of the other. An intense correspondence between Kandinsky and Schönberg followed. The painter and the composer met each 
other in person in September of that year. The dialogue with Schönberg confirmed for Kandinsky his ideas about construction based on alogic or the principle of anarchy, which he was developing at the time. The latest additions to the first German version of his treatise On the Spiritual in Art, at the end of 1911, bears witness to this. Thus, the acquaintance with Schönberg came just at the moment Kandinsky was finalizing his theory of painting.

In fact, the history of On the Spiritual in Art shows: at all stages of his work on this treatise - in both German and Russian, between 1909 and 1921 — even while Kandinsky's theory of painting was receiving mixed responses from painters, it always aroused lively interest in musical circles.

Kandinsky had difficulty finding a publisher in Germany for his russified German-language text. Even in Russia his writing style was warmly criticized, and the aborted collaboration with the Futurists on the pamphlet A Slap in the Face of Public Taste in 1912 foreshadowed his complicated relationship with the avant-garde. Between 1919 and 1921, Kandinsky's writings struck readers as anachronistic, grounded in Symbolism. In fact, in Russia's artistic life after the revolution, even though he held positions of the highest rank, he was still seen as "foreign." In 1920, for example, to the surprise and indignation of more "radical" artists, he preferred to form relationships with more "moderate" artists, such as Falk, or with younger art historians and musicians who appreciated his ideas.

Among the latter was Evsei Shor (1891-1974). Kandinsky had met Evsei in Moscow in July 1913. He was the son of the pianist David Shor, founder of the famous "Trio of Moscow," an important personality in the diffusion of musical culture in Russia. Evsei was the academic secretary and lecturer at his father's "Studio Beethoven." Before The Great War, he founded, with Grigorij Angert, the Iskusstvo (Art) publishing house, whose mission was to make known in Russia new ideas in the different arts, to present them to Russian readers from the perspective of their relationships and links with classical art. These young Moscow publishers were oriented towards German culture and wished to publish On the Spiritual in Art in Russian. In his 1913 letters from Moscow to Munich, Kandinsky told Münter with great enthusiasm about his new publishers: "Angert is my publisher. Very nice, as he is different from [his German publisher] Piper!! A cultured musician, he does not want his publishing house to take care of the business end, only the ideas." The artist immediately reached so great an understanding with his young publishers that following the signing of the publishing contract for On the Spiritual in Art in Russian, he launched with Iskusstvo several other projects. All these projects were blocked and finally destroyed by the outbreak of the war and the events that followed. 
After the war forced Kandinsky to return from Germany to Russia, he continued his friendship with Evsei Shor, and with a whole circle of art historians and musicians who took part in a project on the science of art, which occupied the painter in 1919-1921. Their collaboration in Moscow, in particular in the framework of the Institute of Artistic Culture and later of the Russian Academy of Artistic Sciences, is still a little-known but important page which sheds new light on the Russian years of Kandinsky.

It is meaningful that Kandinsky found "his editors" in the Russian music world. He was introduced to it by a young composer Thomas de Hartmann (1885-1956) whom he had known in Munich since the end of 1908, and with whom he immediately became very close. It is with Hartmann that Kandinsky had put in place the experiments with different combinations of musical sound, pictorial color and dance movement (the last thanks to Aleksandr Sakharov, dancer with a background in painting, who joined them). From these experiments, begun in the winter-spring of 1909, came the stage compositions - the innovative plays for the theater. None of these were performed during Kandinsky's lifetime - although in a June 24, 1912 letter to Hartmann, held in the Russian State Archive for Literature and Art, Kandinsky said he hoped to "catch" Meyerhold for The Yellow Sound. But produced or not, these experiments were of crucial importance for the development of Kandinsky's painting and the theory that accompanied it from 1909-1910 on. The "liberation" of color was the result of a whole process at the heart of which was the need to systematically compare painting with music, studying the essence of color in relation to sound, and its effect on the listener.

It is indeed thanks to his creative dialogue with Hartmann, during their work on the stage compositions, that Kandinsky was able to transpose his theoretical thinking on The Language of Colors (Farbensprache) into On the Spiritual in Art (Über das Geistige in der Kunst) in the summer of 1909.

Also in 1909, Kandinsky became acquainted with a presentation made to the Theosophical Congress in Budapest by Aleksandra Unkovskaya, who talked about her method of teaching music to children using color. Kandinsky immediately saw in this method proof of the kinship between sound and color. Unkovskaya's writings can be found in Münter's archive in Munich. He hoped to go to Kaluga to meet the musicologist, and at the same time in Moscow to make the acquaintance of Skriabin, whose music he had heard with Hartmann and his wife Olga. At the time, Skriabin's "Prometheus" was only known through a few private concerts, and immediately became the subject of lively discussions in Moscow. As a result, in the 1910 version of On the Spiritual in Art, in a note on synaesthesia, he referred to Unkovskaya's method, and in 
the 1911 version, he added a reference to Leonid Sabaneev's recent article on Skriabin's "Prometheus."

In 1910, Hartmann introduced Kandinsky to musician and theorist Boleslav Yavorsky (1877-1942). "The best disciple of Taneyev, the most left-wing revolutionary in composition," Kandinsky wrote to Münter. It would be hard to imagine a more complimentary way to describe him: Hartmann had studied counterpoint with Sergei Taneyev while Taneyev was finishing his famous book Convertible Counterpoint in the Strict Style (pub. 1909), and initiated Kandinsky into these theories. Kandinsky soon learned more when he and Yavorsky met, and Yavorsky organized a conference where the ideas in On the Spiritual in Art were, for the first time, publicly presented by the artist and discussed in a close circle of musicians. Among them were Nadezhda Briusova, Evgenii Bogoslovsky and of course Yavorsky. Kandinsky wrote to Münter that he had read his text for two hours, with two breaks, in front of a "particularly attentive" audience that included Yavorsky and his disciple Briusova (sister of the poet Valeri Briusov); he had had a very interesting discussion with both of them.

Under the influence of all these musical impressions, as well as of his meeting with Schönberg, Kandinsky proposed to Franz Marc that they integrate into The Blue Rider Almanac a large section devoted to music. Originally, it was to have contained an article by Hartmann on Yavorsky, as well as a text by Unkovskaya and one by Briusova. This plan was modified; in the final publication, Russian music was covered by Hartmann's article "Anarchy in Music" and Sabaneev's article on Skriabin's "Pometheus," the latter translated into German by Kandinsky with the help of Hartmann and reviewed by Schönberg.

Kandinsky wrote to Münter that Yavorsky's musical theory was a "true sister" of his own theory of painting, a "direct construction based on the feeling and on physical and psychic action." In his 1910 article "Content and Form," for the first time Kandinsky developed his idea about a work of art as the center of a reciprocal relationship between artist and spectator: "The vibration of the soul of the artist must find a material form, a means of expression, which is capable of being picked up by the receiver." This relationship between the artist, the work of art and the viewer was presented as a chain: "Emotion — sensation — the work of art - sensation - emotion." This formula was based on the principle of the resonance of string instruments. It was a topos on which the Humboldtian interpretation of the mechanism of understanding between the speaker and the recipient of the utterance was based. In On the Spiritual in Art, he wrote that one must let the viewer "experience for himself the inner life of the picture, to let the picture affect the spectator directly"-that is, Kandinsky came to think of the work of art as a conversation: "If we carry on an interesting 
conversation with someone, we attempt to penetrate the depths of his soul; we seek an inner form, his thoughts and feelings. We do not worry about the fact that he employs words, which consist of letters, etc."

Kandinsky's approach to painting as a specific language must have found understanding in Yavorsky. At the time, he had already published his notes on the Construction of the Language of Music, in which he considered the languages of the visual arts and and music to be the two main and related expressions of life. Rooted in Bergson's philosophy, Yavorsky's approach founded a comparative study of music and the visual arts. Not only did Yavorsky leave a number of writings on painting (which remain unpublished), but he was also able to initiate his students into this kind of comparative exercise. Two of his followers at the time of the Great War, the historian and composer Aleksandr Shenshin and the historian and art theorist Aleksandr Gabritchevsky, were particularly close to Kandinsky in Moscow in 1920-1921. The sensitivity towards comparisons of the visual arts with music, refined in Yavorsky's classes, allowed them to launch, with Kandinsky, comparative works in the framework of a new science of art.

Shensin's research on the synthesis of the arts particularly impressed Kandinsky. In December of 1920, in a report on the activities of the Institute of Artistic Culture held in Moscow, he spoke of it in these terms:

"Experiments carried out have shown that art can be divided up into parts corresponding to certain mathematical relationships. The important work done in this direction by the composer Shenshin has demonstrated the possibility of translating from one artistic language into another. He took a Michelangelo tomb and a musical composition by Liszt on the same theme. Dividing the musical composition into its constituent parts, Shenshin obtained a certain correlation between the [numbers of] bars, which he translated into graphic form corresponding to the mechanical form that laid the basis of the work of Michelangelo."

This comparative study - which Shenshin presented in 1916 to Yavorsky, and then between 1920 and 1930 at several conferences - interested Kandinsky, who had dreamed for a long time of an opportunity to translate the languages of the various arts one into the other. In a letter to Jean Arp in 1912, he wrote that a complete understanding of a work of art was possible only for an artist capable of transposing the inner content of that work into an outer form of another art: "So you can play a picture, compose a piece of music as one composes poems, chisel a poem, dance a sculpture, paint a dance, etc. in all combinations." 
In the words of Yavorsky and Bergson, Shenshin defended the same idea as Kandinsky's in several texts in the first years after the revolution - texts now held in the Russian State Archive for Literature and Art - that is, that the creative moment is an organic process, the work of art is a result of the artist's life and an expression of the fullness of his nature. In the inner world, time-duration and space are indivisible, and division occurs during materialization. But if the creative moment is preserved intact, the material forms will obey the same rhythm. So the same mathematical law can be found, and the arts can be translated into one another. In this reasoning, Senshin is very close to the theses defended by Yavorsky in a conference held in 1913 at the Beethoven Studio where, according to Bergson, he spoke of time-duration as indivisible inner infinity, and defined rhythm as a relation of temporal parts between them and to the totality. Once outside, time can be divided by hearing or by sight - musical and visual expression are then analogous.

At the Institute of Artistic Culture in 1920, Kandinsky participated in experiments on the comparison of music and visual arts with Shenshin, Briusova and a young dancer and composer Evgenii Pavlov. With Pavlov, he tried to build an experimental working group on dance and movement, paying attention not only to form/drawing, but also to color in motion. Experiments with movement, in a broader sense, were organized in parallel by the art historian Aleksei Sidorov. Kandinsky also took part in those. One can find a direct connection between these experiments and Kandinsky's pioneering work a few years later in Dessau on the Pictures at an Exhibition. In 1928, when the artist was able to respond very quickly to the invitation to stage the music of Mussorgsky, his readiness was in great part because the very notion of such a spectacle where shapes, color and the light were put into movement, dreamed of by him long before, had been elaborated on and given a solid theoretical basis in 19201921, in collaboration with young Russian musicians and art historians.

This outline shows the extraordinary richness of the relationship between Kandinsky's art and theory and Russian musicians. Little known today, this new and stimulating perspective requires transverse research by an international collective. We are publishing here some fragments of this research in progress.

\section{SELECTED REFERENCES}

Kandinsky, Wassily, Complete Writings on Art, ed. by Kenneth C. Lindsay and Peter Vergo (New York : Da Capo, 1994).

Kandinsky, Wassily, Gesammelte Schriften 1889-1916. Farbensprache, Kompositionslehre und andere unveröffentlichte Texte, hrsg. von Helmut Friedel (München:

Prestel, 2007). 
Podzemskaia, Nadia, "Du Spirituel dans l'art: le projet d'édition russe de 1914 et l'écriture théorique de Kandinsky," in Genesis ( $\left.n^{\circ} 15,2000\right)$ pp. 43-65.

Podzemskaia, Nadia, “Živopisnyj kontrapunkt V.V. Kandinskogo, ili ob abstraktnov v iskusstve" (Kandinsky's "Counterpoint in Painting, or on the Abstract in Art," in Bespredmetnost' i Abstrakcija, ed. Georgij Kovalenko (Moscow : Nauka, 2011), pp. 113-156.

Yavorsky, Boleslav, Stroenie muzykal'noj reči: Materialy i zametki (Construction of the Language of Music: Materials and Notes), Part I (Moscow : typografy of G. Aralov, 1908).

○

\subsection{THE MUSIC OF KANDINSIKY'S THEATRE EXPERIMENTS}

Nina Sviridovskaya

PhD, Senior Assistant Professor, Moscow State Tchaikovsky Conservatory, Department of History of Russian Music

Several things make the topic of music in Kandinsky's theatre not an easy one. Firstly, not a single project was performed during his lifetime or saw the light of day; hence so many blueprints and drafts. Secondly, despite his deep thinking and love for the musical art, Kandinsky had never received any professional education and had significant difficulties grasping even the basics of theory. He therefore had to communicate through musicians, among whom the most prominent was Thomas Hartmann. Hartmann was a composer, pianist, conductor, and private student of Taneyev and Arensky; his alma mater was the Saint-Petersburg Conservatoire, where he had studied under Yesipova.

The pinnacle of their collaboration can be placed at the beginning of the 1910s when they experimented intensely and worked together on several projects, most notably on Daphnis and Chloe and The Yellow Sound.

There is something symptomatic about their attention to Longus's [ $2^{\text {nd }}$ century] novel, Daphnis and Chloe - it was characteristic of the cultural milieu of the beginning of the twentieth century. Work on this composition went on in parallel to Diaghilev and Fokine, but was interrupted. Images from antiquity were also used in a debut work by Aleksandr Sakharov - an innovative dancer who took an active role in making Kandinsky's ideas a reality. Performance took place in Munich in 1910. Music was probably written by Hartmann. That was an indisputable breakthrough in choreography: Sakharov was the first male dancer whose solo act featured themes from antiquity, two years before Nijinsky's famous "Afternoon of the Faun." 
The Russian State Archive for Literature and Art in Moscow holds a draft of the "Suite on antique themes" for string quartet and two harps by Hartmann, and one cannot help but be amazed with the quality of stylization. There are a variety of models that attracted the composer, including the transparent Viennese classical style, rhetorical figures from the Baroque era, the expressive Romantic sound, and something approaching the 12-tone technique. The third movement features a theme known as the Ode of Pindar. The sound world of the string quartet and two harps, on the one hand, helps to create a certain delicacy in the musical writing and, on the other, is used for sharp coloristic effects such as bell-like sonorities in the first movement.

One can find an even more radical sound world in The Yellow Sound drafts. Unfortunately, there is not much left: several sheets of piano reduction including the 5th tableau blueprints, and drafts that cannot be completely attributed. There is also an audio recording, made in the U.S. in the 1950s, on which Hartmann performed music for the stage composition. It lasts about 23 minutes and includes many additional fragments that are not to be found in the drafts. The quality of this recording, however, is far from perfect and does not include the entire composition.

The musical material for The Yellow Sound can be said to go towards extended tonality, beyond a traditional system of tonal relations. Hartmann uses triads as a central element (both minor and major ones), but played at the same time they make tonality less clear and reveal dissonances. There is also wide use of polyharmonic combinations, symmetric modes (notably the augmented one), and the dominance of extreme registers. Some episodes show an interest towards the 12-tone system - single-voiced successions come close to early dodecaphonic oeuvres by Schoenberg. However dodecaphony should feature a lack of repetition within series, which is not something we found in Hartmann. Still one can see the dominance of the rational side.

$\odot$

\subsection{THE COLOR MUSIC OF ALEIRSANDRA UNKOVSIKAYA}

Elena Scherbakova

Professor, State University of Humanities and Social Studies, Department of Music, Kolomna, Russia

The Russian violinist and music teacher Aleksandra Vasilievna Unkovskaya (1857-1927) was close to theosophy circles and became known primarily for her investigations of color and music. Today her name is almost forgotten, 
and its return to readers now can be explained by the fact that Unkovskaya was close to the Vasily Kandinsky circle. In his article "On Stage Composition" and in On the Spiritual in Art, Kandinsky quotes Unkovskaya's article "The Method of colors, sounds and numbers," in which she formulates her methodological task: "to listen to Nature sounds, feeling them through the colors, perceiving its colors through the sounds and in this way to create pieces of art and music."

Unkovskaya's life was closely connected with musical and theosophical circles in Kaluga, Petersburg and Moscow. She studied piano privately with the famous composer and pianist Mily Balakirev, a close acquaintance of her parents.

Unkovskaya's music education system, elaborated on while living in Kaluga, was based on the coordination of colors, sounds and numbers-in other words, the coordination of the seven-color spectrum with the seven-note scale: "Do" red, "Re"- orange, "Mi"- yellow, "Fa"- green, "Sol"- pale blue, "'La"- dark blue, "Si"-violet". This system was presented in her 1909 article, "The Method of colors, sounds and numbers," published in a theosophical journal that later developed these ideas into a series, "A Letter on Music," which ran from 1912 to 1915.

Unkovskaya's system of music education greatly interest Kandinsky. In his letters to Petersburg physician, painter and musicologist Nikolai Kulbin, and to Gabriele Münter, he mentioned his hope to meet Unkovskaya in Kaluga. In On the Spiritual In Art, Kandinsky wrote about Unkovskaya's method and mentioned that it was found to be "useful" at the Petersburg Conservatory.

Kandinsky deeply appreciated thoughtful musicians and tried to establish contact with them. During his preparation of On the Spiritual in Art, the idea of color tones and the problem of color symbolism were at the center of his interests. Skriabin's version of color music was based on "color hearing," an ability the composer had. A good musician and graphic artist, Unkovskaya proposed her version based on the rational numerical principle, which might have been attractive to the artist and the intellectual.

\section{SELECTED REFERENCES}

Reyson, Michail B., Gody žizni i tvorčeskix iskanij (Years of Life and Creative Quest) (Moscow : Sputnik, 2002).

Unkovskaya, Aleksandra V., "The Method of colors, sounds and numbers" (Metoda cveto-zvuko-čisel), in Vestnik teosofii (n $\left.{ }^{\circ} 1,1909\right)$, pp. 77-82.

Unkovskaya 1914: Unkovskaya, Aleksandra V., "Pis'mo o muzyke" (A Letter on Music), in Vestnik teosofii ( $\left.{ }^{\circ} 7-8,1914\right)$, pp. 23-31.

Unkovskaya, Aleksandra V., Vospominaniya (Reminiscences), reprint edition (Kaluga : Fridgelm, 2006). 
THE AUDIOSCENES PROJECT

\author{
Marcus Mota \\ University of Brasilia (UnB), Brazil \\ marcusmotaunb@gmail.com
}

\begin{abstract}
In this essay, I present the assumptions and recent results of the research and artistic achievements of the project being developed at the DramaLab of the University of Brasília, Brazil (LADI-UnB), beginning in 2016. This project deals with orchestrations based on the Kandinsky's "Composition" series.
\end{abstract}

Keywords: Kandinsky. Compositions. Orchestration.

\title{
RESUMO
}

Neste ensaio, apresenta-se os pressupostos e resultados recentes de pesquisa e realização artística de projeto que está sendo desenvolvido no Laboratório de Dramaturgia da Universidade de Brasília, Brasil (LADI-UnB), desde 2016. Este projeto lida com orquestrações baseadas na série de pinturas de Kandinsky chamada "Composições".

Palavras-chave: Kandinsky. Composição. Orquestração.

\section{PRELIMINARY CONSIDERATIONS}

The reflections outlined here are organized around research entitled "Dramaturgy and Multi-sensoriality: Methodology for elaboration of 'audioscenes' for online environments from the 'Composition' series, by Kandinsky." The research project was approved by the National Research Bureau (CNPq) in its Universal Call for Researchers, 2016, but effectively began in the first semester of 2017. Here are presented the ideas and intentions of the research project. In the second half of 2017, with the financial contribution of CNPq, the analysis of paintings and audiovisual scripts began to take effect. In this second phase, the researcher and multimedia artist Alexandre Rangel has been a fundamental interlocutor.

The project proposal was based on the theoretical texts of Kandinsky, the secondary bibliography specific to the theme, and the analysis of a cycle of paintings called "Compositions," in order to perform musical orchestrations 
that dialogue with the images and creative decisions of each frame studied. These orchestrations are not illustrations of the visual works: they are sound scripts for digital interventions into each painting, converging in a video that integrates music with the movement within Kandinsky's visual work. At the end, we will have ten videos for the ten "Compositions" by Kandinsky. At the current stage of the research, we have arrived at half of the project, with the elaboration of five videos, or what we call "audioscenes." Here follows a discussion about the assumptions underlying this research.

\section{NEW DRAMATURGIES}

The relationships between art and technology have found in online environments a field of exploration that requires the redefinition of many assumptions. At first, dramaturgical procedures were applied to these environments in an attempt to transpose to the internet modes of scenic communication based on verbal communication. Just as the first cinema based its relationship between what is shown and the perspective of the viewer from the relationship between stage and audience, in this first phase, electronic dramaturgy shifted the protocols of the spoken theater to the videos available online.

With new possibilities arising from the digitalization of sounds and images, and the synchronization and diversification of social media, the decentralization of the spoken word provided the most diverse sensorial games, transposing to the digital medium the manipulation of information from the most varied sources, as well as the appropriation and transformation of artistic traditions and compositional genres. Thus, motion, sound, color, and objects are correlated in videos present in online environments that, in the end, precisely emphasize the possibilities of manipulation of visual and sound.

Thus, dramaturgical practice here acquires a new feature or rather, resignifies long-lasting activities in the organization of multisensory events, which approaches the ideas and practices of Wassily Kandinsky.

A little known fact of Kandinsky's work is his quest for non-digital means of this multisensory dramaturgy. In addition to making use of musical procedures for the organization of his paintings, Kandinsky was involved, between 1909 and 1912, in developing entirely theatrical projects, such as The Yellow Sound, The Green Sound, Black and White, and Violet. These projects were never realized during the artist's lifetime. But according to the remaining documentation, especially in the case of The Yellow Sound, the stage was to be a space for the emergence of audiovisual stimuli coming from material sources, co-presented to the spectators following this organization and aesthetic basis: 


\section{A. SOURCES OF PERCEPTIONS OR ELEMENTS}

1) musical sound and movement;

2) physical-spiritual sonority and its movement expressed by people or objects;

3) colored sound and movement (a special scenic possibility).

As we can observe, Kandinsky initiates this process from the sound and its various possibilities of articulation as channels of effects production, he also uses the reference of his own work.

Thus, the dramaturgy proposed by Kandinsky is based on its aural definition: what will be presented before an audience is more oriented by its audibility. But at that moment, a dramaturgy so formulated becomes more opaque because of the accumulation of references to what specifies it. If the sound resource seems to be what determines Kandinsky's multisensory dramaturgy, this acoustic hegemony makes it difficult to understand what the artist has in mind. In fact, Kandinsky associates sound with non-auditory contexts, not properly sound contexts, causing this transposition of references and the resulting ambivalences.

Line 1 of Kandinsky's proposal above presents the usual way we perceive sound and how it is produced. At Line 2 we still have sound, but in a different situation: it is another type of sonority, something in opposition and different from the mode of production and reception of Topic 1 . This physical-spiritual sonority is also articulated by bodies and movements, as in Line 1. But its orientation is diverse, it is physical-spiritual, one of the key expressions in Kandinsky's theoretical work, Concerning the Spiritual in Art (1912), which seeks to synthesize his ideas and investigations until the advent of "abstract painting."

From this context, the emphasis on sound and the use of the undifferentiated "physical-spiritual" can be best understood. The search for a broad, multisensorial dramaturgy lies in the aesthetic utopia by new means and fictional universes as opposed to certain social, artistic and political processes in Europe between the late 19 th and first decades of the $20^{\text {th }}$ century. The anti-materialism and antimimetism of this generation drove this demand for the "internal," the abstract.

In this sense, the omnipresence of sound, the sound in everything as object and means, as production and effect, is understood in the elevation of its physical properties to processes of composition and organization of all works. Unveiling the physical nature of sound and its constitution in harmonic series, for example, would make it possible to open a space for starting from similarities - color as a vibration - to propose associations, reconfigurations and new perceptual dynamics. 
Wherefore, the dramaturgy proposed by Kandinsky takes place in scenes that explore such perceptive dynamics. The physical-spiritual is the convergence of effects between the various channels, and the media used.

Thus, the abstract effect of a non-narrative, non-mimetic, nonrepresentational dramaturgy that projects the spectator to planned synaesthetic games, color compositions, sounds, and movements, and approximates what, after the advent of digital resources and cyberculture, would be discussed by Pierre Lévy as the "Virtual."

\section{THE COMPOSITIONS}

It is in this unusual encounter between the project proposed but not entirely realized by Kandinsky, and the horizons opened by the Digital Revolution that this research seeks, returning to historical and expressive processes, to problematize by conceptual discussion and audiovisual production, a multisensorial dramaturgy elaborated from aural inputs from the materiality of amplified sound to non-sound events. As a result, we have the set of paintings called "Compositions" as a target for the "redramaturgies" of this research. This set of ten pictures converges Kandinsky's experiences in favor of multisensory events with the methodology of elaboration of audioscenes for online environments.

Kandinsky proposed at the end of his Concerning the Spiritual in Art a classification of the modalities of his production into three types: Impressions, Improvisations, and Compositions. From the concept and experience of musical composition, Kandinsky called "compositions" something that needed a greater mastery of construction and perceptive tension. They would not be just approximations of a prior reality, like "impressions" or the results of intense and rapid processes, like "improvisations." "Compositions" would designate activities of study, with preparatory stages, prior sketches, and works (elaborated slowly and worked on long-term). The term comes from music. In his memoirs, Kandinsky states: "I was moved internally by the word 'composition' and later I decided to paint a 'composition.' - This words affected me like a prayer - This type of compositional painting would be the most complex production in the visual arts. According to Kandinsky, it could divide the constructive tendencies into painting into two main groups:

1) simple composition, submitted to a clear and simple form, called melodic composition,

2) the complex composition in which various forms combine. The basis of the composition then receives a particular sonority, it is the so-called symphonic composition. 
In his proposal, Kandinsky has in mind an expansion of the visual artist's scope from contact with other arts such as music, literature and the theater. This expansion is based on the emphasis of the organization of materials and their effects. Such a broad perspective emphasizes the work of composition as a space of experimentation whose purpose lies "autotelically," in the very process of seeking contacts between different perceptual fields.

What Kandinsky sought with his paintings can now be summarized by the proposition of what we call "audioscenes," or the use of psychoacoustic parameters as both organizers of aesthetic experience and their reception. The term comes from theoretical frameworks proposed in Sound Studies by Michel Chion. It is not a matter of advocating for the primacy of sound in perceptual processes, but from the properties of aural events, to propose events organized from these properties, events that are not exclusively received by sound channels. Thus, through the audible, we arrive at the non-sonorous, and from it, at a multisensorial event.

The Laboratory of Dramatic Arts of the Universidade de Brasilia (LADI$\mathrm{UnB}$ ), has been working for years from the perspective of production and reflection on audioscenes from the assembling of dramatic-musical works and the reconstruction of dramaturgy procedures in the Greek theater. A point of convergence of these researches was the University of Lisbon post-doctoral program, during which audioscenes were produced for the text of The Ethiopians by Heliodorus. In place of music for theater from musical dramaturgy, for a scene marked by face-to-face interaction between actors and audience, orchestrations were developed from the study of the monumental work of Heliodoro, using techniques in digital orchestration conducted by the Berklee School of Music.

Such orchestrations rely on the expanded palette of a digital orchestra to produce events independent of the material taken as the starting point (the work of Heliodoro) but which project in the symphonic writing, this kind of interpretation and their synesthetic reconstructions.

During the research and elaboration of the audiocenas for The Ethiopians, from the deepening contact with the works and ideas of Kandinsky and of the digital compositional processes, it became clear that in Kandinsky we have an integration of conceptual discussion and artistic production of multisensorial events.

Thus, in Kandinsky's set of paintings and theoretical texts there is a whole "know-how" of the elaboration of works in the interwovenness of procedures and multiple perceptions, which points to reflections and processes that a dramaturgy with digital resources can not only make comprehensible and 
re-applicable, but also provide new lines of research and production in the interfaces between art and technology.

In this sense, the expansion through which the concept of dramaturgy has passed in the last decades ends up supporting the discourse-base of this research and of Kandinsky's own multiplanar utopia. Signs of this are in the multiplication of "new dramaturgies": dramaturgy of the director, dramaturgy of the actor, dramaturgy of light, dramaturgy of dance, and so on.

This broadening of contexts of dramaturgical activity is not limited to the scenic universe. The issue of proposing events for reception is also present in other contexts, such as in virtual environments. A multimedia dramaturgy is now requested in its most diverse and updated forms, ranging from games scripts to the various possibilities of video art.

A possibility for multimedia or digital dramaturgy is found in audioscenes, posted as videos on online platforms for the sharing of audiovisual material (YouTube, Internet Archive, Dailymotion, Facebook). The concept of these audioscenes retakes both the ideas and research of Kandinsky, and the experiments of Oskar Fischinger (1900-1967). In both, the tensions between sounds and images result in audiovisual syntheses that are called "abstract." The complementarity between the aesthetic projects of Kandinsky and Oskar Fischinger points to the strong correlation between what is shown in the media (picture, video) with attempts to produce visual music or an expanded field perception affected by the exploration of psycho-acoustic parameters for the organization of the work.

Thus, abstract art by Kandinsky and Oskar Fischinger is translated as multisensory experiences in which certain properties of sound (pitch, duration, intensity, texture, timbre, spatialization) are used both as compositional elements and as the object of representation itself. This research proposes to try from the horizon opened by Kandinsky's abstraction and its sound-based orientation, to produce and document processes for a dramaturgy that conveys in online environments: audioscenes, experiments that explore sound and image editing tools, and new means of producing tensions between sound and visuality.

The sound scanning has provided access to expressions only dreamed of by Kandinsky and partially realized by Oskar Fischinger. One of the frontiers of digitizing or manipulating sound lies in exploring the potentialities of color. The spiritual resonance theory of color proposed by Kandinsky touches on some of these experiences, which are still open through new technologies in visual design and sound.

For timbre or the "color of the sound," possibilities converge from manipulation, not only of the materials such as combinations of sounds or pigments. In the words of A. Schoenberg in his Theory of Composition (1911): 
In a musical sound (Klang) three characteristics are recognized: its pitch, color timbre and volume. Up to now it has been measured in only one of the three dimensions in which it operates, in the one we call 'pitch'. Attempts at measurement in the other dimensions have scarcely been undertaken to date; organization of their results into a system has not yet been attempted at all. The evaluation of tone color (Klangfarbe), the second dimension of tone, is thus in a still much less cultivated, much less organized state than is the aesthetic evaluation of these last-named harmonies. Nevertheless, we go right on boldly connecting the sounds with one another, contrasting them with one another, simply by feeling; and it has never yet occurred to anyone to require here of a theory that it should determine laws by which one may do that sort of thing. Such just cannot be done at present. And, as is evident, we can also get along without such laws. Perhaps we should differentiate still more precisely, if attempts at measurement in this second dimension had already achieved a palpable result. Again, perhaps not. Anyway, our attention to tone colors is becoming more and more active, is moving closer and closer to the possibility of describing and organizing them. At the same time, probably, to restrictive theories, as well. For the present we judge the artistic effect of these relationships only by feeling. How all that relates to the essence of natural sound we do not know, perhaps we can hardly guess at it yet but we do write progressions of tone colors without a worry, and they do somehow satisfy the sense of beauty (...) Tone-color melodies! How acute the senses that would be able to perceive them! How high the development of spirit that could find pleasure in such subtle things!

In this sense, the audioscenes projected and realized from the pictorial set called "Compositions," by Kandinsky, are precisely in the resumption of this plasticity of the combination of sounds from the restrictions and possibilities of the instruments on the orchestral palette redefined by the operations of its treatment digital.

We come, therefore, to what is the main issue of this research: a dramaturgy, or an integrated set of compositional procedures, that starts from tools of manipulation of sounds and images, to make explicit how imaginaries elaborated from psychoacoustic parameters are organized and can be analyzed, 
appropriated and transformed. The result of this dramaturgy is both a detailed exposition of a documented methodology of this dramaturgical activity and a series of ten audioscenes from Kandinsky's Compositions.

\section{A BIT OF ORDER IN THE CHAOS}

The methodological framework of this research comes from the recent contributions of Art-Based Research, which seeks to construct modes of reflection and organization of intellectual work from specific situations involving agents in contexts of creative processes. Among the possibilities, we have the one characterized by J. Haywood Rolling as an art research methodology that also produces art. That is, a methodology of creative processes that intersect with a research methodology. Thus, common practices but with different objectives such as observation, file generation, proposition and revision of hypotheses, are correlated in a hybrid research.

In this way, as each creative process is unique, hybrid research in art builds its organization and rationality by specifying how the stages of its realization will be executed. Due to the complexity of this research, which integrates several activities and skills, there is a need to sequence the acts of investigation into sets or blocks of actions. For each block, there are one or two methodologies used. What follows is an exposition of what will be done in each of these blocks, with a small discussion that seeks to contextualize the activities and assumptions in question.

Down below we have the blocks/steps of this research:

A. Survey of the textual material in which Kandinsky himself discusses his works and his relationship with music. Kandinsky devoted a portion of his time to expressing ideas about the general processes of elaboration of visual works from modern procedures of musical composition. He left descriptions and comments on his works, especially for Composition II, Composition IV, Composition VI; also in Concerning the Spiritual Art (1910), Point and Line to Plane (1926). Also in his assembled notes for the lessons he gave at the Bauhaus, where he taught between 1922 and 1933, without referring to a specific work, he enumerates common compositional procedures between music and painting.

With these texts as a guide, as pre-compositional indications, would be elaborated orchestral exercises, forming a suite of ten pieces, their numbers being related to the ten paintings Kandinsky called Compositions.

The choice of this group of pieces is relevant in the study of Kandinsky's works. Like Beethoven's sonatas, they are like a diary, part of Kandinsky's artistic development. In the conclusion of Concerning the Spiritual in Art, Kandinsky states the classification of his works: impressions, improvisations, 
and compositions. The latter category includes works that have undergone a longer process of elaboration between sketches and preliminary studies and their final realization. The idea of composition already had a tradition in the plastic arts, based on classical rhetoric. But in Kandinsky, the term "composition" acquires the status of convergence: it would be the mark of the new period in the Arts which, surpassing the limitations of realistic and naturalist painting, would emancipate the painter from utilitarian reasons so that he would focus on the constructiveness of relations; while at the same time it would consecrate the integration between such relationship building and the procedures of music.

Thus in addition to analogies, Kandinsky seeks "composition," "compositional painting" as a visual projection of explorations of a new aesthetic based on the transposition of writing and techniques used in the recording and making of sonically oriented works. Thereby, elaborating orchestral arrangements from the pictures would be the same as exploring Kandinsky's textual and visual stimuli, to explain them and to carry them forward.

B. Elaboration of orchestrations for each one of the ten from the analysis of the picture and the data of the writings of kandinsky

The choice for the symphonic ensemble is linked to Kandinsky's own demands. Discussing constructive tendencies in painting, he divides them, as we have seen, into two groups: melodic and symphonic. In the latter, the complexity in the relations between the elements, entails a creative process that starts from sketches of approximations in which it is little by little restricted and abandons the references to reproduce something externally, with the greater focus on the organization of the space of the picture, of its shapes and distribution of elements. To this, Kandinsky refers as Compositions.

The complexity that the "symphonic" can explore, concerns the two basic features of the pictorial arts according to Kandinsky: form and color. In this sense, the amplitude of the effective orchestration becomes a horizon for the aesthetic project of Kandinsky. For example, the innumerable possibilities of combinations of timbres in an orchestra, the melody of timbres (Klangfarbenmelodie) according to Arnold Schoenberg, finds its counterpart in the research of colors Kandinsky realizes in his pictures and theorizes especially in Concerning the Spiritual in Art and Point and Line to Plane. On the other hand, the problematization of the spatiality of the pictorial art in Point and Line to Plane approaches the multilinearity of the forms and the basic elements of temporal events. In this sense, the old opposition in the arts of temporal and spatial arts, as seen in Lessing's Laocoon, is questioned: painting is capable of working with various temporal references (acceleration, deceleration, simultaneity) just as music does. 
Thus, symphonic composition becomes a model, subtext for compositional painting, by providing an extensive context in which possibilities of combinations of timbres and temporalities can be made explicit.

In this way, when proposing an orchestration for each painting, what is done is not to produce a sound illustration for a pictorial performance, actually what we have is the act of producing, from the compositional elements, a sound exegesis of the elements organization of the picture. That is, one composition responds to another composition. If in order to create his paintings Kandinsky transposed techniques and sonic concepts for a visual product, when proposing an orchestration from this transposition we have the possibility to continue and to extend the interartistic dialogue, going beyond a supplementary approach. For indeed, since Kandinsky's painting is the exploration of an interchange between arts, it is something else - it is neither music nor painting. It is the production of a multisensory experience distinguishable itself. The transposition is not unilateral: the new medium for the old procedure ends up determining new resources. Thus, producing orchestrations for Kandinsky's paintings will also be an exercise in exploring such multisensory experiences in music.

For instrumentation, it was decided to combine Schoenberg's guidelines, which reduces a chamber model orchestra to a more diversified percussive section to translate many of the effects of points, graphs, and broken lines into the frames.

Schoenberg is more precise about this aspect of orchestration in his essay Composing with Twelve Tones (1941):

A work for orchestra must necessarily be composed of more voices than one for a smaller combination. Of course, many composers can manage with a small number of voices by doubling them in many instruments or in octaves, by breaking and doubling the harmony in many ways - sometimes thereby obscuring the presence of a content, sometimes making its absence clear. It must be admitted that most orchestral combinations do not promote what the artist calls unmixed, unbroken colors. The childish preference of the primitive ear for colors has kept a number of imperfect instruments in the orchestra, because of their individuality. More mature minds resist the temptation to become intoxicated by colors and prefer to be coldly convinced by the transparency of clear-cut ideas. Avoidance of doubling in octaves automatically precludes the 
use of broken harmonies which contribute so much to the pleasant noise that is today called "sonority." Since I was educated primarily by playing and writing chamber music, my style of orchestration had long ago turned to thinness and transparency, in spite of contemporary influences.

\section{AUDIOSCENES}

After this, we will have the visual treatment phase of the paintings of the Compositions group. With the sound files resulting from orchestrations, audioscenes or videographies will be drawn up synchronizing with music produced with parts of the focused frames. As the frames from the Compositions do not have narratives or explicit representational motivation but rather colors, forms, and traits, these are the elements that will be emphasized by the "orchestral suite" - a set of ten orchestrations.

In this way, the orchestral score is a screenplay of moving images, a first redrawing of the re-dramaturgies from Kandinsky's material, from his theoretical proposals and analysis of frames. This correlation between the succession of songs and the succession of sections of the frames causes mutual clashes between the sound and the image: both are clarified, building an expanded field of perceptions.

In another way: the orchestral compositions will be digitally processed generating sound files. These compositions were elaborated from the confluences of the information of theories and propositions of Kandinsky for visual representations from psychoacoustic data. When the composition/ orchestration is finalized and the sound file is produced, this sound file in its continuity presents a command to read and interpret the frame data. This data will be used in the production of videography that follows the order of the sound events presented in the compositions/orchestrations, emphasizing at every moment what is referred to in these audio files, from video-mapping techniques.

The end result is an audiovisual file mixed with the track and visual images synchronized to be distributed on the world wide web. The resultant video or audioscene is an immersion of the observer in the details of painting from a script previously chosen in the set of data from the analysis of the paintings and concepts proposed by Kandinsky.

\section{RESULTS}

After the first year of research, the following audioscenes have been performed: 


\begin{tabular}{|c|c|c|c|}
\hline NUMBER & SOURCE & DURATION & HINK \\
\hline 1 & Composition IV & $5 \mathrm{mins} 29 \mathrm{secs}$ & https://youtu.be/-Ph55ofz94c \\
\hline 2 & Composition VI & $5 \mathrm{mins} 04 \mathrm{secs}$ & $\begin{array}{l}\text { https://youtu.be/ } \\
\text { BvTonmWXFnA }\end{array}$ \\
\hline 3 & Composition VIII & 3 mins $26 \mathrm{secs}$ & https://youtu.be/JM1Hv2fSjok \\
\hline 4 & Composition V & $3 \mathrm{mins} 42 \mathrm{secs}$ & $\begin{array}{l}\text { https://www.youtube.com/ } \\
\text { watch?v=HjGxNd9EMeo }\end{array}$ \\
\hline 5 & Composition II & 3 mins 29 secs & $\begin{array}{l}\text { https://www.youtube.com/ } \\
\text { watch?v=fvdqIQnkACQ }\end{array}$ \\
\hline
\end{tabular}

As can be seen, it doesn't follow the order Kandinsky prepared the cycle of works in. Our starting point was to work with the paintings about which Kandinsky himself had written something. In his theoretical texts, Kandinsky focuses more on general aspects of visuality and an aesthetic common to all arts. As much as an artist's writings always have a self-analytical coloring, even when he does not refer to himself, it is nevertheless noteworthy when there is a text directly attached to his own work. In happy and rare occasions, Kandinsky opened the black box and gave us explicit textual access to his creative process.

Because of this, we began the project with the analysis of Composition IV. This beginning also established some parameters for the later compositions: the whole process was documented in a follow-up blog, which gave an overview of points of interest for musical composition from the analysis of both Kandinsky's texts and the painting itself. After analyzing these textual and visual data, a script was produced with the succession of figures or moments that would be the basis for the orchestration. In the case of Composition IV, it was concluded that the picture was divided into two main halves: the one on the left marked by war images and the one on the right indicating peace, especially in the figure of lovers. In the middle, the frame is cut by a vertical scratch that crosses the edges of the screen. Then the following macrostructure of the music was proposed: section A, as a theme related to this vertical cut, identified by juxtaposition extreme treble and bass; section $B$, interpreting the march of horses and horsemen and their confrontation duplicated by the confrontation in the natural world, as in the images of the sea in fury and the world, to the avaricious ones (mountains and waters changing places); section $\mathrm{C}$, with the calm of seduction among lovers, a few moments deepened with humor. From this macrostructure the order of these sections was elaborated: $A B A C A$. The short section A would give coherence to the orchestration, as a zero point, a return to the tension between the high/low ends. 
In this first phase, we saw that using an existing Kandinsky text was a very productive strategy, which was resumed in Composition VI. Kandinsky's text on Composition VI was more elaborate than the one on Composition IV, providing more information for creative decisions. In addition, this strategy presents another problem: the Compositions of this phase of Kandinsky had relations between them, like expanding a vocabulary of images. An aesthetic retort to this would be to establish a set of musical themes that would go across the orchestrations. But, in order to avoid a close coherence with procedures of the sonata form, I decided to maintain the autonomy of musical works, and in some cases, to use citations or reformulations of materials used.

This decision was important to me because, in the intensity of the project flow, the activities of studying, composing, and producing the video would have to make options that at the same time were linked to a work in question and to the whole cycle. That is, in addition to the macrostructure of each work, I would have to keep in mind the macrostructure that encompassed all the orchestrations.

Back to Kandinsky, we see that the same creative process of the Compositions cycle was discontinuous, closely related to the contexts of production, to the aesthetic and existential changes of the Russian painter.

\begin{tabular}{|c|c|c|}
\hline NUMBER & DATE & CONTEXTS \\
\hline 1 & 1910 & Munich. Lost during World War II \\
\hline 2 & 1910 & Munich. Lost during World War II \\
\hline 3 & 1910 & Munich. Lost during World War II \\
\hline 4 & 1911 & Munich \\
\hline 5 & 1911 & Munich \\
\hline 6 & 1913 & Munich \\
\hline 7 & 1913 & Munich \\
\hline 8 & 1923 & Bauhaus \\
\hline 9 & 1936 & Paris \\
\hline 10 & 1939 & Paris \\
\hline
\end{tabular}

The first seven Compositions mark the most radicalized movement for abstraction and musicality, having been composed per a four-year period. The images of the knights and their horses, the mountains, the walls of Russian cities gradually come undone, in favor of a juxtaposition of lines and colors. Composition IV is in the middle of this process: it picks up visual elements 
present since Composition I, and already indicates more bold options like those seen in Composition VI and especially in the complex Composition VII.

After composing the orchestration and video for Composition VI, I saw that my method of composition had to be changed: I no longer needed to work with Kandinsky's texts as a starting point and I could go beyond this set of works of the Munich phase. The question for me initially was to throw myself totally into a dark room. But this was instrumental in getting rid of the possible pitfalls of working out orchestrations that were very much anchored in the work I was analyzing. Now, after two orchestrations, I should have been more confident - more enlightened - that my task was never to transpose a painting into music, but to re-capture the impulses of a visual work and then compose it. This detachment, and change of posture, I came to experience from working with Composition VIII.

The work itself seems less ambitious than the two immediately preceding ones. Then there was this conjugation between Kandinsky's work and the changes in the creative process of the audioscenes. In fact, this understanding of the changes in both the Compositions and the audioscenes cycles led to the proposition of a larger script that are the ones of the next audioscenes: I saw that, in fact, I would have to leave for a later moment the compositions of both the works of Paris and the dreaded Composition VII. Of this, there would clearly be two orders of achievement: the final order of the product, with the audioscenes presented in the chronological and numerical order of Kandinsky's Compositions, and the inner order of the creative process of the audioscenes. So it came clear to me that the following sequence would guide me:

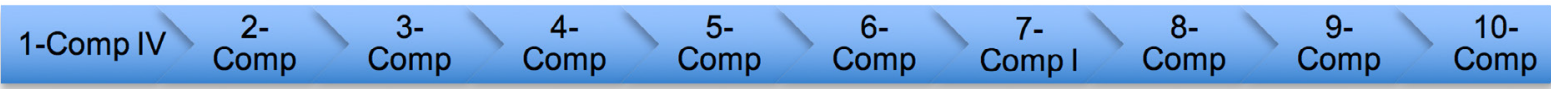

Also from the work with Composition VIII it was clear that I could work with two major instrumentation decisions: 1 . to use more percussion, since Kandinsky uses references to the shamanic universe in his paintings, as Peg Weiss revealed in her brilliant investigation, Kandinsky and Old Russia. The Artist as Ethnographer and Shaman (1995); 2. to change the instrumentation to each work, inserting new instruments and/or redefining existing ones.

Later, after working with Composition $V$, the great challenge was to work with the pieces that were destroyed during the Second World War. For all other Compositions, there was a high-quality reproduction that was analyzed from the image editing software Adobe suite. This process of working with 
something that no longer exists or that exists partially in black and white reproductions and sketches has intensified the fact that we are working at an intersection between data and speculation. At no point did we think we would be developing the exact music for a painting. In dealing with signs of a work that no longer exists, we are pointing to the creative process even as it appropriates and transforms pre-existing materials.

Still, the use and study of sketches has increasingly approximated the musical composition of the activity of giving expression and organization to these materials often poorly understood. The usual emphasis on results rather than on process entails a referential illusionism: many think that the understanding of a work is restricted to the actuality of its disposition before us. I had experienced in loco some works of Kandinsky for the first time during the exhibition Everything Begins at a Point, curated by Evgenia Petrova and Joseph Kiblitsky in 2015; I was struck in an inexplicable manner by diverse sensations and emotions that reverberated in me. As if I was possessed, it put deep and primitive stimuli and memories inside me. There was something so attractive about one of those pictures exhibited, and beyond it too, it awoke in me a desire to experience something close to the canvas and beyond it. And it was a fusion of feelings and senses: colors, sounds, and touch. An irresistible appeal. - Now here we are, impelled by something, although I don't know exactly what, going somewhere I don't know yet. What I know is that this place is found in the timbres and movements of symphonic writing -.

\section{LINKS}

1. Blog Project https://kandinsky2017.blogspot.com

2. Further papers on Music and Theatre by Marcus Mota https://brasilia.academia.edu/MarcusMota

3. Website of Alexandre Rangel http://www.quasecinema.org/ 


\title{
D. DANCE
}

\section{BEWEGUNG/TANZ}

Jelena Hahl-Fontaine

\begin{abstract}
In his famous manifesto, On the Spiritual in Art, Kandinsky also wrote about Movement and Dance, in connection with his young friends, the modern dancer Alexander Sacharoff and the composer Thomas de Hartmann. He experimented with them on the translatability of visual art into music and from music into dance.
\end{abstract}

Keywords: Translatability. Visual art. Music. Dance.

\section{RESUMO}

Em seu famoso manifesto Sobre o Espiritual na Arte, Kandinsky também escreveu sobre Movimento e Dança, em conexão com seus jovens amigos - o dançarino moderno Alexander Sacharoffe o compositor Thomas de Hartmann. Juntos, eles experimentaram possibilidades de tradução da arte visual em música, e da música em dança.

Palavras-chave: Tradutibilidade. Arte Visual. Música, Dança.

Dem sehr genau beobachtenden Künstler ist aufgefallen, daß Bewegungen, deren Sinn man nicht versteht, eine größere Faszination ausüben, daß sie "bedeutend, geheimnisvoll, feierlich" wirken "solange man das äußerliche, praktische Ziel der Bewegung nicht kennt. Dann wirkt sie als reiner Klang” Auch hier wird Kandinskys Tendenz zur Abstrahierung deutlich.

Wie intensiv er sich theoretisch speziell auch mit dem Tanz beschäftigte, zeigt eine Passage aus Über das Geistige in der Kunst. Aus den verschiedenen Manuskriptfassungen geht hervor, daß die folgenden Überlegungen ganz zum Schluß, also 1911 kurz vor Drucklegung, hinzugefügt worden sind:

"Der Ursprung des Tanzes ist scheinbar rein sexueller Natur. Jedenfalls sehen wir noch heute dieses ursprüngliche Element im Volkstanz entblößt liegen. Die später entstandene Notwendigkeit, den Tanz als Mittel zum Gottesdienst zu gebrauchen (Mittel zur 
Inspiration), bleibt sozusagen auf der Fläche der angewandten Ausnützung der Bewegung. Allmählich bekamen diese beiden praktischen Verwendungen eine künstlerische Färbung, die sich durch Jahrhunderte entwickelte und mit der Sprache der Ballettbewegungen endete. Diese Sprache ist heute nur wenigen verständlich und verliert immer an Klarheit. Außerdem ist sie für die kommende Zeit viel zu naiver Natur: sie diente eben nur dem Ausdrucke der materiellen Gefühle (Liebe, Angst usw.) und muß durch eine andere ersetzt werden, die imstande ist, feinere seelische Vibrationen zu verursachen. Aus diesem Grunde haben die Tanzreformatoren unserer Zeit ihren Blick zu vergangenen Formen gewendet, wo sie auch noch heute Hilfe suchen. So entstand das Band, welches Isadora Duncan zwischen dem griechischen Tanz und dem kommenden anknüpfte. Dieses ist also aus demselben Grunde geschehen, aus welchem die Maler bei den Primitiven Hilfe suchten. Natürlich ist es auch im Tanz (ebenso wie in der Malerei) nur ein Übergangsstadium. Wir stehen vor der Notwendigkeit der Bildung des neuen Tanzes, des Tanzes der Zukunft. Dasselbe Gesetz der unbedingten Ausnützung des inneren Sinnes der Bewegung, als des Hauptelementes des Tanzes, wird auch hier wirken und zum Ziele bringen. Auch hier muß und wird die konventionelle, Schönheit' der Bewegung über Bord geworfen und der ,natürliche' Vorgang (Erzählung = literarisches Element) als unnötig und schließlich störend erklärt. Ebenso wie in der Musik oder in der Malerei kein ,häßlicher Klang' und keine äußere, Dissonanz' existiert, d.h. ebenso wie in diesen beiden Künsten jeder Klang und Zusammenklang schön (= zweckmäßig) ist, wenn er aus der inneren Notwendigkeit stammt, so wird bald auch im Tanze der innere Wert jeder Bewegung gefühlt, und es wird die innere Schönheit die äußere ersetzen. Den ,unschönen' Bewegungen, die jetzt plötzlich schön werden, entströmen sofort eine ungeahnte Gewalt und lebendige Kraft. Von diesem Augenblick an beginnt der Tanz der Zukunft.”

Kandinsky nennt nicht Sacharoff, sondern Isadora Duncan, weil diese schon viel bekannter war; er selbst hat sie in München tanzen sehen, vielleicht mehrere Male; denn seit Ende 1902 erwähnt er sie schon in seinen Briefen an Gabriele Munter (Briefe in der GM/JE-Stiftung, München). Sacharoff dagegen war erst seit 1910 wenige Male öffentlich aufgetreten. Doch es war Alexander 
Sacharoff, der bald genau das verwirklichte, was Kandinsky als zukünftiges Ziel des Tanzes beschreibt: auch die feinsten Gefühle durch Tanz auszudrücken, indem der Körper zum Instrument der Seele wird; den Tanz aus der Sphäre des nur Dekorativen, Illustrierenden und Unterhaltenden herauszuführen und zu einer vollwertigen Kunstform zu erheben.

Kandinsky erinnert sich noch 1921 in Russland an seine Synästhesie-und Synthese-Experimente mit Thomas von Hartmann und Alexander Sacharoff in den Jahren ihrer Zusammenarbeit an den Bühnenkompositionen, also Ende 1908 und 1909 in München:

"Ich habe im Ausland zusammen mit einem jungen Musiker und einem Tanzkünstler experimentiert. Der Musiker suchte aus einer Reihe meiner Bilder dasjenige aus, das ihm in musikalischer Hinsicht am klarsten erschien. In Abwesenheit des Tänzers spielte er dieses Bild. Dann kam der Tänzer dazu, ihm wurde das Musikwerk vorgespielt, er setzte es in Tanz um und erriet danach das Bild, das er getanzt hatte ("Vortrag des Malers Kandinsky”, in: Vestnik rabotnikov iskusstv. Nr. 4-5, Moskau 1921, S. 74 f).”

Wer sich speziell für das Phänomen Synästhesie interessiert (echte, unechte Synästhesie und zwischen welchen Kunstformen usw.), findet in der Dissertation von U. Eller-Rüter mehrere Seiten mit ausführlichen Untersuchungen (U.M . Eller - Rüter, a.a.O., 5. $26 f$ Ebenso bei Roger Forloff, a.a.O).

Bevor Kandinsky sich nach längerer Unterbrechung (Weltkrieg. Rückkehr nach Moskau, neue Rückkehr nach Deutschland ans Bauhaus) wieder aktiv seinen Bühnenarbeiten widmet, zeigt sich sein grundsätzliches Interesse am Tanz und an den Prinzipien von Bewegung in den bemerkenswerten
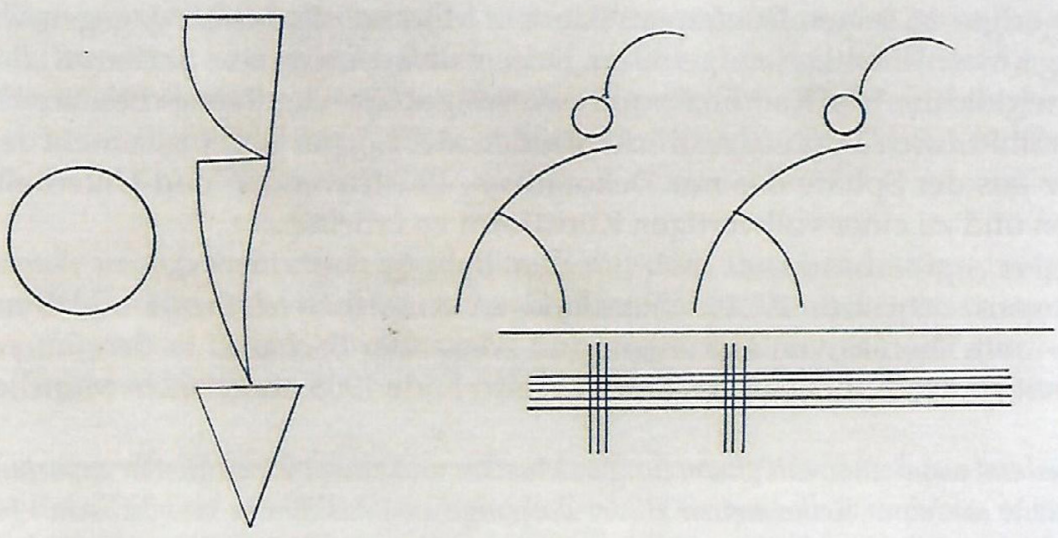

Schemaskizzen, die er zum 'modernen' Tanz von Gret Palucca anfertigt (Fig. 1). Nach Fotos zeichnet er hier Diagramme, ähnlich denen für seine Bildkompositionen: Die Bewegung, die Hauptachsen des Körpers und die Spannungen sind durch verschieden starke Linien 'erklärt'. Eine dieser
Fig. I Kandinsky, Zeichnung Nr. 6, 1929, Tusche/Papier. Sammlung Jelena und Marcel Fontaine $\odot$ SABAM Belgium. 
Analyse-Zeichnungen hat er in seinem zweiten theoretischen Hauptwerk Punkt und Linie zu Fläche, weitere vier im Kunstblatt, beide im Jahre 1926 veröffentlicht. - In ihrer konstruktiven Abstrahierung und Konzentration auf das Wesentliche können diese Diagramme mit einer ganzen Reihe selbständiger Zeichnungen aus derselben Periode verglichen werden, wie zum Beispiel mit der hier abgebildeten, die ebenfalls etwas Tänzerisches und Theatralisches hat. 


\title{
2. KANDINSKY AND DANCE PHOTOGRAPHS:
}

\section{APPLYING A COMPARATIST METHODOLOGY}

Lee Edgar Tyler

\begin{abstract}
This essay applies a comparatist methodology to Charlotte Rudolf's Bauhausera photographs of the German expressionist dancer, Gret Palucca - photos Kandinsky used to illustrate his theories as expressed in his 1926 Point and Line to Plane and Dance Curves: On the Dances of Palucca.
\end{abstract}

Keywords: Kandinsky. Palucca. Comparatist.

\section{RESUMO}

Este artigo aplica uma metodologia comparatista a fotografias elaboradas por Charlott Rudolf a partir do movimentos do dançarino expressionista alemão Gret Palucca, fotos estas que Kandinsky utilizou para ilustrar suas teorias registradas no livro Ponto e Linha sobre o Plano (1926) e no texto "Tanzkurven: Zu den Tänzen der Palucca”, também de 1926.

Palavras-chave: Kandinsky. Palucca. Comparativismo.

$\odot$

\section{INTRODUCTION}

This essay explicates Kandinsky's development of a "dialect" or "idiolect" of the standard method of dance description. This was partly inventive and decorative, and partly constrained by the dance annotations form. This is similar to the constraints oral traditions place on poets: lots of room for individuality, but very strict rules. I suggest a "reading" of Kandinsky's work informed by this commonality.

Although Ernst Gombrich dealt with the relationship of literary and pictorial arts from the Receptionalist approach, practically nothing has been written on tying Iser and especially Foley to pictorial art. Especially as a "set of cognitive categories," which is what I find most significant about Kandinsky's works under study. As for a narrative of my own thought processes as I undertook the task: suffice it to say I unwittingly applied comparatist methodology (understandable, since it's my training) and came to the realization that it worked. And was delighted! A "eureka" moment. 
My mentor John Miles Foley approached me as a sounding board back in the late 1980s, and over a period of a couple of years while I was managing editor of the journal Oral Tradition he worked out a comparatist methodology for ancient and medieval texts that show "oral derivation" (the Iliad, Odyssey, and Beowulf) with the living Balkan oral tradition, which consists of two genres, the Christian and the Muslim. Since the Christian songs are performed at different times than the Muslim, the Muslim songs are much longer, occasionally in excess of the length of the Iliad and Odyssey. His work is primarily encapsulated in his book Immanent Art (1991). It forms the basis of my methodology regarding Kandinsky.

\section{THE METHOD}

To elucidate that method: Foley takes Iser's approach to texts and applies it to oral tradition, and to perform the task of comparison he invented the following principles:

1. Tradition Dependence: The consideration of the poetic "rules" that govern the structure of the work on a general, tradition-specific level.

2. Genre Dependence: The consideration of the poetic "rules" that govern the genre of the work, such as epic narrative, lyric, incantation, etc.

\section{Text or Performance Dependence:} The consideration of the particular text(s) of the work: where it was performed, the singer (if known), the manuscript (if it's a written work), etc. [There are some other things that only deal with oral traditional texts and are irrelevant to my study regarding Kandinsky.]
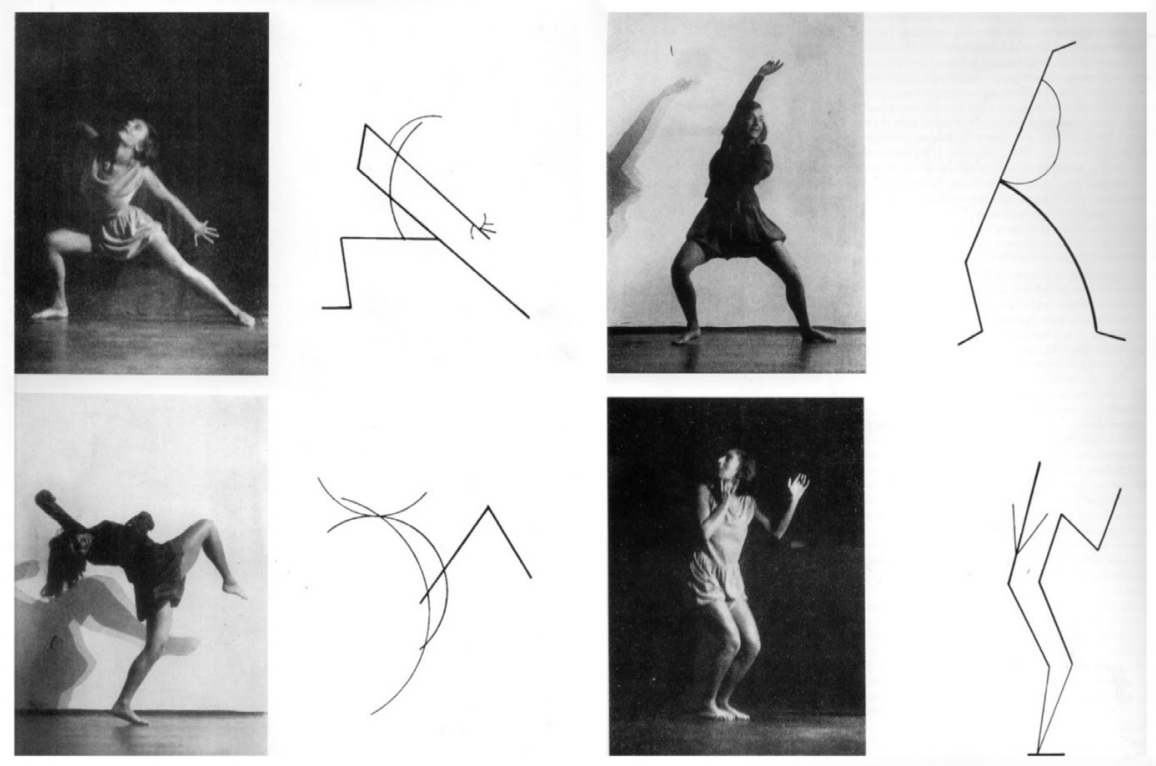

Now, as to Kandinsky's drawings of Palucca, we can see very clearly, one could almost say at first glance, that the Tradition is the Western tradition of abstraction in expressionism (although they're not purely abstract, but representational), specifically Bauhaus in the 1920s. But what does this mean and more importantly how does it inform our "reading" of the drawing. Of course it ties in to Kandinsky's Point, Line, and Plane. And in terms of Genre Dependence, these works are pretty much sui generis, yet tied to the fact that Kandinsky was in many ways his own "tradition." 
In the area of Genre Dependence, of course, Kandinsky was undertaking something new; as I've mentioned before the situation he faced was very much like an oral poet creating a new song in its constraints. He was constrained by the already-existing "shorthand" for dance, and also by his subject matter, just as the oral poet is constrained by his poetic language and the need to fit generally commonplace words into a meaningful narrative. This, to me at least, is the most important aspect of my study.

Text or Performance is in this case the application of the methodology to the individual works.

○

In 1926, Kandinsky published two works which articulated the status of his theories on form: Point and Line to Plane, and Dance Curves: On the Dances of Palucca. These were published about halfway through the lifespan of the Bauhaus, and I am convinced that it was his tenure at the institution that planted the seeds of his ideas expressed in Point and Line to Plane and in Dance Curves. The Bauhaus was an interdisciplinary school, and as such studied modern dancers and often collaborated with them, which Kandinsky naturally found attractive. Dance Curves is an essay containing four drawings referencing four photographic images of the dancer and choreographer Gret Palucca, all of which were the work of the prominent German dance photographer Charlotte Rudolph. Kandinsky wrote that his works demonstrate the "simplicity of the whole form" and the "construction of the large form." Although it is seldom mentioned, in my opinion the photographs of Rudolf masterfully capture the moments in Palucca's dances in which the motion (and emotion) has reached a high point. Hence these photographs served Kandinsky well in his quest for subject matter to illustrate his theories.

As a comparatist, I naturally considered the comparatist's three "elements": Tradition, Genre, and Text or Performance, which were first formally articulated by my mentor, John Miles Foley, in his book Immanent Art. In fact, I applied these elements to both Palucca and Kandinsky in an effort to see what, if any, distinctions I should draw between the two. In a comparatist's terms, the Tradition element is the Bauhaus (especially for Kandinsky, and although Palucca was not a member of the faculty of the Bauhaus, she was the leading figure in German expressionist dance). This is significant, in that a key component of the Bauhaus esthetic was the "minimization of subject matter," which will play an important role in my discussion below. Dance Curves is sui generis or at least was upon its creation. Not only had no one ever worked with photographs of a dancer to create line drawings of their subject before, but Kandinsky was also 
doing it for the express purpose of using dance to articulate his own theories of composition and form. And the Text or Performance element bears examination, as neither Palucca nor Rudolf expected the photographs to see the use to which Kandinsky put them. Is there a tension here? If so, what is its character?

In this essay, I shall apply these elements to a single drawing of a single photograph, and suggest that my readers do the same to the others. In such endeavors, there is no "right" response (although there can conceivably be wrong ones). Different readers will, and should, have different responses and place different emphases on different aspects of any work of art, especially the expressionism of Kandinsky. Before undertaking this application, further word regarding methodology is necessary.

In Immanent Art, John Miles Foley was wrestling with the problem of a critical approach to oral performances and oral-derived texts, specifically from a comparatist point of view; in it, he adopted the "reader receptionist" theories of Wolfgang Iser, who held that literature exists as art only when a reader actively engages it. Otherwise, it is an artifact, a closed book on a shelf in a library. Foley adapted Iser's notion of the "Implied Reader" to an "Implied Audience," and made appropriate adjustments to his studies to accommodate the inherent differences between readership of literary texts (which is an exceedingly private affair) and the aural reception of narrative songs by a group audience in primary oral traditional cultures. This is both public, in that the people are grouped together, all listening to a singer perform; and private, as each individual has his or her vision of the events narrated by the song going through his or her mind as the performance progresses.

But what does narrative, written or sung, have to do with Kandinsky's drawings of Rudolf's photographs of Gret Palucca's dances? It was Ernst Gombrich whose 1972 book Art and Illusion applied an approach to pictorial art, concluding that the representation of reality in drawing and painting is "a transposition, not a copy." As he convincingly demonstrated, pictorial arts make no attempt to "photograph" their subjects, but rather transpose them into a "limited, agreed-upon code" through which the viewer reconstructs a representation of reality. As Gombrich himself expressed it:

"The artist cannot copy a sunlit lawn, but he can suggest it. Exactly how he does it in any particular instance is his secret, but the word of power which makes this magic possible is known to all artists - it is "relationships."

The interaction of these relationships is not a merely convenient method of representation, but rather a set of cognitive categories; as Gombrich mentions, 
the invisible and immaterial "contract" between artist and viewer demands that both participants perceive according to these categories, and in fact cannot share perception without them. Thus it is that Kandinsky can draw, with a mere five angular lines, a representation of Palucca's pause in a dance accessible to any person who is aware of the "rules" Kandinsky followed.

As I mentioned above, Kandinsky's Tradition was the Bauhaus (within the broader tradition of German expressionism, which fits like a Russian doll into the

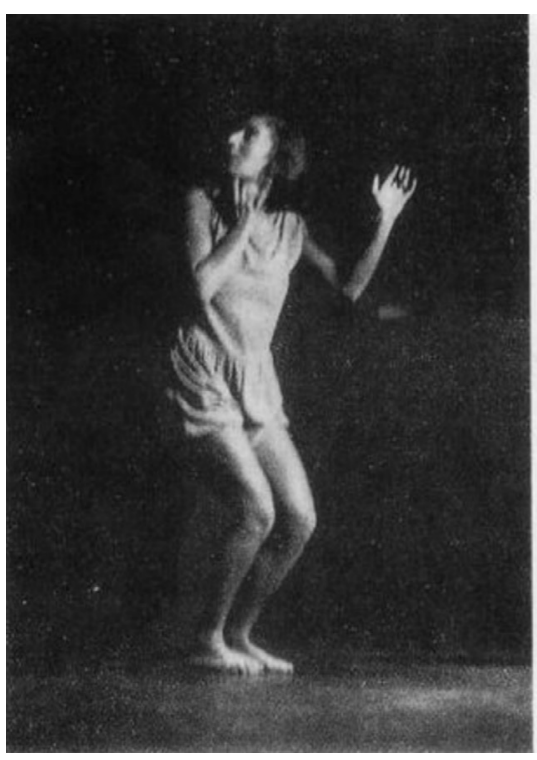
tradition of Western art); and inherent in the Bauhaus tradition is the "minimization of subject matter." He employs a mere five lines, only two of which are angular, to represent Palucca's figure: A single, short, line for her feet; the two, angular, lines for her body; and two short lines for the bend of her right arm. The angles of the two body-lines correspond to Palucca's pose in only the most general way possible (her bent knees and lifted left arm). The angle of her right elbow is portrayed by the two short lines, which together appear as a downward-pointing arrow. There is no hint of the position of her face and head; indeed there is not even a hint in Kandinsky's drawing that they exist. Yet the depiction of Palucca's pose is complete. The question is posed: What is the significance of the absent head in a drawing confessedly intended to demonstrate the "simplicity of the whole form"?

Now, this single work is part of an ensemble of line drawings accompanying photographs; the other three have lines suggesting or representing the position of the face and/or the attitude of the head. What we can say with certainty is that the missing head in this case is deliberate and atypical. It remains to me one of the many mysteries associated with Kandinsky's art.

As I mentioned in the introductory portion of this essay, Dance Curves was sui generis, at least when it was first published. No one had ever worked from photographs of a dancer to produce line drawings before. We are therefore fortunate that Kandinsky produced four such drawings, which permits comparisons, and questions that might be profitable, although ultimately unanswerable.

There is a second generic consideration, in that Kandinsky used the technique evident in Dance Curves while he was a teacher at the Bauhaus: His classroom was very near the dance studio, so he took his students to draw the dancers using only lines and points, and gave them only ten seconds to
Fig. 2 Palucca. Dance Curves.

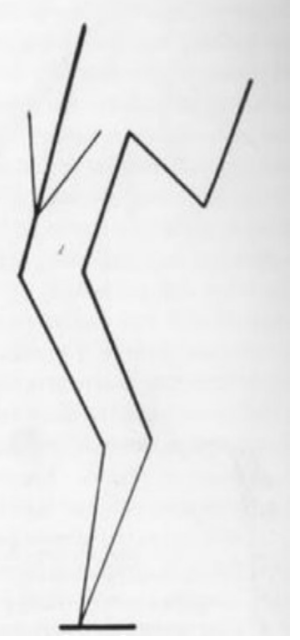


complete each drawing. While this fact is interesting from a pedagogical point of view, I do not consider it essential from a critical perspective: I see it as evidence that Kandinsky's

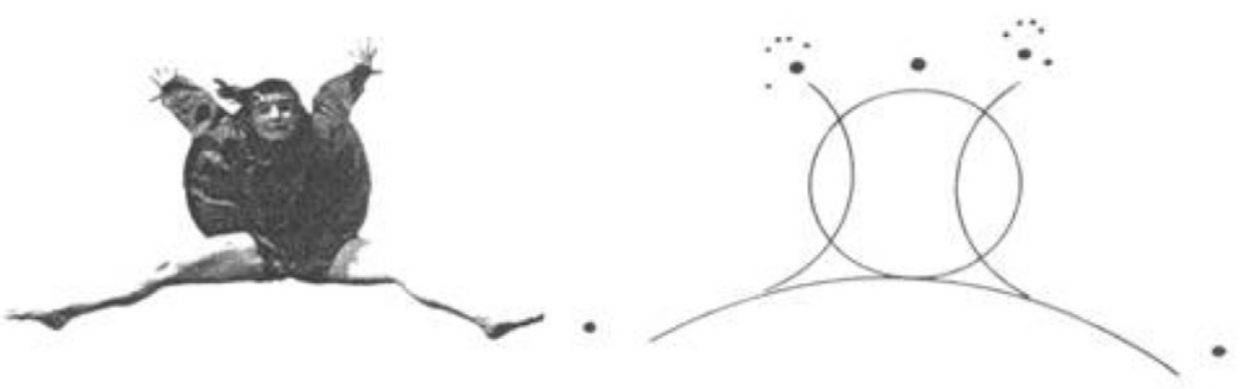
experimentalism extended to his teaching, but the works of Dance Curves would be worthy of a critical approach without it. I'm looking for the Performance element... is it here?

Fig. 3 Palucca. Point and Line to Plane.

There is, however, a fifth such drawing incorporated in From Point and Line to Plane: Palucca is jumping, facing the camera, arms and legs spread. There are five points separate from the line drawing, denoting her feet, hands, and head. Her body, enlarged by her clothing, is denoted by a circle; her arms and legs by arcs. It is Kandinsky's only drawing of Palucca via Rudolf's photography that incorporates a completed circle. It is also the only one that uses points to denote body parts. I feel that this drawing can serve for comparative purposes even though it is not incorporated into Dance Curves, but that it must be set apart (as Kandinsky did set it apart) both structurally, as noted, and aesthetically. It is the only drawing he accomplished of Palucca "in action," as she is momentarily suspended at the height of her jump, whereas the other four drawings show her (more or less) in repose in the course of her dance.

There must always be a tension between a three-dimensional subject and its transposition to a two-dimensional drawing, even in photography. It is, I think, important to consider that Kandinsky's Dance Curves plays against this tension as his drawings minimalize their subject matter, most of which have no corresponding elements in the drawings. By the association of lines with the poses of a dancer, Kandinsky captures what is, to him at least, the essence of a distinct and separate art form. 


\title{
3. KANDINSIKY AND THE NEW DANCE \\ Irina Sirotkina
}

\begin{abstract}
Interested in both the synthesis of the arts and the multi-sensorial experience, synaesthesia, Kandinsky could not pass over dance in his studies. He introduced abstract movement as an important element of his analysis, and he hoped that, by contrast with classical ballet, modern dance would contribute to the new art of abstraction.
\end{abstract}

Keywords: Dance. Movement. Abstraction. Synaesthesia.

\section{RESUMO}

Interessado tanto na sintese das artes quanto na experiência multissensorial, sinestética, Kandinsky não conseguiu se aprofundar na dança em seus estudos. Ele introduziu o movimento abstrato como um importante elemento de suas análises, e esperava que, em contraste com o ballet clássico, a dança moderna pudesse contribuir para a arte nova da abstração.

Palavras-chave: Dança. Movimento. Abstração. Sinestesia.

$\odot$

Kandinsky was not interested in classical ballet, which, he thought, was incapable of expressing a wide range of emotions. For subtler feelings, the artist believed, a new language and a new, modern dance were needed. In Munich, where around 1910 a great many experimental dancers performed, Kandinsky could get a clear picture of what modern dance would be. In their search for a new dance idiom, the Wiesenthal sisters turned towards folk dances, Isadora Duncan turned towards antiquity and yet others looked for completely novel aesthetic and new steps. Later in Germany, Kandinsky sketched the movements of Gret Palucca, the "expressionist" (Ausdruckstanz) dancer, and he mentioned her in his treatise, Punkt und Linie $z u$ Fläche. He found her split jumps, in which the five ends of the body formed five points, to make a contrast with the ballet grand jeté, which he saw as similar to a horizontal line.

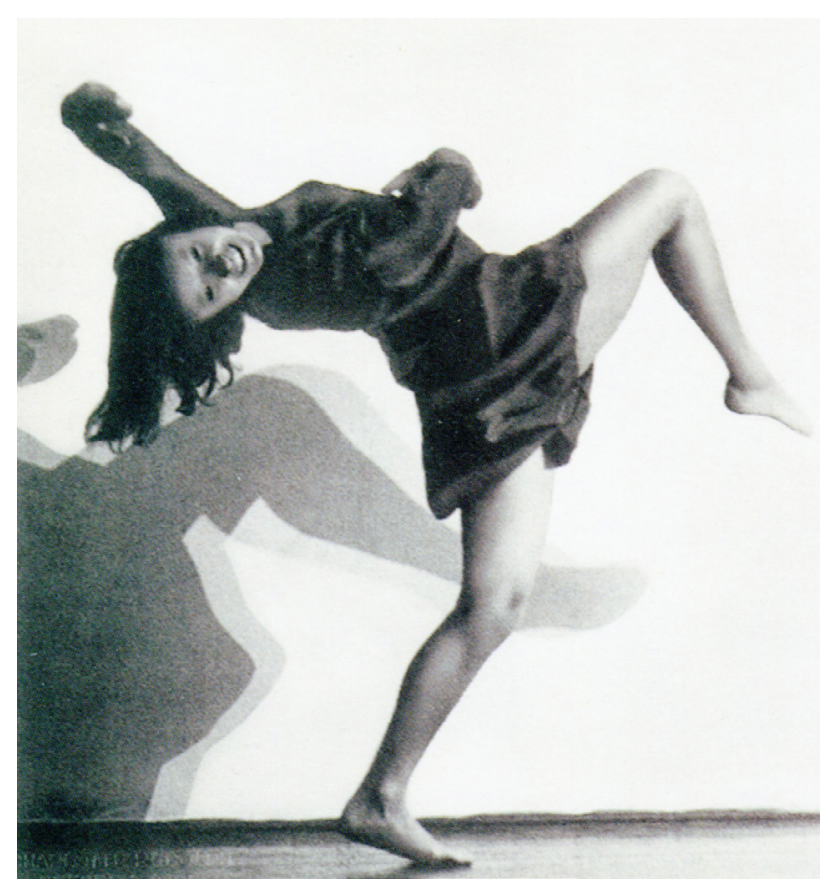



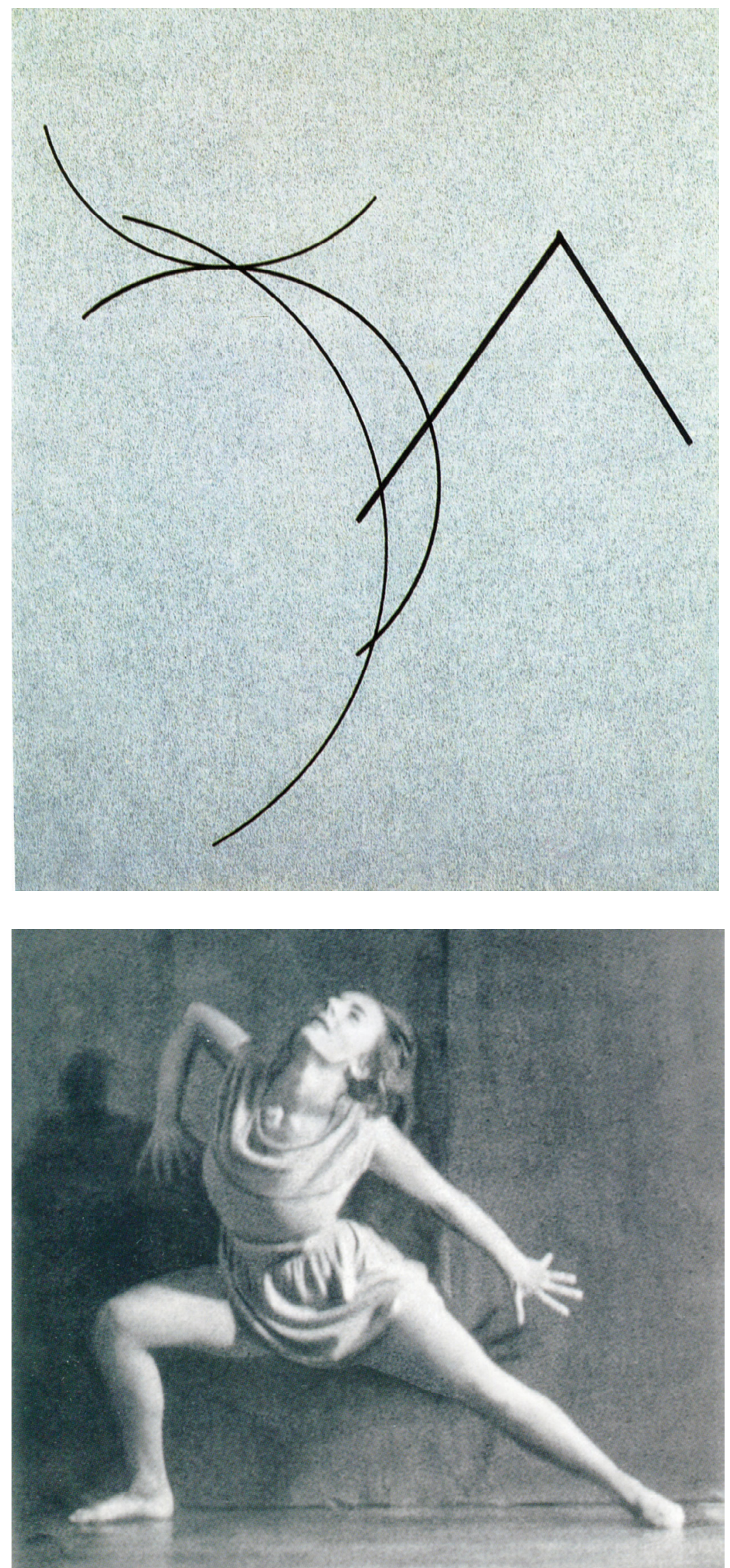
In Munich, Kandinsky met two other Russians, the dancer and artist Aleksandr Sakharov and the composer Thomas de Hartmann. Together they experimented with translation between the languages of painting, music and dance. Choosing from several watercolors, Hartmann picked the one that for him had the clearest musical shape. In the absence of the dancer, he improvised at the piano the music he associated with the watercolor. Afterwards, Sakharov appeared; he listened to the music, danced to it and then looked for the watercolor that had inspired the composer.

Kandinsky was interested in both the synthesis of the arts and the multi-sensorial experience, synaesthesia. As early as 1908, he conceived of an "abstract ballet," The Yellow Sound. In the ballet, coloured geometrical figures were to move on stage to the music composed by the same Hartmann. Kandinsky's attempt to stage the ballet at the Munich Artistic Theatre failed because of the war. In 1928, he succeeded in staging another abstract ballet, to Pictures at an Exhibition by Modest Mussorgsky, at the Friedrich-Theatre in Dessau. In the ballet, there was neither a plot in the usual sense nor themes from Pictures at an Exhibition. Instead colored geometrical figures moved in different directions, towards and away from each other.

In the early 1920s, Kandinsky composed a program for a new research centre, the Institute of Artistic Culture, and he included the study of physical movement and dance in the program. He also suggested examining elementary movements and their combinations, or composition, as a way to arrive at the art of dance. Although Kandinsky left Russia soon thereafter, his close colleagues implemented the program at another new institution, the state founded Russian Academy of Artistic Sciences. In May 1922, Aleksei Alekseevich Sidorov (later the academic secretary of the latter) and Aleksandr Illarionovich Larionov facilitated the opening of the Choreological Laboratory as a centre for dance and movement studies. Sidorov, who had apparently met Kandinsky in Munich, shared his ideas; he himself nurtured a long-term interest in dance. At the end of 1922, Sidorov published a monograph, Modern Dance (Sovremennyj tanec), the first on the subject in the Russian language.

Following Kandinsky, Sidorov regarded dance as an "artistically organized movement" in time and space. Both valued dynamism as opposed to posing, "pure" or abstract movement as opposed to plot and narrative (which the dance

Figs. 1-4 Kandinsky's analytical drawings after the photographs of the dancer Gret Palucca, 1925. Photographed by C. Rudolph, reproduced in Das Kunstblatt, 1926, 10 March.

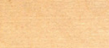

СОВРЕМЕННЫЙ

TA H E Ц

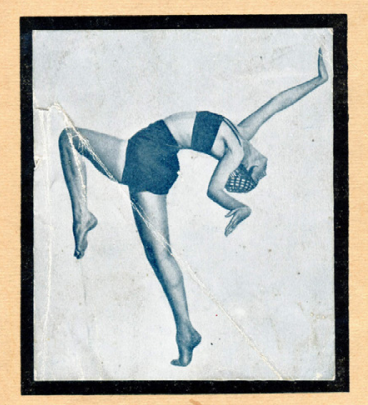

МОсКВА "ПЕРВИНА" МСМХXIII

Fig. 5 The cover of Sidorov's book, Modern Dance. On the cover, Aleksandra Rudovich, dancer and acrobat (who eventually married the avant-garde artist, Vladimir Tatlin). 
historian Liubov Mendeleeva-Blok called "literature"). Sidorov coined the term "choreology," for a new scholarly discipline of dance and movement. Some years later, Rudolph Laban opened his Choreological Institute in Germany. Laban is widely regarded as a founder of modern dance and especially of expressionist dance (among his students were Mary Wigman, Kurt Jooss and Gret Palucca). Together with Sidorov, they shared a preference for the most pure of all movements, the dance of the naked body. Laban in the art colony Monte Verità and Sidorov in the Choreological Laboratory in Moscow both practiced nude dance. Sidorov (who, by contrast with Laban, did not dance himself) explored with his dancers various poses from Ancient Greek sculptures. Even before the Choreological laboratory was founded, he had experimented with hypnotic dance at the Psychoneurological Institute in Moscow.

Following Kandinsky's guidelines, the Choreological Laboratory's programme included breaking dance into elementary movements and analyzing their combinations, or the composition, of dance. Priority was given to dance on stage. The visual effects of different backdrops and framings, different positions of the body in space and various costumes and shoes were compared.

In the spirit of Kandinsky, who was interested in the psychological impact of art elements, we know from Larionov that the laboratory was to study the effect of various dance elements on both the spectator and the dancer. It was also suggested that psycho-physiological experiments should be used to determine the impact of various elements. Continuing Kandinsky's interest in both the synthesis of the arts and synaesthetic perception, the researchers explored correspondences between movement, music and color (particularly the effects of various colors in decoration and costumes for dance performances).

For seven years, between 1922 and 1929, the Laboratory staff took hundreds of photographs of dance, acrobatics and athletic movements. Sidorov, Larionov (from 1923, the official head of the Choreological Laboratory) and several invited choreographers, each devised various sign systems for notating dance.

The Choreological Laboratory organized four exhibitions of "the Art of Movement" showing photographs and other images of dance, movements done when working, and animals in motion. Kandinsky's idea was to bring

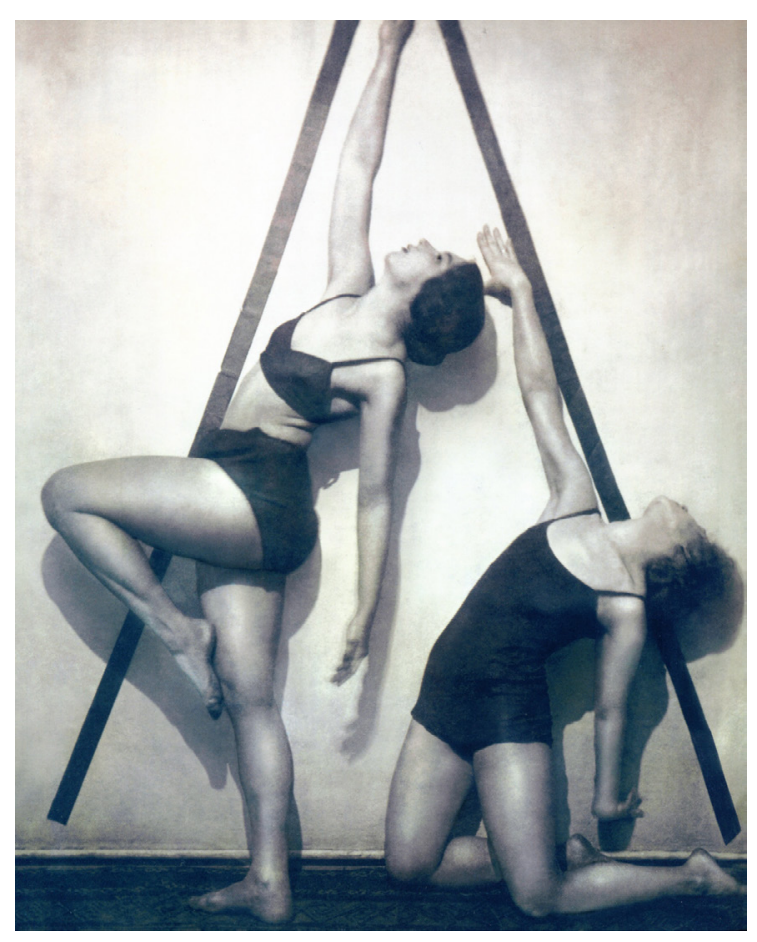

Figs. 6 and 7 Versions of filling in the space. Photographs from the Choreological Laboratory, mid-1920s, reproduced in Nicoletta Misler, $V$ načale bylo telo (In the Beginning Was the Body) (Moscow, Iskusstvo-XXI vek, 2011), pp. 400, 404. 
together all sorts of movements and to theorise about movement as such, "quel tel," as an independent element of art. In 1923, Sidorov and Larionov went so far as to suggest a special discipline of "kinemology," to study movement and its representations in art, photography and film. One may think that Kandinsky would have approved of the project - a project never realized.

\section{SELECTED REFERENCES}

Kandinsky 1921 / 1994: Kandinsky, Wassily, "Report to the First All-Russian Conference of the heads of art departments" (1920), in his Complete Writings on Art (New York: Da Capo, 1994), pp. 473-474.

Kandinsky 1926 / 1994: Kandinsky, Wassily, "Point and Line to Plane" (1926), in his Complete Writings on Art (New York: Da Capo, 1994), pp. 527-699.

Larionov, Aleksandr, "Programma raboty Xoreologičeskoi laboratorii” (Work Programme of the Choreological laboratory), 1923 manuscript in Russian Archive for Literature and Art, Fund 941 (Russian Academy of Artistic Sciences), inventory 17, unit 3, pp. 16-21.

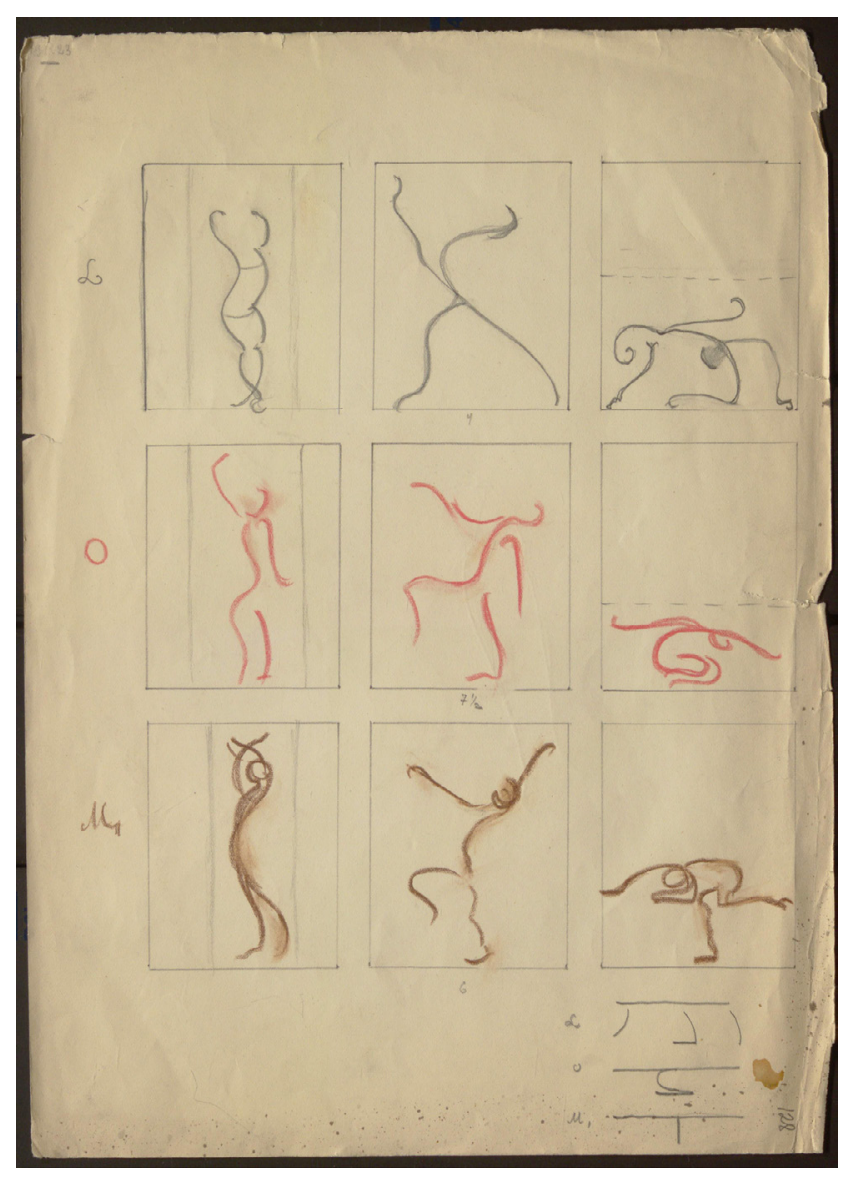

Figs. 8 Aleksei Sidorov, Dance notation, ca 1930. Courtesy of the Manuscript Department of the Russian State Library, Moscow (Fund 776 (Sidorov, A.A.), box 4, unit 20), p. 128. 


\title{
E. ARCHITECTURE
}

\section{KANDINSIKY AND ARCHITECTURE}

Ross Wolfe

\begin{abstract}
This paper explores why Kandinsky is so seldom mentioned in surveys of architectural history. Other abstract painters, for example Mondrian or Malevich, are more often studied when it comes to the connection between painting and building. By looking at Kandinsky's uneasy relationship with constructivism in art, the reason for his absence from histories of architecture becomes clear.
\end{abstract}

Keywords: Architecture. Constructivism. Abstract art.

\section{RESUMO}

Este texto explora as razões de Kandinsky ser raramente citado na historiografia da Arquitetura. Outros pintores abstratos, como por exemplo Mondrian ou Malevich, são estudados com mais frequência quando da conexão entre pintura e construção. Por meio do exame da inquieta relação de Kandinsky com o construtivismo em Arte, tais razões de sua ausência na historiografia da Arquitetura se tornam claras.

Palavras-chave: Arquitetura. Construtivismo. Arte Abstrata.

Wassily Kandinsky is not often mentioned in surveys of architectural history. If he is at all, it is usually only in passing, in connection with his time spent teaching at the Bauhaus. Even then, this is because the school became so well known for its contributions to design, whereas Kandinsky was just one of the major visual artists on its staff. Paul Klee, Johannes Itten, and László MoholyNagy taught there as well. Other abstractionists, for example Kazimir Malevich or Piet Mondrian, tend to receive more ink when it comes to the relationship between painting and building. Given the influence of the former upon the latter in the twentieth century, especially as upheld by the historian Siegfried Giedion, this is perhaps a bit surprising.

Maybe it is due to the lack of overt tectonic elements in Kandinsky's art. Unlike Malevich, whose model Архитектоны simulated the volumes of built 
structures, or Mondrian, who corresponded at length with architects such as Gerrit Rietveld and JJP Oud, Kandinsky never explored the implications of his work for architecture nor inspired contemporaries to do so. He was nevertheless held in high regard by figures like Walter Gropius and Ludwig Mies van der Rohe, the first and third directors of the Bauhaus, respectively. Gropius had invited him to come teach in Weimar, sending a handwritten note via the Bolshevik Karl Radek in Moscow. Similarly, Mies told his student Howard Dearstyne that he considered Kandinsky "a highly intelligent man" [,ein hochintelligenter Mensch “]. Dearstyne himself recalled years later:

Kandinsky was a profound student of color, who realized that if it were to be applied to architecture, its physical characteristics had to be understood and the techniques of its application mastered. Being a painter, knowing the psychological potential of that particular medium, he was aware of what color could do to architecture.

According to his friend and biographer, the critic Will Grohmann, an architectural excursus was one of Kandinsky's longstanding ambitions. "To work in space - or with architecture - is an old dream of mine which I hoped to realize when I went to the Bauhaus, but unfortunately have not as yet," he wrote to Grohmann in 1924. "So far, my only large-scale effort was painting the reception room for a museum of art commissioned by the Juryfreie two years ago." Previously, Kandinsky had written in his 1921 program for the Institute of Artistic Culture [Инхук] in Moscow that "as far as architecture is concerned, this art possesses a condition that distinguishes it from either painting and sculpture: its applied aspect, the necessity to adapt a building to the existence of people inside it, so that inevitably abstract form is left out."

In that same document, Kandinsky nevertheless affirmed: "When the cultural renaissance occurs, architecture will be renewed, at long last heeding the resonant voice of the new art." Clearly, he was optimistic about the future of architecture. Not long after arriving in Weimar, Kandinsky sketched an outline for his lecture on form in which he highlighted its relation to painting and sculpture. "Building (architecture) can be nothing if not colored (painting), able at any moment to fuse divisions of space (sculpture)... sucking streams of people through open doors in accordance with a strict schema," he wrote. Undoubtedly, one of the main reasons teaching at the Bauhaus appealed to Kandinsky was its commitment to synthetic collaboration, as he put it in a 1922 exhibition catalogue: "Today we stand under the sign of synthesis. Roads hitherto traveled separately have now become one road, traveled all together, like it or not." 
One of the more controversial claims regarding Kandinsky's oeuvre is that he ended up adopting constructivist forms, despite his repeated polemics against their cold, almost mathematical precision. He dated his Première abstraction to about 1910, a watercolor marked by conical shapes and sudden splotches of color. Some of his other watercolors from this period were simple preparatory studies, working out beforehand how the component parts of his oil paintings would be arranged. Kandinsky thus called his more consciously produced canvases "compositions," while more spontaneous pieces were filed under "improvisations." For the most part, however, even his most deliberate works from the Blaue Reiter years were expressionistic, featuring jagged lines and dramatic arcs of light. They give a sense of pure immediacy, as if they bubbled up out of the depths of Kandinsky's soul, the products of unfiltered intuition.

After he returned from Russia in 1921, Kandinsky began to incorporate more geometric shapes in his sketches and paintings. Many have speculated that this was an effect of constructivism, a young movement pioneered by Vladimir Tatlin and Aleksandr Rodchenko, rubbing off on the older painter. Grohmann was skeptical of such interpretations, though. "It has often been suggested that Kandinsky transitioned to his later, colder style while in Moscow, and did so under the sway of constructivism," wrote Grohmann. "But there were strictly geometric elements in Kandinsky's works even during the Munich period, and moreover, the works of his Russian years down to 1921 reveal no constructivist influence whatsoever. Subsequently during his tenure at the Bauhaus, he attested that constructivism was alien to him... His paintings after 1922 are referred to as constructivist only on account of their austere structure and unmistakably geometric forms, not their aesthetic spirit. Constructivists had no ties with him either in Germany or in Russia, and tended to regard him as an opponent... Kandinsky largely went his own way."

Evidence of the constructivists' hostility can be seen in some of the critical barbs they directed at Kandinsky's work. Władysław Strzemiński, the Polish constructivist, reviewed an exhibition of Russian art in 1922, dismissively remarking: "One ought to see Kandinsky as the last representative of a dying impressionism, as an artist mistakenly included in the new art." Likewise Adolf Behne, an avant-garde critic, observed: "In no sense is Kandinsky's abstract canvas the last word in Russian painting." At any rather, such comments did not pass unnoticed. He explicitly instructed gallerists in 1928 not to refer to him as a constructivist in their catalogues. In late 1931, Kandinsky wrote:

Artists calling themselves "pure constructivists" have made various attempts to construct on a purely materialistic basis, 
trying to eliminate "out-of-date" intuition so as to serve our present, "rational" age by means adapted to it. They have never been able to establish a clear-cut formula that corresponds to every proportion of a painting, obliged either to paint poor paintings or correct their reason using "out-of-date" intuition.

Kandinsky's ire did not end there. Later, for a 1935 issue of Christian Zervos' periodical Cahiers d'Art, he wrote:

Regarding misunderstandings and harmful "mix-ups": The constructivists state that emotions received by the artist from outside are not only useless, but must be fought against. According to these artists, they are "remnants of bourgeois sentimentality" which must be replaced by the pure intention of the mechanical process. Constructivists build "calculated constructions" to do away with feeling, not only within themselves, but also within the beholder, to liberate him from psychology and turn him into a "man of the present."

In truth, these artists are mechanics (spiritually limited children of "our mechanistic age"). Yet they [e.g., Tatlin] produce machines deprived of movement, engines that do not move, planes that do not fly. Most constructivists [e.g., Rodchenko] soon stopped painting altogether. One of them [Lissitzky] declared that painting is merely a bridge which must be crossed to reach architecture. He forgot that there are many great architects [Le Corbusier] of the extreme avant-garde who have not ceased to paint at the same time.

The tacit allusions Kandinsky made in this passage are here placed inside brackets for easy reference, but are obvious enough. Because the example/ counterexample of Lissitzky/Le Corbusier is the most germane to present purposes, it will be dealt with in what follows. Each of these figures had been an accomplished painter.

Lissitzky was a student of Malevich and a supporter of suprematism in art. He famously declared in the early 1920 s that his Proun series of canvases were stations on the way to architecture. Indeed, he felt that the art of painting had been definitively superseded by the art of building, and was now a part of history. Although Lissitzky never managed to get anything built, several of his proposals came to be quite well known (like the Wolkenbügel slab, meant 
for Moscow). Far more successful was Le Corbusier, who had originally been trained as an architect but started dabbling in postcubist painting after he met Amédée Ozenfant in 1917. Together they innovated purism, a flattened style depicting mass-produced objects of everyday life. Corbusier returned to architecture in the 1920s, launching a legendary career that spanned four decades on multiple continents, but he continued to paint every morning after breakfast.

Kandinsky had a point, it would seem. Why then did he never make a transition to architecture? Once again, his painterly abstractions did not lend themselves well to architectural cognates. Still, this might have been a function of the age in which Kandinsky worked. Emulating the biomorphic curves of his later paintings would have been impossible in the first half of the twentieth century. Now with computer aided design, irregular dips and surfaces can be more readily fabricated. 


\title{
2. THE SPIRITUAL IN ART AND ARCHITECTURE: \\ NOTES FOR A NEW CONTEXT \\ Elijah Williams
}

\begin{abstract}
Wassily Kandinsky's writing in Concerning the Spiritual in Art (Dover, 1977), are seen through their relationship to Architecture. Questions about the origins of contemporary Architectural intention, duty and function are raised through pairings with quotations from Kandinsky.
\end{abstract}

Keywords: Architecture. Function. Kandinsky. Representation.

\section{RESUMO}

O livro Sobre o Espiritual na Arte (Dover,1977), de Wassily Kandinsky, será aqui discutido em relação à Arquitetura. Serão colocadas questions acerca das origens da função, dever e intencionalidade da Arquitetura contemporânea por meio de trechos da obra de Kandinsky.

Palavras-chave: Arquitetura. Função. Kandinsky. Representação.

$\odot$

\section{INTRODUCTION}

Recently, making notes in my copy of Kandinsky's Concerning the Spiritual in Art (Dover, 1977), it struck me how much of Kandinsky's thinking, theory and writing have manifested themselves in the world of Architectural discourse. From the start, I found that some of Kandinsky's Introduction (see pp. 4-5), as well as his "The Movement of the Triangle" (see pp. 8-9) have strong parallels to architecture discourse without reducing any element of either to actual buildings or paintings.

The complete book is full of potent quotations, and many of my dozens and dozens of notes could have been expanded into essays. But already at these two key points - Introduction and opening chapter - the book speaks directly to the duty and function of the built environment, so I chose these two as starting places:

Often, many years after his body has vanished from the earth, men try by every means to recreate this body in marble, iron, bronze or stone on an enormous scale.

Wassily Kandinsky, "Introduction” 
The most literal manifestation of this "recreation" is in the form of the built environment, where the legacy of a single person or a family can be prolonged through the construction of a work of Architecture. These objects, sometimes buildings and sometimes not, have the capability to create a physical narrative trail that will long outlast any individual human or even generational family. This ancient practice, employed by nobility and the religious devout, is an indicator that the spaces and objects that surround us are not simple in purpose or function, that their origin may be a set of twisted extremes. Memorials to great love rival those that are tributes to war and greed. For every Holy Mosque there is a skyscraper with gold lettering, twelve feet tall, emblazoned across it. We are surrounded by physical reminders that it is a recreation of self that these builders are looking to achieve. These acts, of constructing these monuments, signify their importance as legacy markers for human activity.

The materials listed - Marble, Iron, Bronze and Stone - have a chronology to them, suggesting correctly that these symbols of power date back long before the use of aluminum ducts and plastic flashing in skyscrapers, to a time when building a monument to power meant using a scale unimaginable.

What would the world around us look like if we were without the desire to build tributes to our own power? Would the line between our art and our architecture be more severe? We could dramatically identify Architecture as that which serves the practical functioning of life, and art as everything else. This feels short, because we know there is something more involved, something that concerns the spiritual in Architecture, which we have a harder time pinning down. Architecture and the objects it produces are often regarded in the public as if they are not also part of the world where things can have simple origins. Or as if a work of Architecture could have an ulterior motive or be a monument to the greatness of humans.

Objects at this scale sometimes take on purely representational form, such as sculptures of gods or animals or men, but most often are disguised as Architecture. Hidden in the endless mirrored windows of corporate business parks and the stale stairways of skyscrapers is another form of representation that is driven by ego and the acts of seizing power. Looking at a building alone doesn't reveal the whole story of why it exists; instead we must tread into the murky waters of Architecture to find out who built it, why and what they were hoping to compensate for.

[Art] seeks her substance in hard realities because she knows of nothing nobler. Objects, the reproduction of which is considered her sole aim, remain monotonously the same. The question "what?" disappears from art; only the question "how?" remains. 
By what method are these material objects to be reproduced? The word becomes a creed.

This "what?" will no longer be the material, objective "what" of the former period, but the internal truth of art, the soul with which body (i.e. the "how") can never be healthy, whether in individual or in a whole people.

Wassily Kandinsky, "The Movement of the Triangle"

One key element in the field of Architecture, both in academia and in the public, is the relationship between architects and engineers. The relationship is not straightforward, with architects proposing a giant sphere and the engineer saying it can only work as a square. Often it is the engineer who has a new technology or methodology that is primed to revolutionize the scope of what the architect can think. While this may seem to be a purely bureaucratic dynamic, it represents how the relationship between "why" and "how" can become distorted in its aspirations.

The question of why humans continue to build buildings, long past pure necessity, is commonly addressed through statements about creating transformative and impactful spaces that complement the human condition or, at best, challenge the nature of our existence as we currently occupy it. But in tangible reality, what we see is a field driven by best-practice construction and short-term memory, restricted not by the depths of the imagination but by the pockets of investors.

The "why" becomes wrapped up in the want to construct monuments and give metaphorical weight to concepts of stability in the form of banks made of stone, or technical complexity to the world of scientific research with climate controlling multi-layered façade windows. Reasoning, or motive, can come in such a variety of forms that it is no longer straightforward, these buildings are no longer representational manifestations of the ideas behind them, but instead they become surreal billion-dollar metaphors. This is the role of Architecture, the muddy gray area between art and engineering, where there is plenty of "why", but no one asks, and a little "how" ends up going a long way. These ideas are not in any way new: they point out how related the work of the "why" is related to the work of the "how".

While the architectural concept of materiality deepens the relationship between what something looks like and what it is made of, the "how" in this case is very literal. To say a building is made of brick implies that it is a composite object, amassed from a set of smaller objects called bricks. We have no issue with describing it as a brick building. When we are describing the 
construction method we are describing the building, not the Architecture. Buildings are made of bricks. Architecture is made up of complex systems of objects, including bricks but also including things like the absence of brick and, the ever ephemeral, light.

There is an ever-changing web of progressive, carbon footprint-reducing and visually spectacular building technology systems (solar panel roofs, integrated grey water collection systems, computerized shading, etc.) that make up what we call contemporary architecture. Which is to say that innovations in the world of building technologies drive much of the "why" buildings exist. The line between where the systems, the construction method and the architecture itself exist becomes so blurry that we no longer have objective truths about where our Architecture starts, and are without the proper language to describe what has grown to occupy our built environment.

Construction and innovation in fabrication give a purpose to the creation of entire buildings. The classification of Architecture as a scientific-art reveals that it is a field that may not actually be interested in what things look like past the superficial idea of bringing an object into existence. Which is to say that, in Kandinsky's terms, the "why" has turned so far into a "how" as to be confused for a "why" again. 


\section{F. FURTHER PERSPECTIVES}

\section{ON KANDINSKY: LISSA TYLER RENAUD INTERVIEWS}

\section{ART HISTORIAN PETER SELZ}

Lissa Tyler Renaud

\section{ABSTRACT}

Eminent art historian, Peter Selz, now 99 years old, offers his perspectives on and historic first-hand experiences of Kandinsky's work.

Keywords: Kandinsky. Peter Selz. Gabriele Munter. Guggenheim.

\section{RESUMO}

O eminente historiador da Arte, Peter Selz, em seus 99 anos, oferece suas perspectivas e primeiros contatos com a obra de Kandinsky.

Palavras-chave: Kandinsky. Peter Selz. Gabriele Munter. Guggenheim.

On April 8, 2018, eminent art historian Peter Selz and I met at Berkeley's legendary restaurant, Le Bateau Ivre, a plaster and stone house built in 1898, when Kandinsky was 32. There, Dr. Selz reminisced as I interviewed him over dinner, on subjects formal and informal pertaining to Kandinsky. Leaving our meeting, he said that as a child growing up in Munich, he was very aware of where Kandinsky lived, not far from his own home. Dr. Selz is a few months shy of 100 years old, so his critical responses and first-person accounts are of special interest.

\section{Has your thinking about Kandinsky changed over the years?}

No, I knew from the very beginning, from the early work, what a great artist he was. And I don't think my opinion has changed that much. You know, he stands out as this giant, and all this stuff has been written, that other people did non-objective paintings at the same time or earlier, it doesn't make a damn

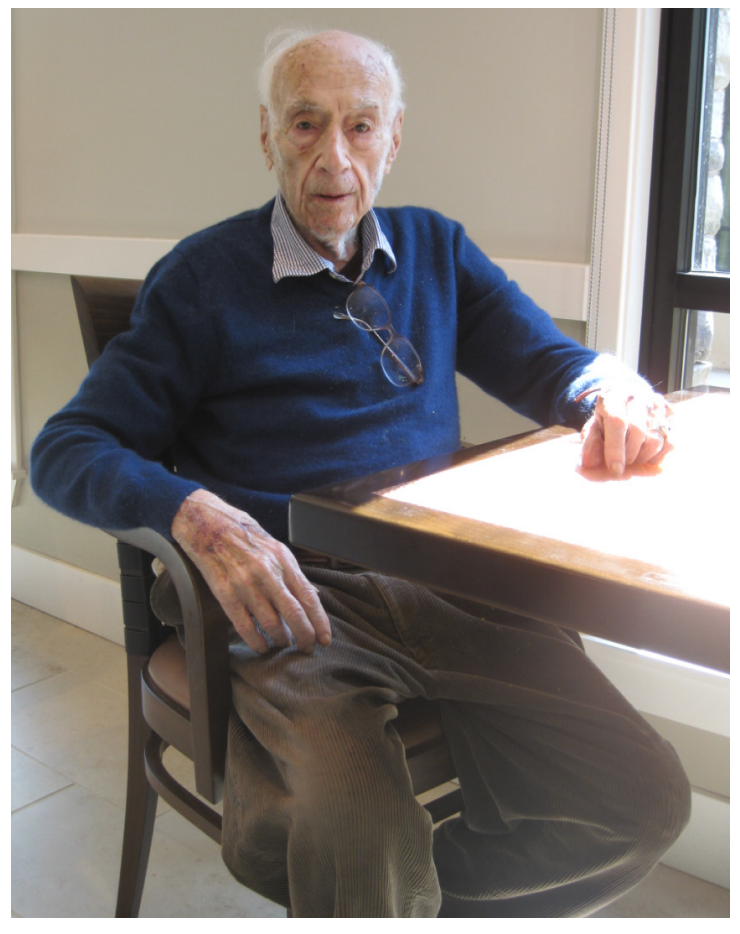
bit of difference. The important thing is how good his paintings were. And they look so incredibly good. And when I go back and see some exhibited at
Fig. I Photo by the author, Aug. 10, 2018 
the Guggenheim, I mean, they are just such wonderful paintings, and they don't look like anybody else's.

\section{Who do you think is the heir to Kandinsky's painting? What painters have carried on Kandinsky's work?}

My god! In a way, all the Abstract Expressionists. I mean, they all looked at Kandinsky, I know that. I mean, when I talked to the artists in New York, whether it was de Kooning, or Mark Rothko, they were very much aware especially de Kooning - they were very much aware of Kandinsky. And, you know, Abstract Expressionist art, non-figurative art, all owes a major, major debt to Kandinsky. And of course, in New York, with all the Kandinskys at the Guggenheim, they were very familiar with the work. The people I knew, they talked about Kandinsky - Kandinsky was very, very well known by then, because he had all the Guggenheim paintings. They weren't always shown, but they were there.

And I remember when I first saw the Kandinskys at the Guggenheim they had a temporary space, on E. 54th Street [it opened in 1939 -ed.], and there was Hilla Rebay, the woman who ran the Guggenheim - and they were hung there on very thick, gray carpets, with low light, paintings hung very low. And there was great silence in these spaces, and she would say, something to the effect that: as far as non-objective, abstract expressionist painting go, Kandinsky was the prophet, was the hero. Kandinsky and Bauer. She bought a huge numbers of Rudolf Bauer paintings - they don't look so bad now. They look pretty good. You know, he was glorified, as far as anybody knew... Hilla Rebay — she had an affair both with Guggenheim and with Bauer — and she got the Guggenheim money to buy the Bauers. Anyway, Kandinsky was well known because of that: the New York painters, they saw his work, these paintings, at the temporary Guggenheim. They didn't talk all that much about Kandinsky, but they were clearly aware of his work and knew it well. I remember, I knew Rothko pretty well, and he spoke with great admiration about Kandinsky.

\section{You met Nina Kandinsky.}

I originally met Nina in 1950, when I was on a Fulbright to work on German Expressionism. I was in Paris, and naturally, I sought out Nina. And I spent quite a bit of time... I saw Nina three or four times, up in Neuilly, where they lived. And I don't remember too much about that. What I do remember is, some years later, when there was a big Kandinsky retrospective at the Guggenheim. And the two guests of honor were [Hans] Roethel, from the Kandinsky museum in Münich, and Nina. And Tom Messen - he was director of the museum - 
I knew him very well... He said: keep Nina away from Roethel — Roethel was the director of the Kandinsky Museum - so it was a big thing. And I talked to Nina, keeping her away from Roethel. And she told me all kinds of unbelievable things, like - I think she was a little bit gaga at that point — she said, "All these so-called Kandinsky paintings, in the museum in Münich, are not... they are done by Gabriele Münter" - because if they had been done by Kandinsky himself, she would own them! So I said, "Mrs. Kandinsky - you didn't know him at that time." [Laughing.] So, she disregarded that.

Oh, there's one more story about Nina. She owned at that point quite a few of his late paintings. So I asked her, "What are you going to do with these paintings?" And she replied, "I will keep them until the Tsar is back, and then I will give them to Russia." Put that down [referring to my note-taking, laughing] "I will keep them until the Tsar is back, and then I will give them to Russia." Put that down [laughing]! I don't think she was all that clear-minded at that point. Telling me these crazy stories, like the ones you've written down. I mean, how can you pay attention to that? It was nuts.

I spent time with her and with Münter.

\section{Tell me about Gabriele Münter.}

Oh, I liked Gabriele Münter a lot. I spent a couple of hours one afternoon with Gabriele Münter, at her house, at Münter's house, up in the Alps, and I really enjoyed that. Everything very simple, coffee, good conversation. Her husband was there, too. They lived in Murnau. And Murnau was in the foothills of the Alps. About 60 or 70 kilometers south of Munich. A lovely village, in the foothills. And Kandinsky spent a lot of time there, in Murnau. She was married at that time, and she lived there - it was maybe 1957 or ' 58 . And I had a really good time; she was a good woman.

\section{What did you talk about?}

We talked about Kandinsky. There was nothing else! And what she said about him I don't remember. But they had a relationship that lasted quite a few years. They were very, very close. They lived together, more or less, all those years.

\section{In her photos she often looks a little... dour. And in her letters...}

I found her very, very agreeable.

\section{That's nice to hear.}

She was married afterwards. 


\section{Yes, to Johannes Eichner, an art historian.}

And she was a good artist! Oh, she was a very good artist. And a lot of her paintings are in the Kandinsky Museum.

Do you think Kandinsky was influenced by Münter? They influenced each other?

Well, they lived together, and they probably influenced each other - a very close relationship: they were both painters, and their friendship... They influenced each other. I can't identify how. She was younger, and in a way she was a student as well as his lady friend. She was both.

\section{Before we met today, you mentioned Kandinsky and religion. Tell me about} that.

Well, OK. When I first looked at the Kandinskys, these paintings, these wonderful abstract expressionist paintings - in those days, no one talked about their spiritual quality. And this was overlooked, and this cannot be emphasized too much. I mean, he really believed that art was a matter of the spirit. I actually think he was a religious man...

I often feel people over-emphasize his theosophical interest. I mean, it was only early in his life, in his career, yes?

Yes.

I mean, he didn't talk about theosophy throughout his Bauhaus period, his Paris period.

That's right, right. It was early. I mean, he wrote The Spiritual in Art - what year was that? 1912? Before the war. Before the Bauhaus. I think after the war, the spiritual was less important. Yes, I think so. He looked at other things at the Bauhaus. And, you know, he was the great master at the Bauhaus, from beginning to end. Other Bauhaus artists came and went, but he was there until the very, very end. By that time, he'd achieved great international fame.

[Taking a bite of his food] This is very good.

Can you say more about his Bauhaus period? After his second Russian period, when he went back, and the Revolution - then we have the Bauhaus, and then the French period, the last years.

At the Bauhaus, his work changed from the free-form expressionism to a more severe, increasingly geometric painting. Which was very much in keeping with the Bauhaus ideas. I mean, there he was, working in this 
geometric, Gropius building - it may have had an impact, I don't know. Working with other artists... In general, things moved from the more freeform expressionism to a more geometric abstraction. Not just with Kandinsky, but in German art in general. And he was very much part of this. Maybe what he did had a great affect on what other people did - he was really seen as a master.

What do you know about Schoenberg's falling out with him — when Schoenberg accused him of being anti-Semitic?

Now, as far as I know, Gropius considered appointing Arnold Schoenberg to the faculty of the Bauhaus. And I believe that Schoenberg felt that Nina Kandinsky was anti-Semitic, and that, in a way, kept him from accepting. I'm not sure about this, but that's what I've read. It could be true.

I read that it was [Gropius's wife] Alma Mahler who started the rumor. And that was embarrassing for Gropius.

I think that's right. Yes, this is a rumor that goes back to Alma Mahler. That may or may not be true.

On a more personal note: tell me one thing you like about Kandinsky's work, and one thing you don't like, or think is not successful.

I personally like the free-form abstract paintings the most. The pre-war paintings. And there's nothing I don't like. I like the late paintings - many people don't like his late paintings. But I understand the late paintings, and I like the late paintings very much. I mean, they don't, obviously, affect me emotionally as the more emotional earlier paintings. My emotional response to the emotional quality of his 1915 paintings... But I respect the Bauhaus and the Paris pictures, very much.

Yes, I do, too; I love them. When you were in Neuilly, did you see Kandinsky's studio?

Lissa, he didn't even have a studio. He painted in their apartment in Neuilly, as far as I know. There was a room - I'm not totally sure now, but I seem to remember - but I saw Nina several times in their apartment in Neuilly, and I think this is where he painted. I'm pretty sure.

\section{What was it like?}

I don't remember, but I'm sure it was all neat and clean. It was not what you'd think an artist's studio would look like. And I'm almost certainly sure that he 
painted with his necktie on. You know, that's what his late paintings look like: they're very formal.

I think he was pretty isolated in Paris. I think he had an affect on what was going on, but he was not really part of the Paris situation.

Yes, partly because of his painting life, and also [for personal reasons].

I think that's quite possible.

\section{Is there anything you feel the scholars have misunderstood about Kandinsky?}

Well, I don't know if people really realize what an important master he was. Maybe they do know - but I don't know... art history gets re-written all the time. [Silence.]

I would have liked to know him.

He was kind of a private person.

Yes, a different kind. 


\title{
2. KANDINSIKY AND THE TOTALITARIAN STATE
}

Zarina Zabrisky

\begin{abstract}
In the 1920 and '30s, Wassily Kandinsky, labeled "ideologically decadent" and "lackey of the bourgeoisie" in the USSR, and a "degenerate artist" from a "hotbed of Bolshevism" in Nazi Germany, emigrated twice to escape death. His legacy lives on as totalitarian regimes seek to regain power.
\end{abstract}

Keywords: Kandinsky. Degenerate Art. Abstract Art.

\section{RESUMO}

Nas décadas de 20 e 30 do século passado, Wassily Kandinsky, classificado como 'decadente'ou 'lacaio da burguesia'na antiga União Soviética, ou como um 'artista degenerado' de um 'viveiro do Bolchevismo' na Alemanha nazista, teve de migrar duas veze para escapar da morte. Seu legado vive tanto como regimes totalitários buscam recuperar seu prestígio.

Palavras-chave: Kandinsky. Arte Degenerada. Arte Abstrata.

○

\section{DEGENERATE ART}

The Nazi German exhibition, Entartete Kunst, widely known as Degenerate Art, was organized by the Third Reich in 1937 in Munich. The National Socialists' attack on modern art, it showcased 650 out of 16,000 works of art confiscated from the museums and labeled "un-German," "insult to German motherhood," "insanity room" and "Nature as seen by sick minds." The artists were fired, banned from work and most went into exile. Many paintings were burnt after the show. Hired actors loudly criticized the art in the galleries. This show stayed open for four months and was attended by two million visitors, including Hitler himself. For Hitler, a failed artist whose work did not receive any recognition or attention, "art was, and had to be, a mirror in which the reflection shows the discernible if idealistically transformed human material, and such art must relate to and be governed by the requirements of the struggle of the higher race against the lower and not by any suggestion that the creative process was the result of "inner necessity." (Catalogue, London 1938, Defending 'Degenerate' Art: Mit Kandinsky, Liebermann und Noldge gegen Hitler by Lucy Wasensteiner, Martin Faass.) 


\section{KANDINSKY}

The organizers of Degenerate Art mistook Wassily Kandinsky for a member of the Dada movement and placed the enlarged details of his three Compositions, confiscated during a raid on the Bauhaus art school, on the "Dada wall" along with the art of Paul Klee. Considering that in 1933 Hitler remarked that "sixty years ago an exhibition of so-called Dadaistic 'experience' would have seemed simply impossible, and its organizers would have ended up in the madhouse," this was not just an error. It could be a life sentence. The three Compositions were destroyed.

\section{BAUHAUS}

Degenerate Art featured works by several former professors of the Bauhaus, an experimental art school located in Dessau after 1925. Kandinsky had taught at the Bauhaus since 1922, after his return to Germany from the Soviet Union where the Bolsheviks had labeled modernist and abstract art as "decadent" and Kandinsky himself as the "lackey of the bourgeoisie." Ironically, the Nazis proclaimed the Bauhaus "a hotbed of Bolshevism in culture" and closed it in 1933. "Paul SchultzeNaumburg was the architect that they sent into the school to re-establish pure German art instead of the 'cosmopolitan rubbish' the Bauhaus artists were doing. He described Bauhaus furniture as Kisten, or boxes..."(https://germanculture. com.ua/german-facts/nazi-and-bauhaus-school/.)

\section{"THE GREAT GERMAN ART EXHIBITION"}

At the same time the Degenerate Art exhibit was running in the city of Munich, the Third Reich opened there the Great German Art Exhibition, featuring work approved by the Ministry of Propaganda and Public Enlightenment.

The Nazi movement attracted many who had a grudge against modern art. There were daydreaming racist philosophers, embittered know-nothings, provincials who seized the opportunity to direct their spite against those engaged in activities they could not understand, small-town bigshots and big-town smallshots. Some of the leading party members took pride in what they regarded as their artistic inclinations and were prepared to speak out on the subject of art and artists. Herman Goering was a voracious collector of art; Josef Goebbels was a failed novelist and playwright (his novel Michael: A German Fate in Diary Form is a true literary curiosity): and even the peddler of pornography and obscenities, the corrupt publisher of the infamous Der Sturmer 
(The Stormer), Julius Streicher, attempted the writing of poetry and the painting of watercolors; Alfred Rosenberg, the self-styled philosopher, whose well-known if largely unread The Myth of the Twentieth Century was devoted in great part to a consideration of art and its relationship to society, had in the late nineteentwenties organized the Combat League for German Culture, a collection of wooly-minded activists. (Catalogue, London 1938, Defending 'Degenerate' Art: Mit Kandinsky, Liebermann und Noldge gegen Hitler by Lucy Wasensteiner, Martin Faass.)

The Nazi artists turned to Hellenistic and Nordic visuals for inspiration. They used symbols and imagery that reinforced the myth of "Arian superiority," and promoted youthfulness, health, fertility and purity, such as Hitler Youth Drummer by Anni Spetzler-Proschwitz, displayed at the show in 1939.

Sculptor Arno Breker, who created works such as Prometheus, an oversized sculpture of an Arian male, all sinewy muscles, installed in the garden of the Reich Ministry of Public Enlightenment and Propaganda, eventually joined the Nazi Party in 1937 and became an official state sculptor. Nazi-sympathizing organizations, such as the Military League for German Culture, established in 1928, promoted the idea of 'pure' German culture. The ethnic superiority of Nordic people and fear of Jewish and foreign influences, including "Negro" jazz, became the predominant themes in the art of the Third Reich. Hitler and Mussolini attended the exhibit. It became an annual tradition.

\section{LONDON — TWENTIETH CENTURY GERMAN ART}

From June to August of 1938, exactly one year after Degenerate Art, an exhibition Twentieth Century German Art was organized in central London to challenge the Degenerate Art exhibit in Munich. By 1937, the Nazis had started to confiscate the art from Jewish art collectors, using the label "degenerate" art as justification. Many artists, as well as collectors and dealers, had escaped Nazi Germany and Austria. They sent art to the show, which showcased 300 paintings and sculptures from 90 private collections. Sixty-four artists participated, including Kandinsky, who donated at least two works for the show. All in all, thirteen works by Kandinsky were on display in TwentiethCentury German Art.

"This was the largest international response to the National Socialist campaign against 'degenerate' art, and it remains the largest display of twentieth-century German art ever mounted in Britain," according to the 
curators of the exhibit London 1938: Defending 'Degenerate' German Art, which commemorated the $80^{\text {th }}$ anniversary of the London show. "Much of this art is now in official disfavour in the country of its origin," read the flyer that featured Franz Marc's Blue Horses.

The show was a great success. The opening attracted over one thousand people. By mid-August, an estimated 12,000 people had visited the exhibit and it was extended three times. "Women were kept waiting in the rain, staircases and galleries were difficult to move in," reported the London press. "Because their work shows the horrors of war, because it conflicts with Hitler's "artistic ideas" (he is an amateur painter), most of the last century they have been forbidden to exhibit in their own country," wrote another newspaper.

\section{THE THIRD REICH'S REACTION TO LONDON EXHIBITION}

As noted in the informational materials of the London 1938: Defending 'Degenerate' German Art exhibition:

In Nazi Germany, Twentieth Century German Art prompted a furious reaction. Adolf Hitler spoke out against the show at the opening of the second annual Great German Art Exhibition in Munich in 1939... and various angry reports followed in the Nazi-controlled German press. For example, the Voklischer Beobachter characterized it as 'Judaism and Moscow' presenting lies to the 'politically clueless English.'

"The Progress of Bolshevik Art - Degenerate Exhibition in London - half of them, of course, Jews and Emigrants," read a headline from the German press covering the London exhibit.

\section{“GREAT GERMAN ART" AND "BOLSHEVIK ART"}

In another ironic twist, the real "Bolshevik Art" was practically identical to the "Great German art." The Soviet official style was called "socialist realism," a representational art style that was class-based, widely accessible, and comprehensible to the masses.

Kandinsky, who had to return to his native Russia in 1914 from Germany after the beginning of World War I and got inspired by the experimental nature of pre-revolutionary and early Bolshevik Russia, left it for good in 1921, unable to create under the dictated mandates of the Communist party leaders.

The Soviets, like the Nazis, very quickly knew to allow only the art and culture that served the state and fit into the official ideology of the ruling party.

The art, as the regime's tool, promoted the stereotypes of loyal citizens united by the ideals of the utopian future in the Soviet Union (blood and soil in the Third Reich); sacrifice of an individual life for the well-being of the nation and 
world proletariat in the USSR (the Arian race in the Third Reich); the great destiny of the chosen class (race in the Third Reich); muscular masculinity; fertile femininity; sanctity of motherhood; athletic vitality; military power.

\section{ART, PROPAGANDA AND THE TOTALITARIAN STATE}

Fatherland and Motherland, traditional gender role distribution, racial or class purity, unity in the name of race or class - the vocabulary of a totalitarian state and authoritarian dictators is the same anywhere on Earth, regardless of the era.

In the 1930s, both the Nazis and the Soviets ideologues put culture in the center of propaganda work. As early as 1933, Hitler and the Reich Minister for Public Enlightenment and Propaganda, Josef Goebbels, signed a law on establishing the Reich Chambers of Literature, Press, Broadcasting, Theater, Music, and Visual Art. Thus, the Ministry of Public Enlightenment and Propaganda started to control all spheres of culture. In 1932, the Union of Artists replaced all art schools, groups, circles and societies in the USSR. The Soviets also had a Ministry of Culture that reported directly to the Kremlin and the censorship system that erased any voices outside of the party line. Stalin, like Hitler, was a failed artist; he started by writing poetry and "curated" the poets and writers personally.

In 1933, just as the Nazis closed the Bauhaus, the Soviets labeled Kazimir Malevich's "Black Square" as the product of the "rotting" bourgeois art, and socialist realism held a monopoly on the cultural arena in the USSR.

While the messages of the Soviets and Nazis differed - the superiority of the 'Aryan race' vs. the hegemony of the proletarian class - the essence was the same. National Socialist and Soviet socialist realist aesthetics reflected the ideology of the totalitarian state intolerant to the liberal democracy individuation and freedom pioneered by the founder of modern art, Wassily Kandinsky.

For the break through the representational barrier into pure abstraction presents a danger to oppressive regimes. The rights of thought and imagination undermine the crowd mentality, military discipline and the blind obedience required of a loyal citizen of a fascist state. The chaos of colors is unacceptable. A strict order must rule. The departure from a utilitarian approach - the fascists' doctrines and dogmas - is punished.

Nowadays, in Putin's Russia, the same playbook is used. In 2015, the secret police raided an exhibition of a group called Blue Rider, inspired by the name of Kandinsky's own group (1911-1914). The artists dared to challenge the nationalist fervor of the Victory Day celebration and depicted the war in a horrifying way, "insulting patriotic feeling." The art was confiscated. In the best tradition of the Third Reich, the artists were beaten up and detained. 


\section{CONCLUSION}

The publication of a volume dedicated to Kandinsky in a country where a president just came to power who had promised to give police "carte blanche to kill" and to do away with human rights, 80 years after the London protest exhibit, is another victory of the spiritual in art in the eternal struggle between the darkness and the light. 


\section{THE BAUHAUS AS INSPIRATION FOR CHINESE INNOVATION: REPORT FROM HANGZHOU, CHINA \\ Kiril Bolotnikov}

\section{ABSTRACT}

The China Design Museum's Bauhaus collection in Hangzhou, is not meant as a destination for foreign scholars. Instead, it's part of a push to emphasize homegrown innovation and inspire the future of Chinese design.

Keywords: Bauhaus. China. Innovation.

\section{RESUMO}

A coleção Bauhaus no China Design Museum in Hangzou não foi idealizada para consulta por parte de pesquisadores não-chineses. Antes, é parte de uma estratégia de se enfatizar inovação no país e inspirar o futuro do Design Chinês.

Palavras-chave: Bauhaus. China. Inovação.

The China Design Museum, which opened its doors this spring on a campus of the China Academy of Art (CAA) in Hangzhou, began its acquisition of some 7000 design artifacts earlier this decade. Several hundred were original Bauhaus pieces, and indeed, the China Daily reports that the "Bauhaus is the reason the China Design Museum was created in the first place."

Some have expressed uncertainty about a Chinese museum setting itself up as a go-to destination for Bauhaus scholars. But let there be no mistake: the CAA is not so much attempting to give the average museum-goer a

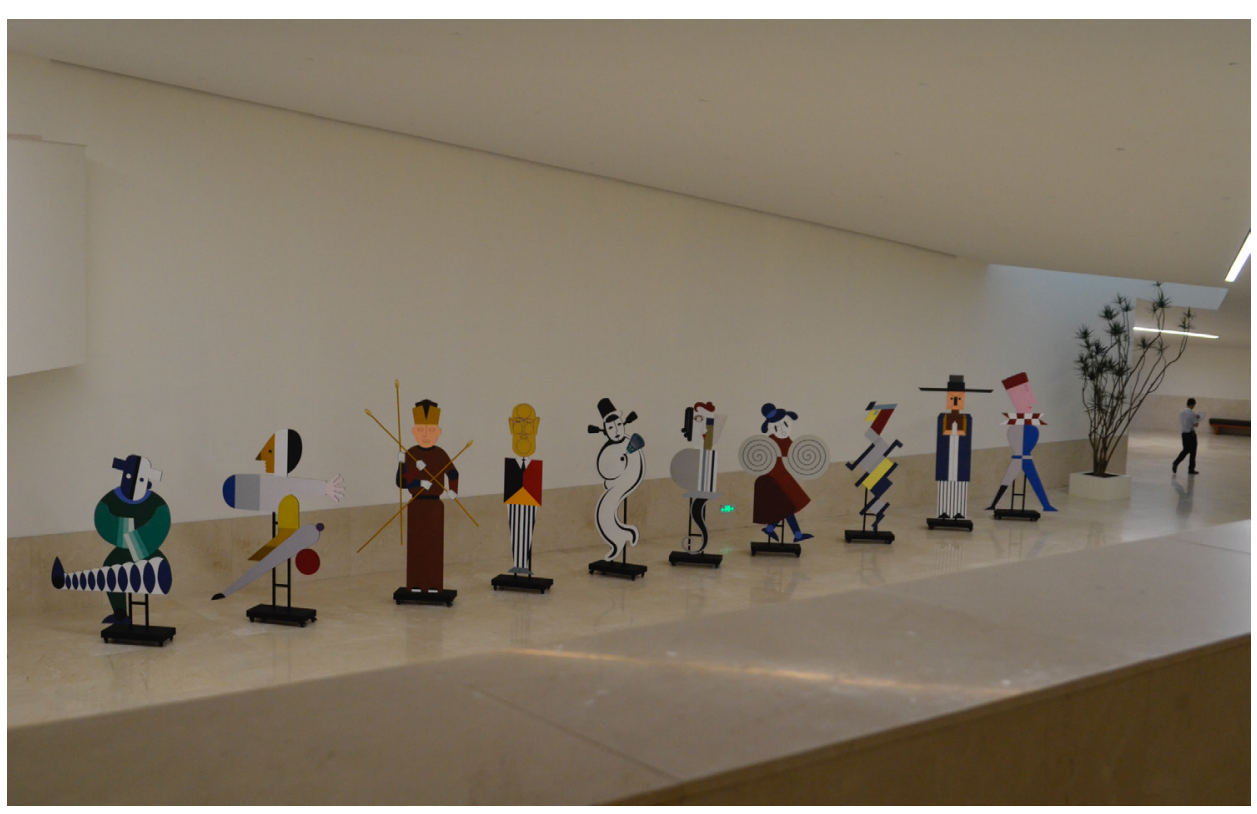
comprehensive understanding of the Bauhaus. Instead, it is using the Bauhaus as a starting point for the CAA's attempt to inspire innovation in a nation
Fig. I Lobby of the China Design Museum in Hangzhou. 
known for so long for its barely disguised copies and fake replicas of name-brand goods, for factories pumping out foreign designs rather than their own.

The most prominent exhibition, that of Bauhaus and closely related artifacts, is there to show how design innovation came in the most seemingly ordinary forms. That is, designs we don't look twice at today, the curators tell us, were in fact innovations when they were created 100 years ago, and have forever changed the way we interact with the objects around us. Accordingly, the glass cases are full of chairs, lamps, plates, kettles,

Fig. 2 The Gropius-designed faculty house shared by Kandinsky and Klee. doorknobs, wardrobes, and more, all designed by predecessors of the Bauhaus, its teachers, or its students. Even a small model of the faculty house shared by Kandinsky and Klee, as designed by Gropius, made the cut. As exciting as it was to reconsider the revolutionary aspects of these now-standard designs, I derived as much pleasure from seeing genuinely fascinated groups of Chinese tourists trailing knowledgeable docents from object to object.

It is conceivable that those who planned the museum and its acquisitions had Kandinsky in mind when they set about this enormous project. His landmark treatise Concerning the Spiritual in Art was translated and published in China in the 1980s, less than a decade after the Reform and Opening Up in the late 1970s. In its introduction, Kandinsky wrote, “...[E]ach period of culture produces an art of its own which can never be repeated. Efforts to

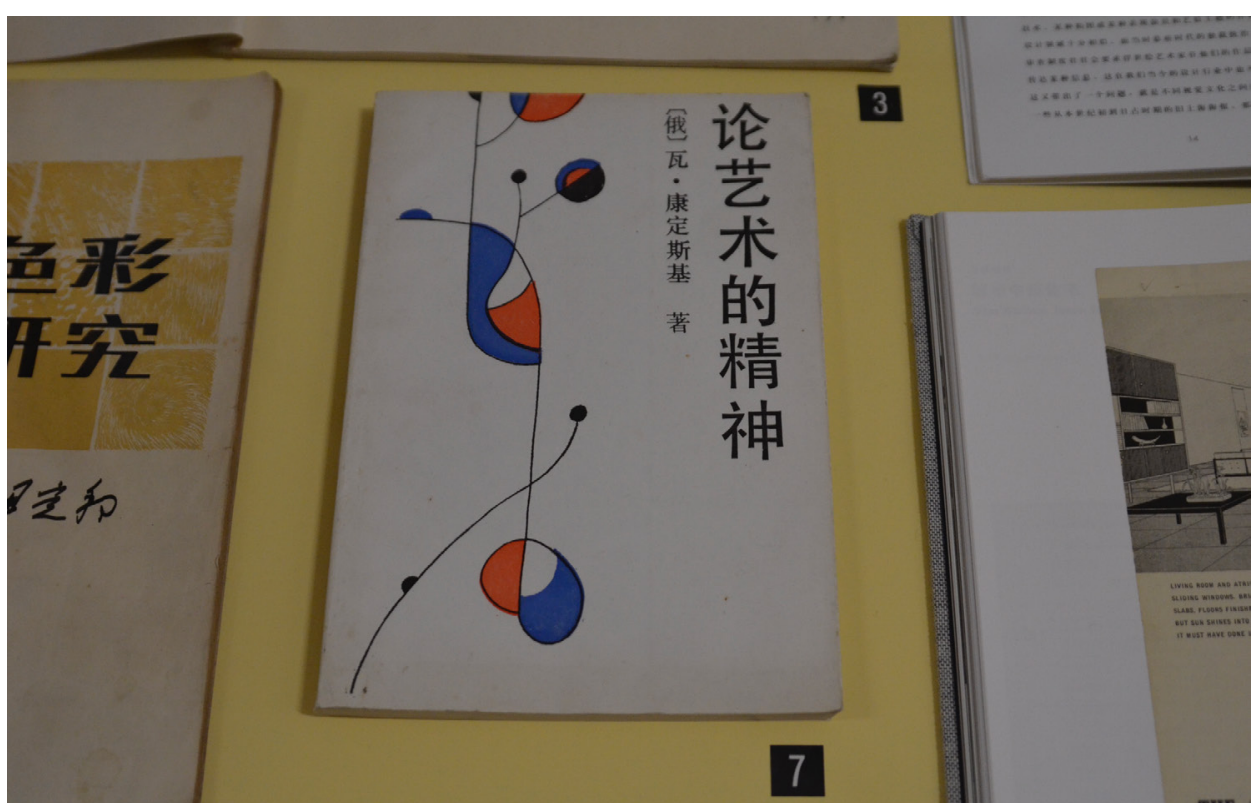
revive the art-principles of the past will at best produce an art that is stillborn." Though the museum is also funding research about the Bauhaus to strengthen its credentials, it has made no secret of the fact that its eye is

Fig. 3 The first Chinese edition of Kandinsky's Concerning the Spiritual in Art. 
ultimately focused on the coming period of Chinese art and design, not solely on the art principles of the Bauhaus past.

To the same extent that it does focus on the Bauhaus past, it focuses on the Chinese past: Shanghai Daily reports that the academy is currently in the process of collecting Chinese designs of the past hundred years, presumably to be shown in another permanent exhibition. The museum's opening ceremony

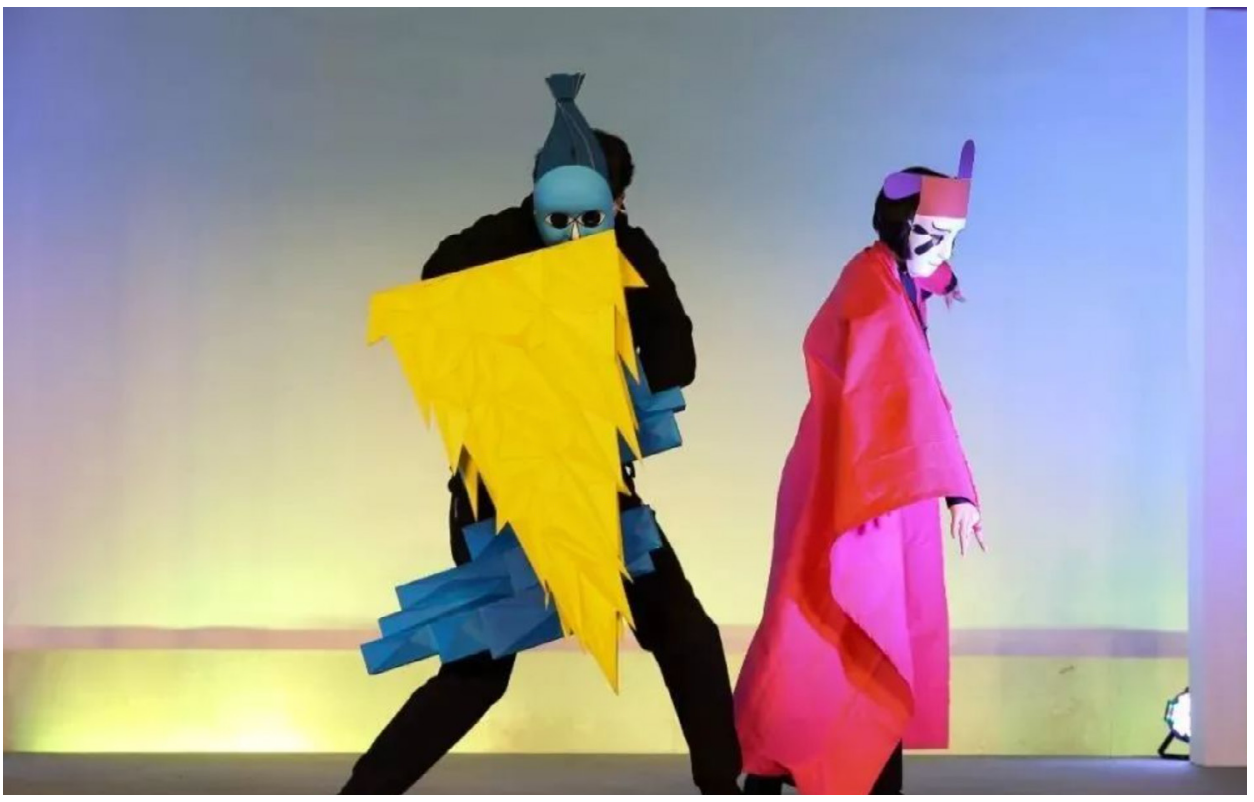
included a performance, in collaboration with the Goethe-Institut, of Oskar Schlemmer's "Figural Cabinet" - as a student research piece exploring the potential for dialogue with Song dynasty zaju (poetic dramas). And a timeline Schlemmer's "Figural Cabinet" at the opening ceremony. on a long wall just off the main exhibit placed both Western and Chinese cultural events. For instance, we see that the Bauhaus was founded in 1919, but just to the left of that particular marker, under "1917," the timeline notes that Cai Yuanpei, father of the modern Chinese education system, gave a speech entitled "Substituting Aesthetic Education for Religion." The intent is surely to draw attention to the nature of the adjacent trajectories of China and the West, in order to combat notions that Chinese thought is purely received wisdom devoid of innovation.

At the time of my visit in July, the existence of a temporary show entitled "Bauhaus Imaginista" told a further story in regards to the museum's refocusing the Bauhaus legacy with Chinese goals in mind. Curated in collaboration with Goethe-Instituts around the world to celebrate the centenary, it explored how the Bauhaus influenced local art and design respectively in each country, and how local art and design had in turn influenced local Bauhaus strains. The exhibit was composed of blocks of text, prints of grainy old black-and-white photos, tables of old publications, and occasional screens with informative videos, all emphasizing the ways in which Chinese artists, architects, and designers have collaborated with and built on Bauhaus design principles. It referred, for instance, to Chinese scholars who had studied outside the country in the 1930s and 1940s with this or that former Bauhaus teacher (Gropius, Mies van der Rohe), as well as to Gropius's commission to work with Chinese architects on Hua Tung University (a project abandoned when the Communists took over). 
However, as ought to be expected, the museum's collection of artifacts, as well as its presentation of both the permanent and temporary exhibitions, is decidedly apolitical. China was never going to be quite the place for an indepth understanding of the Bauhaus, at least not in the current political environment. The Bauhaus, its principles, its faculty, all of these were inherently socially revolutionary in a way that curators seem loath to address, hewing instead to a watered-down understanding of the Bauhaus as the instigators of a design revolution. Even entering the exhibit, the introduction reads, “... [T] he school developed an international modernist style and permeated various aspects of the daily lives of ordinary people," conveniently echoing Chinese Communist Party rhetoric about "the people" in a way that makes the exhibit socially relevant but leaves it politically correct.

It is important, accordingly, to understand that classifying this as a comprehensive retrospective would be a fallacy: if they are looking to the past innovations of the West, it is simply as encouragement for China's presumably surpassingly innovative future. It is worth noting that funding for the museum came at least in part from the Zhejiang provincial government. The emphasis on the Bauhaus and its innovations of a century ago

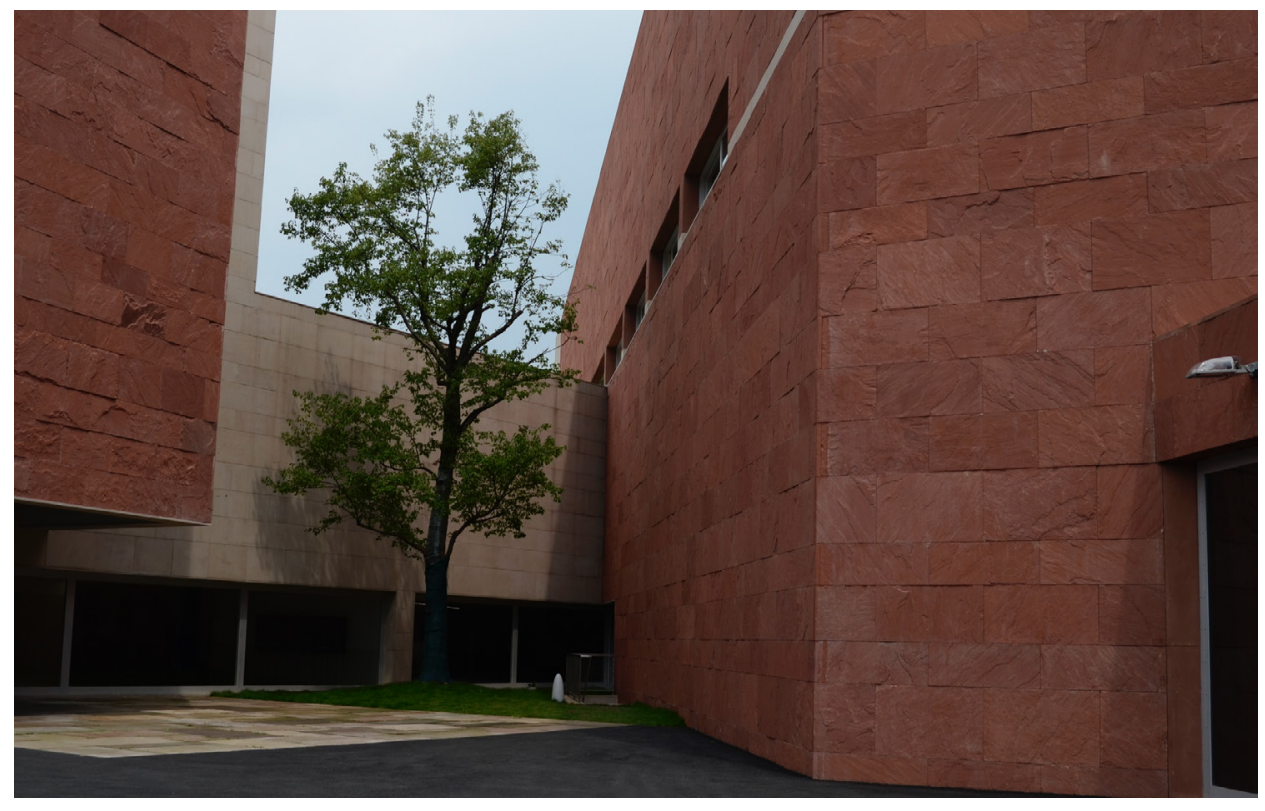
seems to be a concerted effort by the province to push its numerous factories in the direction of innovation rather than imitation - Zhejiang factories tend

Fig. 5 The front entrance of the China Design Museum. to be smaller, family-owned, and to produce for a domestic consumer base, working therefore with more autonomy than the large factories down south used by international companies looking for cheap labor. Far from trying to create the next Bauhaus, the CAA in founding this museum wants to encourage something far more homegrown. 


\title{
4. CONSIDERING KANDINSIKY'S CIRCLES:
}

\section{A PAINTER'S ADVENTURE OF THE MIND}

David Wiley

Visuals selected by Lissa Tyler Renaud

\begin{abstract}
A painter's inquiry and insights into the circle in Kandinsky's paintings, following his own delightful, intuitive thought process, informed by deep knowledge of art theory and art history.
\end{abstract}

Keywords: Kandinsky. Guggenheim. Jawlensky.

\section{RESUMO}

Questionamentos e intuições de um pintor sobre os círculos nos quadros de Kandinsky.

Palavras-chave: Kandinsky. Guggenheim. Jawlensky.

There is often a good deal of serendipity involved in adventures of the mind. When a series of mental events leading to a possibly meaningful conclusion occurs, it is not unusual for this conclusion to be dependent upon something unintended and unforeseen, just as the "accident" that happens in a painting may point the artist in a new and more fruitful direction. It was Aristotle's notion that genius is the rapid perception of the relationships between things. Although it seems incomplete, I have always liked this definition of genius. The practice of art is certainly a process of finding the relationships between things, physical and abstract, and using these relationships in a significant and moving way. The challenge for the artist is to harmonize and compose the parts.

During a trip to New York City I spent a few hours in the Guggenheim, mostly looking at the exhibition of Kandinsky paintings from his Paris period. As I gazed rapturously at these paintings, some of which I had never seen, my thoughts turned to earlier Kandinsky paintings. As I looked at the paintings, trying to regard them without prejudgment of any kind, they began to speak to me, they began trying to tell me something that I didn't understand and needed to understand. It was a fairly urgent message, it seemed to me, but one I simply could not decipher. Plato's saying that all knowledge is but remembrance came to mind. It was something I knew somewhere in my being, 


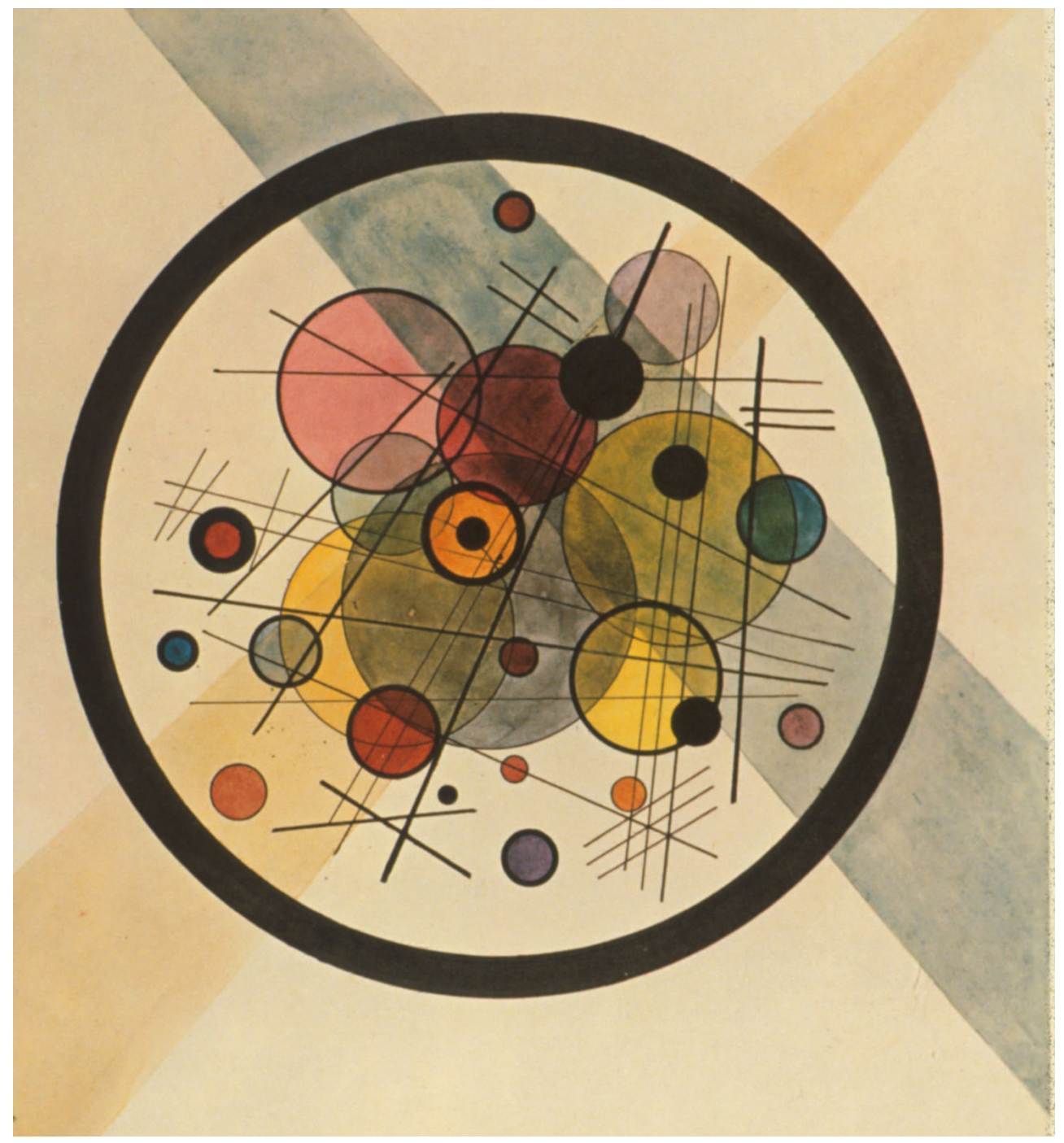

Fig. I Kandinsky, "Circles Within a

Circle," 1923

Fig. 2 Kandinsky, "Accent on Rose,"

and I was trying to drag it up through the smoke and mirrors and chaos of the subconscious. It didn't help to stare at the paintings and try to analyze them. What they were telling me had little to do with analysis. The more I tried to figure out what the voice was saying, the fainter it became.

As we left New York the next day I was still scouring my mind for an answer. It was annoying, like forgetting a familiar word or name. Shortly after we arrived in California I met up with my niece Gabey, who was nine months pregnant, and I remarked to her that she reminded me a little of Kandinsky, with her semispherical belly. This observation did not produce an answer to the question that had been nagging me persistently, but, as it turned out, the sight of Gabey's belly was a stepping stone, a station along the way in my mental treasure hunt.

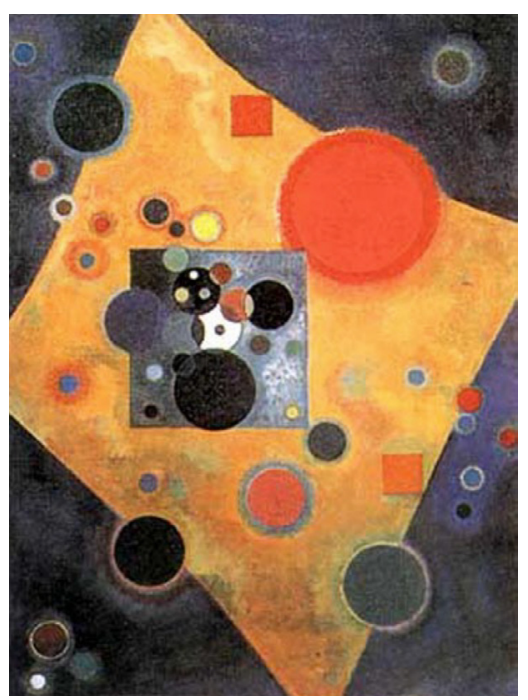




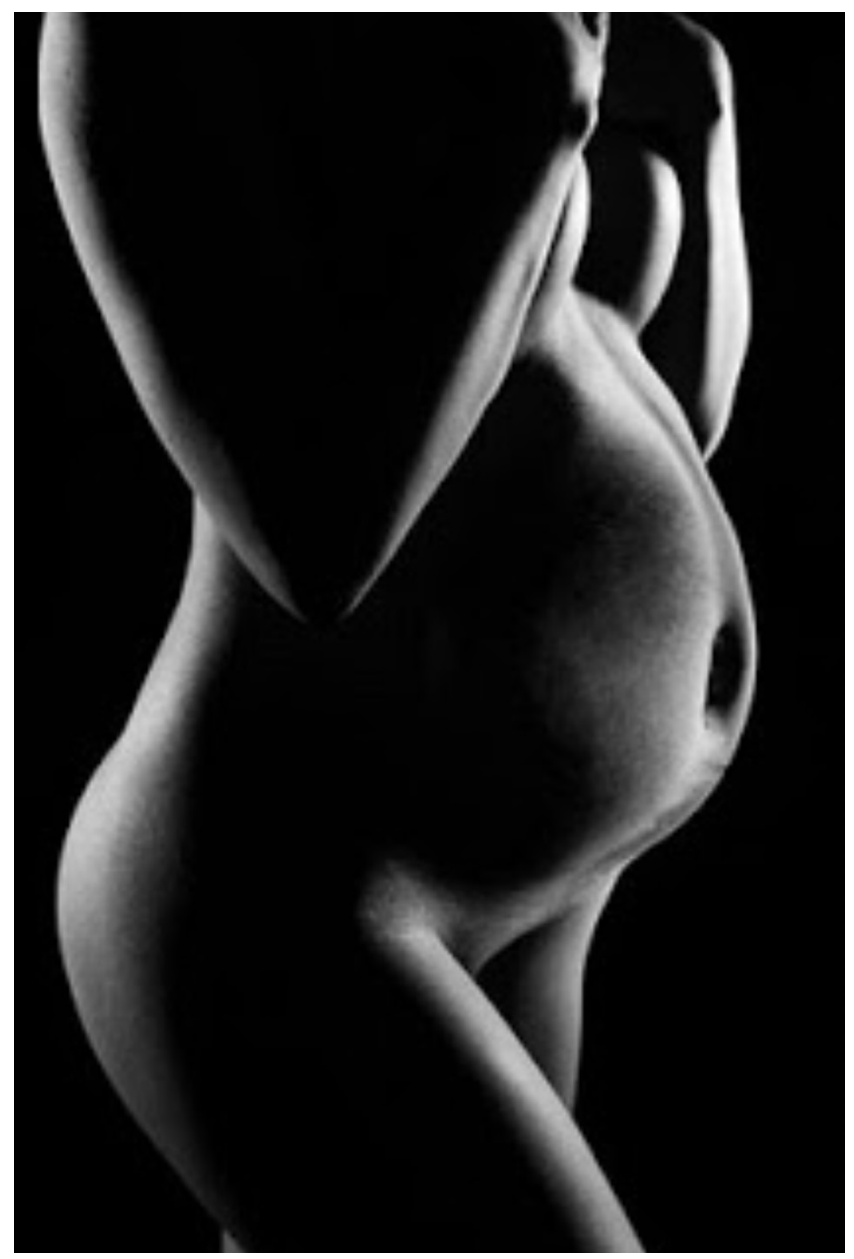

Fig. 3 Dean Farrell, Orcatek Photography

Fig. 4 Kandinsky, "Fixed Points,"

1942

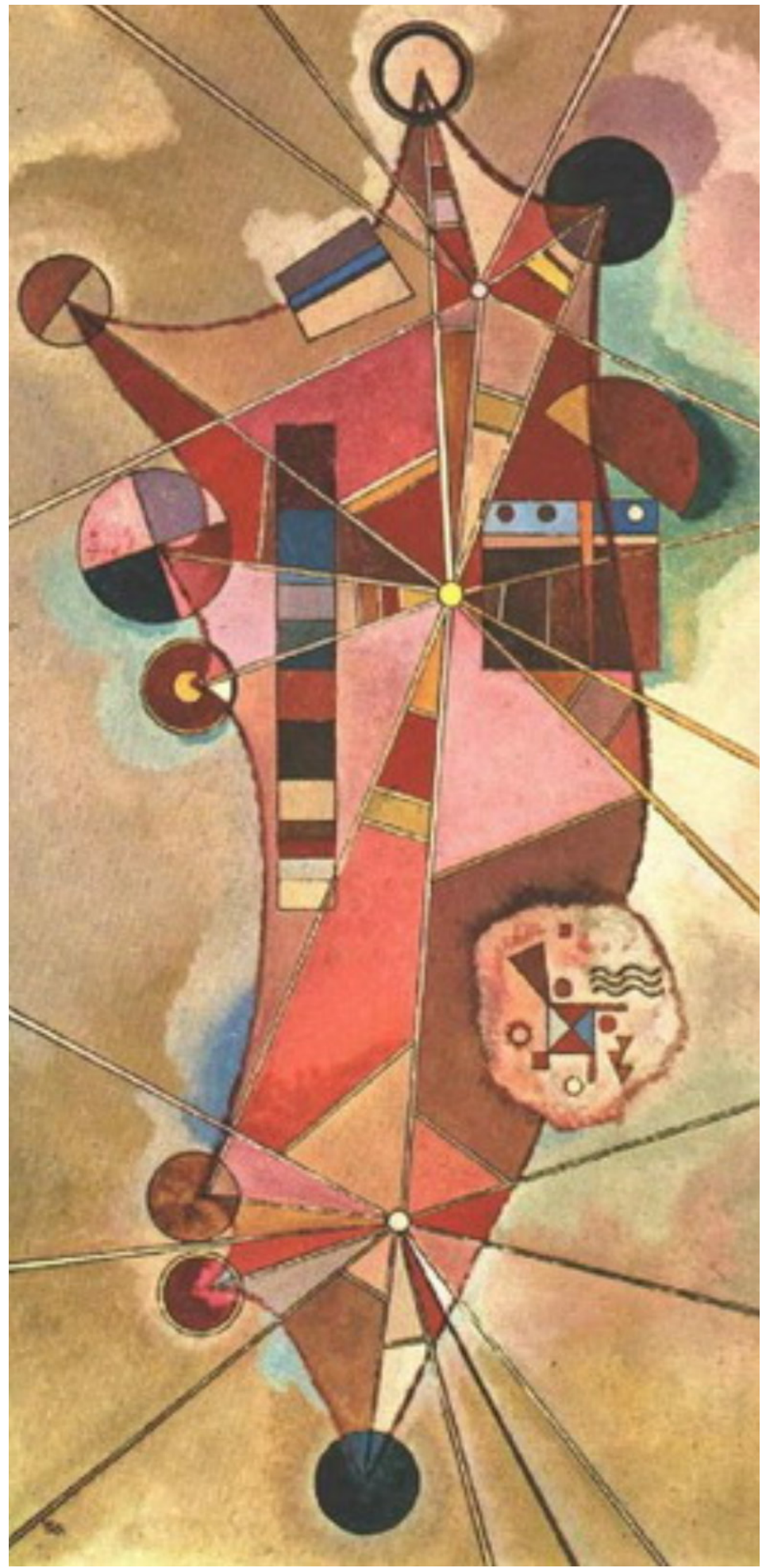




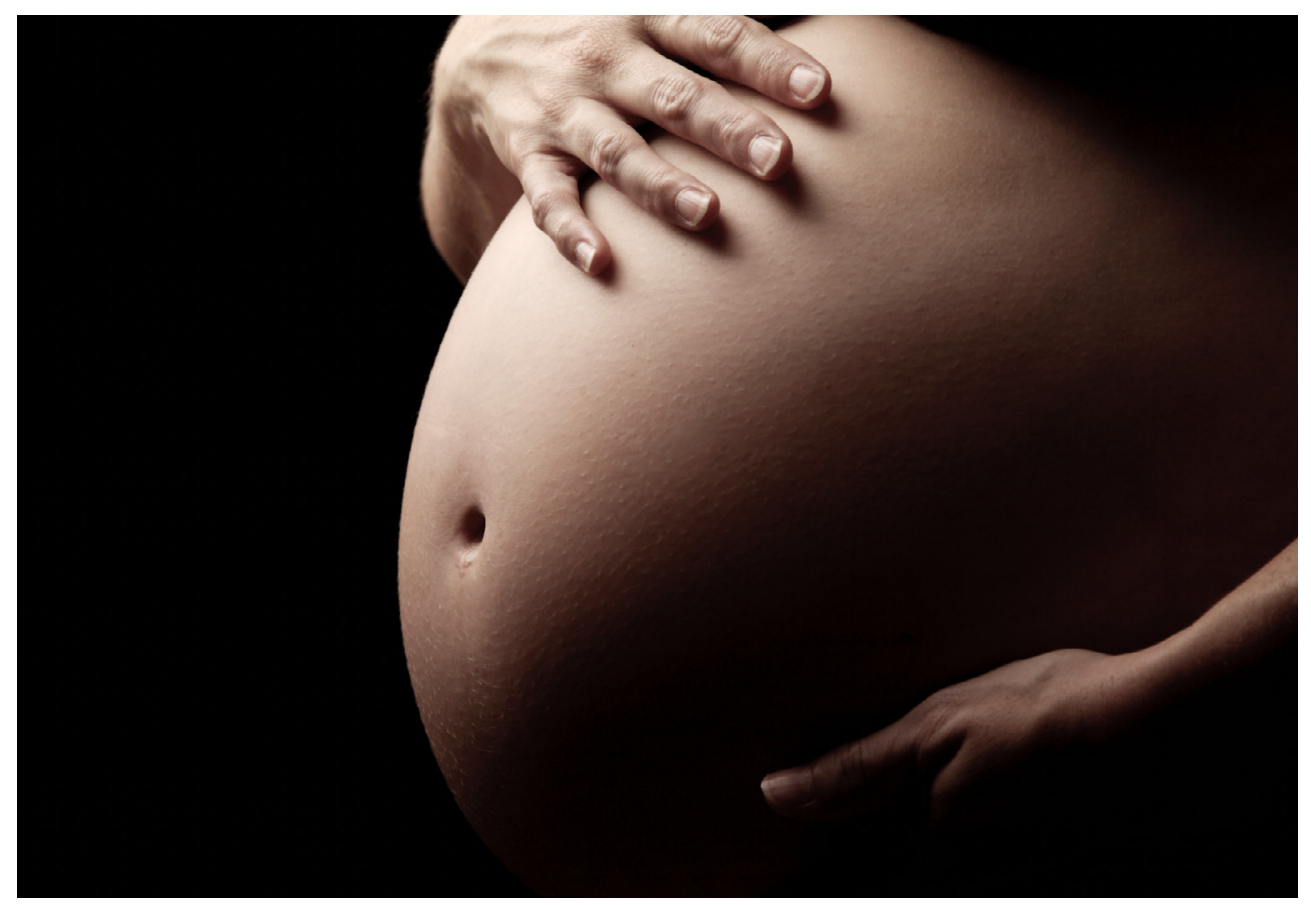

Fig. 5 [unattributed]

Fig. 6 Kandinsky, "Heavy Circles,"

1927

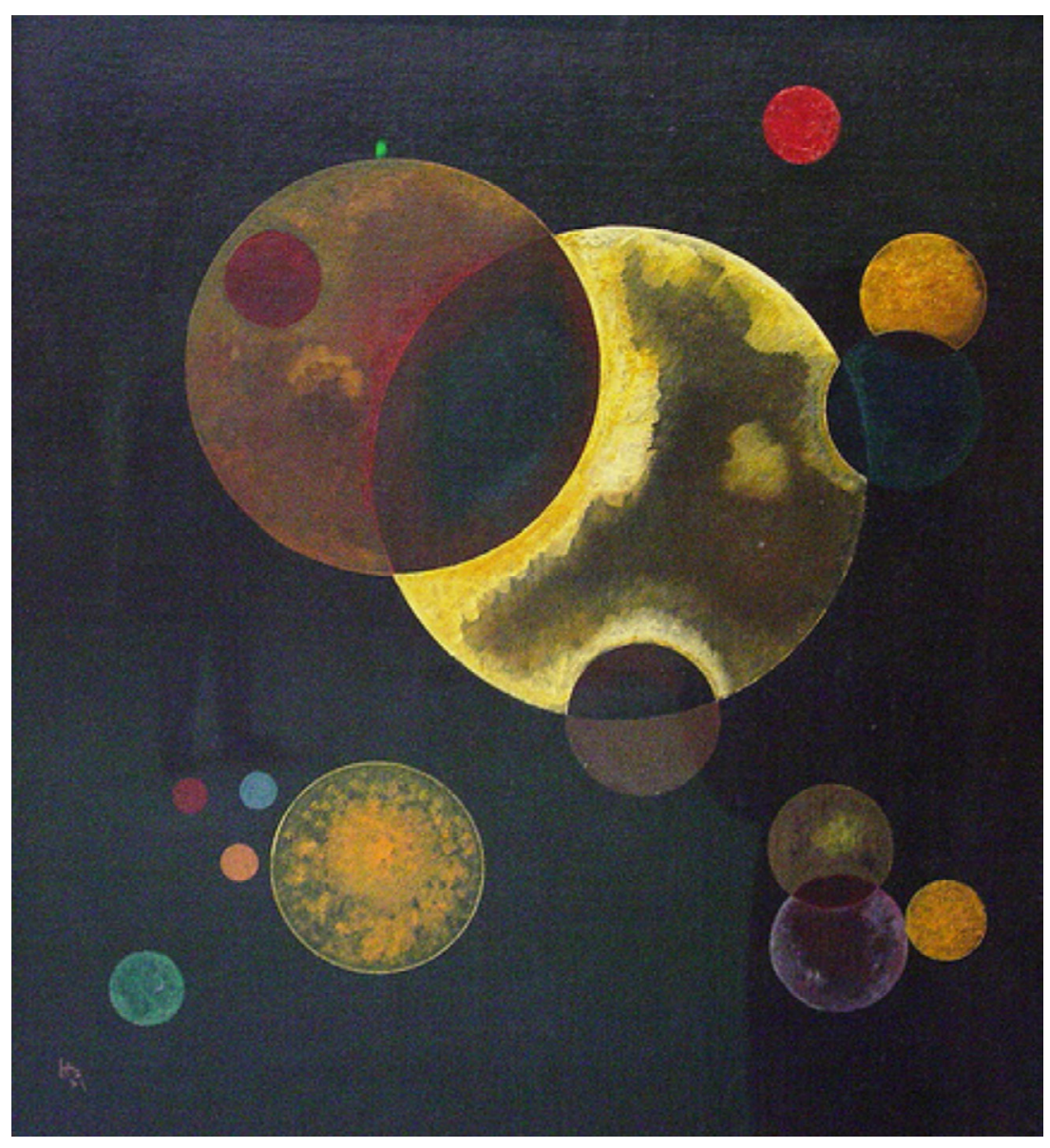


Two days later, as I was sitting in my studio thinking about Kandinsky again and trying in some way to resolve the matter that had been tormenting me for four days, my thoughts turned to another one of my favorite painters, Alexei Jawlensky, who, along with Kandinsky, Klee, and Feininger, was one of “The Blue Four." Then my thoughts went back eight years to my miraculous discovery of a large exhibition of Jawlensky paintings in a small museum at the edge of a

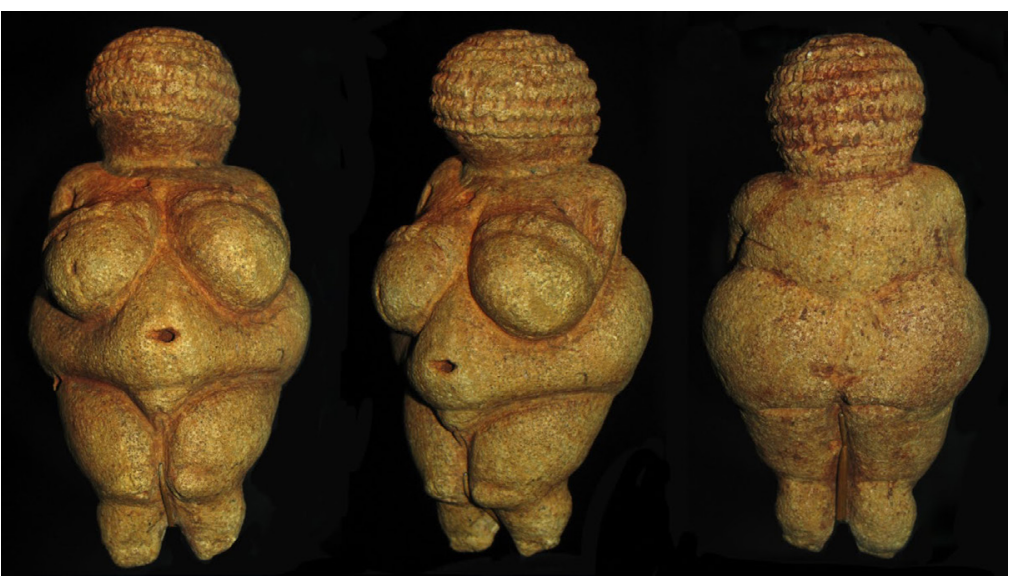
little medieval town on the Danube, about eighty miles from Vienna. My companion and I had taken a river excursion boat from a place called Krebs to the town at the end of the line. Here my memory failed me, not in the Platonic view, but in the normal human sense. Determined to get the answer to this question, at least, I found my Vienna guidebook and turned to the page where there was a graphic of that stretch of the Danube we had covered. I scanned the irregular line of the river, stopping at some of the historic sites along its banks, the castle where Richard Lion Heart had been imprisoned, and so on. Just before coming to Melk, the town where we had serendipitously found the Jawlensky exhibit, the town whose name I had forgotten, my eye stopped at another ancient place along the river, the village of Willendorf, just above Melk. Here a wealth of Neolithic artifacts has been uncovered, including the famous Venus of Willendorf, a 24,000-year old limestone sculpture of a rotund pregnant woman. I reflected that the Neolithic artists painted and sculpted according to what they understood was important. And one of the things that was very important to them was fertility. In the guide book there was a tiny drawing of the Venus, and as soon as I focused on it the proverbial light above my head turned on. All the pieces of the puzzle fell into place, as they say. What Kandinsky's

Fig. 7 "Venus of Willendorf"

Fig. 8 Kandinsky, "Around the Circle," 1940 paintings had been trying to tell me was that they were about fertility. Cosmic fertility no less.

It wasn't just the circles, which of course may represent many things, nor was it that the sphere is the most potent and fundamental of all symbols. It was the way Kandinsky's circles and triangles and swirls and trapezoids and trapeziums all intermingle in a three dimensional way, creating an impression of cosmic intercourse. Geometric or not, Kandinsky's highly symphonic compositions are bursting with energy and life.

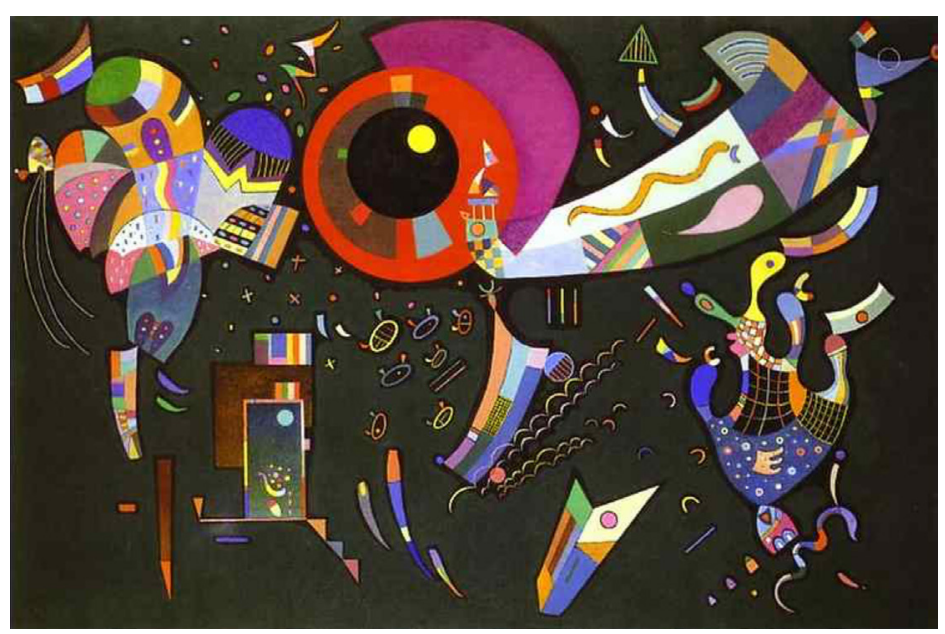


The urgency of the message, I believe, had to do with the fact that I am a painter, and of late my work has been going in a Kandinskyish direction, for reasons unknown. This little adventure of the mind, resulting in the eventual apprehension of "cosmic fertility," has given me a welcome concept to work with, the kind of concept that involves the simple, the obvious, the mysterious, and the complex.

As a coda to this business perhaps a theatrical production could be created based on the story. It could have Neolithic people making art and other things, cosmic scenes and events, triangles of every possible kind, and all known shades of color, each one making a sound of its own and emitting a fragrance different from all others.
Fig. 9 Kandinsky, stage set for "The Gnomes," Mussorgsky's Pictures at an Exhibition, 1928

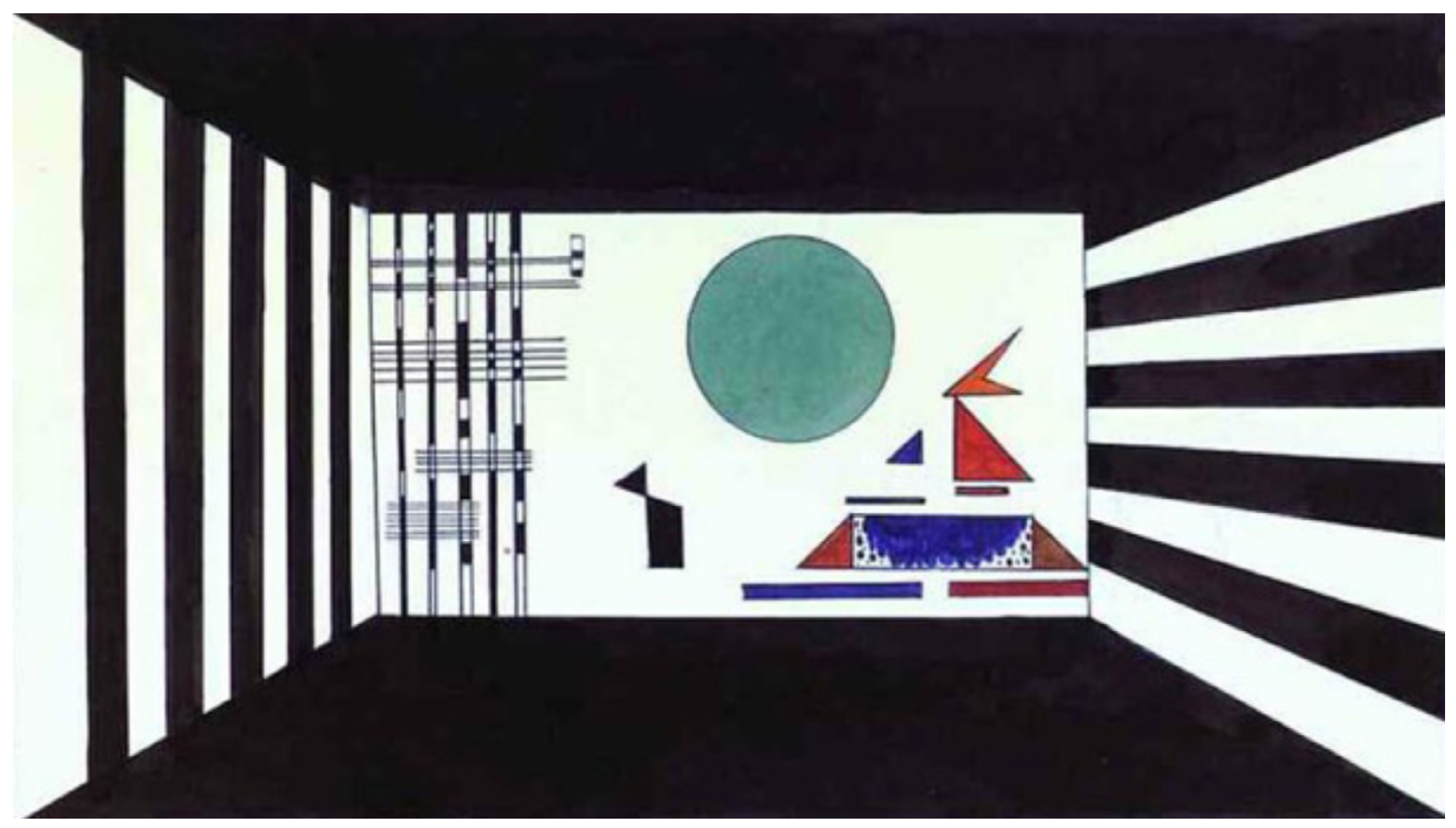




\title{
G. MATERIALS AND LINKS PORTFLOIO
}

Selected by Lissa Tyler Renaud

\begin{abstract}
A selection of materials and online links that add to our collective thinking about the beyond-painting profile of Kandinsky we are exploring in this special issue: on Acting, Architecture/Fashion, Theatre, Poetry, and Kandinsky in Contemporary Performance.
\end{abstract}

Keywords: Theatre. Architecture. Poetry. Performance.

\section{RESUMO}

Uma seleção de materiais e links que ampliam as considerações do que foi apresentado neste número sobre Kandinsky além da pintura: temos Kandinsky e atuação, arquitetura, moda, teaatro, poesia e na cena contemporânea.

Palavras-chave: Teatro. Arquitetura. Poesia. Performance.

\section{PAINTING AND ACTING; ARCHITECTURE AND FASHION}

HELEN MIRREN ON VASILY KANDINSKY AND ACTING

My special interest is in Kandinsky's approach to painting as it can be applied to acting and actor training.

In the video entitled "Helen Mirren on Vasily Kandinsky," world-renowned actress, Dame Helen Mirren, talks about painting in general and Kandinsky in particular (see link below). I am especially interested in her comments about the parallels between Kandinsky's process as a painter and hers as an actress.

The transcript of Dame Mirren's remarks follows.

Lissa Tyler Renaud

○

\section{HELEN MIRREN ON VASILY KANDINSTY}

Painting, actually, is what I love the most. Literally, paint on canvas, or paint on wood, or paint on anything. It's what gives me the most pleasure in my down time. It's great just to go into an art gallery - just ignore everything, and go to one painting. And just spend five or ten minutes with that painting. 
Unfortunately, I always like to look at paintings really close - the guards always get rather nervous when I'm in a gallery. I want to experience the painting as the painter did, and when you get into that world - you know, basically sort of this far away [gestures from her nose to extended arm] —you need to be that far away because that's where the painter was. Now I'm in his or her space, and I'm experiencing it the way they did, and I love that. I always feel I can feel the painter, feel the struggles and the thought or the anger or the joy or whatever it is. You know, my dad very much wanted to be a painter - he was actually a cab driver - he loved painting, and I, actually I own a couple of his paintings - they're not very good, they're sort of, you know, copies of, of French Impressionist style. But he, um, he loved painting, and I think I inherited that to a certain extent from him. And my, um, entertainment as a young girl was never to go to pop concerts or that sort of thing. I used to love to go to the local art gallery and just walk around.

Brilliantly, you [the interviewer] put me in front of my favorite artist, Kandinsky. And they are my lovely friends [referring to the Kandinsky paintings on the gallery walls]. You know, it's not often that you'll see four magnificent Kandinskys like that, in a row in a museum - that's an amazing thing to see. There's a sense of chaos, and randomness, and, and like the universe, you know, it's random but it's organized, in this incredible contradiction. And when I first saw a Kandinsky, I assumed that it was just improvisational, it was just instinctive and improvisational, and wild, and, and of the moment - I loved it for that reason. And it wasn't until I went to see a retrospective of Kandinsky's that I learned that actually his work is incredibly worked out and- not "controlled," but, um, you know, it's far from improvisation. It's, it's a very thought about, constructed image. You know, that's the connection with my art. It's, you have... it's very technical, you know. Whether it's on the stage or on film, it's highly technical. But within this extreme form - technical form - you have to give an impression of improvisation, and of naturalness, and of it being invented there and then, in the moment. And to me that was perfectly what Kandinsky represents as an artist. There is that process that Francis Bacon describes so well, of learning what he calls "the good accident." And that's very much a part of what I do, is learning the good accident in acting. As an actor, you know, I'm always very jealous of painters, and indeed, of singers. Because a song can travel straight into the heart, the way a painting can. What I do has to be processed through the brain: people have to follow the story; it has to make sense. A song, just the note of a song, can make you feel something; likewise, a painting can do the same thing... 
Filmed by Lost and Found Films for MoMA

https://www.youtube.com/watch?v=0_YDrJoUe8s

$\odot$

\section{NIGERIA: BAUHAUS ARCHITECTURE AND KANDINSKY FASHION} INTRODUCTION

Lissa Tyler Renaud

The year 2019 will be the $100^{\text {th }}$ anniversary of the opening of the Bauhaus, and for the occasion the Goethe-Institut has teamed up with the Bauhaus, the House of World Cultures, and various other local and international organizations to arrange an enormous celebration. Even leading up to next year's centenary, beginning in March of this year, there have already been a range of events planned that point up the fact that the Bauhaus, which was closed down in 1933, had its own diaspora: teachers, students, as well as the Bauhaus teachings and aesthetic made their way around the world. From this perspective, by now, the Bauhaus is no longer so much a Germany-specific phenomenon, but instead has become a kind of international handshake, a way of thinking and seeing that we can find in many parts of the world. Events have been scheduled in Morocco, China, Russia, the United States, Japan, Russia, Brazil, India, and Nigeria.

Goethe-Institut Nigeria in Lagos hosted a film and symposium on Nov. 23-24, just as this Special Issue was "going to press."

Bauhaus structures have been apparent in Nigeria at least since the 1960s, through architect Arieh Sharon. See more about the Bauhaus in Africa here: http://archive.diarna.org/site/detail/public/174/

○

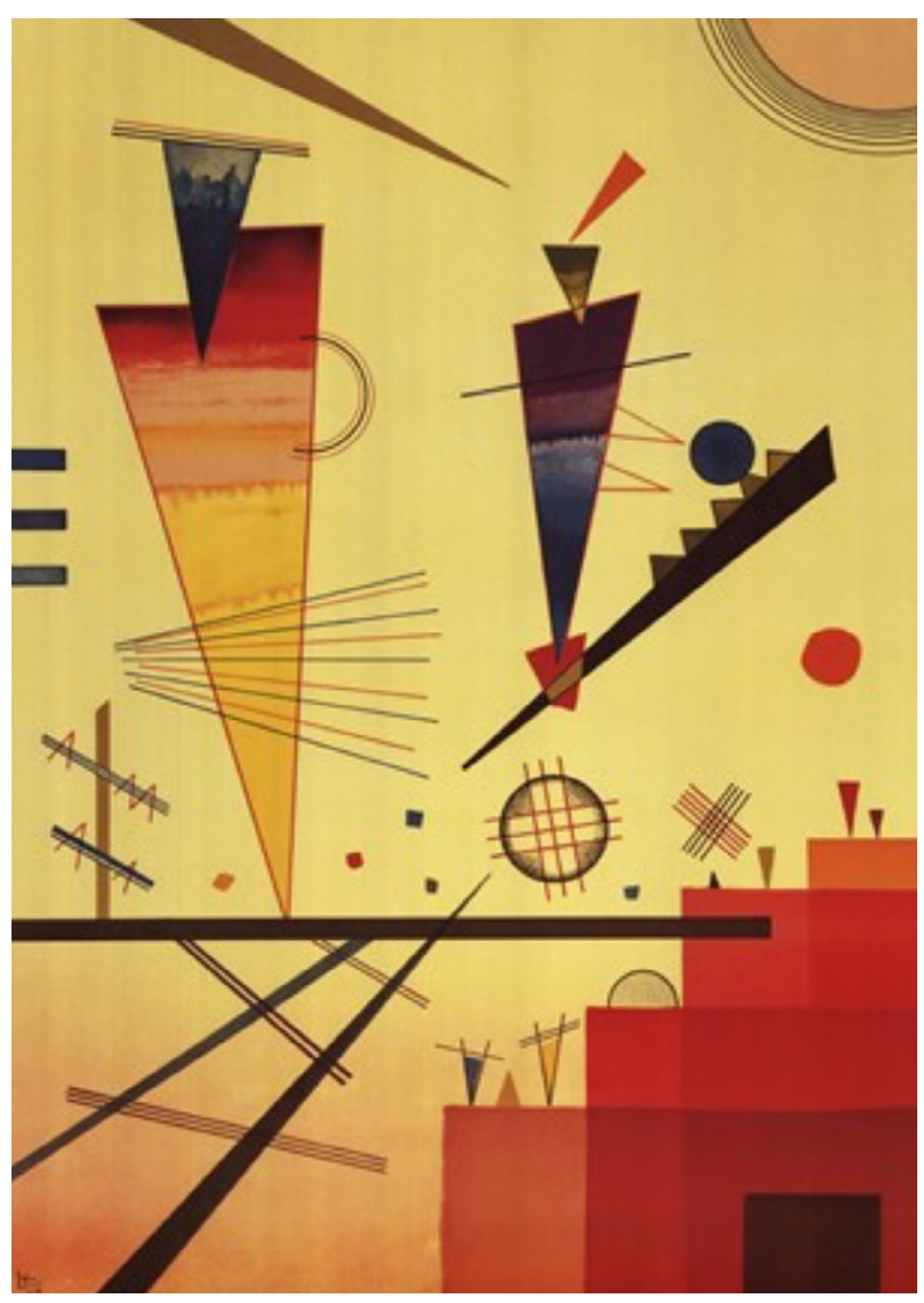

At the link on the right, we can see a creative hybrid of Kandinsky's Bauhaus work and an African visual sensibility, manifested in Nigerian fashion. The following collection is a perceptive interpretation of his "Structure Joyeuse" of 1926 (at right). 
Fashion brand CeCe has launched its latest collection titled 'Kandinsky'. The collection features the brand's interpretation of 'Structure Joyeuse' which translates to the use of shapes and colours.

The brand draws inspiration from Wassily Wassilyevich Kandinsky, a Russian painter and art theorist who painted one of the first recognised purely abstract works. Structure Joyeuse, one of Wassily's abstract works in 1926, is the focus inspiration for this collection. They use a variety of shapes, structures and colours in the collection... His works all had a [specific] use of colour in trying to express himself, which they have incorporated in their latest collection. https://www.fashionghana.com/site/nigerian-fashion-brand-cece-presents-thelook-book-for-the-kandinsky-collection/

$\odot$

\section{THEATRE AND POETRY}

1. The Yellow Sound: An unstageable composition? Technology, modernism and spaces that should-not-be

Geraint Darcy

http://people.brunel.ac.uk/bst/voli2/geraintdarcy/geraintdarcy.pdf

2. Between Text and Image in Kandinsky's Oeuvre: A Consideration of the Album Sounds

Christopher Short

https://www.tate.org.uk/download/file/fid/7402

\section{KANDINSKY IN CONTEMPORARY PERFORMANCE}

1. Bauhaus Mind. Okus Dance, Belgium. 2018

http://www.okus.be/visuals/bauhaus

2. Yellow Sound. National University of Singapore-Yale University (Yale-NUS College). 2016

https://www.youtube.com/watch? $==f P R G u Q b X w s$ 
3. Yellow Sound2: Homage to Kandinsky. Sound-light installation, Berlin, 2012 https://www.youtube.com/watch?v=WtuTAUlKMkE

4. The Yellow Sound. (One of three world premières.) Music by Frank Zappa. Bavarian State Ballet. 2014

https://www.youtube.com/watch?v=HDUFYCj9wZM 